Original article

\title{
Synthesis and biological evaluation of novel substituted pyrrolo[1,2-a] quinoxaline derivatives as inhibitors of the human protein kinase CK2
}

\author{
Jean Guillon ${ }^{\mathrm{a}, \mathrm{b}, *}$, Marc Le Borgne ${ }^{\mathrm{c}}$, Charlotte Rimbault ${ }^{\mathrm{a}, \mathrm{b}}$, Stéphane Moreau ${ }^{\mathrm{a}, \mathrm{b}}$, \\ Solène Savrimoutou ${ }^{\mathrm{a}, \mathrm{b}}$, Noël Pinaud ${ }^{\mathrm{d}}$, Sophie Baratin ${ }^{\mathrm{a}, \mathrm{b}}$, Mathieu Marchivie ${ }^{\mathrm{a}, \mathrm{b}}$, \\ Séverine Roche ${ }^{\mathrm{a}, \mathrm{b}}$, Andre Bollacke ${ }^{\mathrm{e}}$, Adali Pecci ${ }^{\mathrm{f}}$, Lautaro Alvarez ${ }^{\mathrm{g}}$, Vanessa Desplat ${ }^{\mathrm{a}, \mathrm{b}}$, \\ Joachim Jose ${ }^{\mathrm{e}}$ \\ ${ }^{a}$ Université Bordeaux Segalen, Pharmacochimie, FRE 3396, F-33000 Bordeaux, France \\ ${ }^{\mathrm{b}}$ CNRS, Pharmacochimie, FRE 3396, F-33000 Bordeaux, France \\ ${ }^{\mathrm{C}}$ Université de Lyon, Université Lyon 1, Faculté de Pharmacie, ISPB, EA 4446 Biomolécules, Cancer et Chimiorésistances, SFR Santé Lyon-Est CNRS UMS3453 \\ - INSERM US7, 8 avenue Rockefeller, F-69373 Lyon Cedex 8, France \\ d ISM, CNRS UMR 5255, Université de Bordeaux, 351 cours de la Libération, F-33405 Talence cedex, France \\ e Institut für Pharmazeutische und Medizinische Chemie, Westfälische Wilhelms-Universität Münster, Hittorfstraße 58-62, 48149 Münster, Germany \\ ${ }^{\mathrm{f}}$ Departamento de Química Biológica and IFIBYNE (CONICET-UBA), Facultad de Ciencias Exactas y Naturales, Universidad de Buenos Aires, Pabellón 2, \\ Ciudad Universitaria, C1428EGA Buenos Aires, Argentina \\ ${ }^{\mathrm{g}}$ Departamento de Química Orgánica and UMYMFOR (CONICET-UBA), Facultad de Ciencias Exactas y Naturales, Universidad de Buenos Aires, Pabellón 2, \\ Ciudad Universitaria, C1428EGA Ciudad de Buenos Aires, Argentina
}

\section{A R T I C L E I N F O}

\section{Article history:}

Received 9 February 2013

Received in revised form 22 April 2013

Accepted 25 April 2013

Available online 3 May 2013

\section{Keywords:}

Pyrrolo[1,2-a]quinoxaline

Protein kinase CK2

Antiproliferative activity

Synthesis

\begin{abstract}
A B S T R A C T
Herein we describe the synthesis and properties of substituted phenylaminopyrrolo[1,2-a]quinoxalinecarboxylic acid derivatives as a novel class of potent inhibitors of the human protein kinase CK2. A set of 15 compounds was designed and synthesized using convenient and straightforward synthesis protocols. The compounds were tested for inhibition of human protein kinase $\mathrm{CK} 2$, which is a potential drug target for many diseases including inflammatory disorders and cancer. New inhibitors with $\mathrm{IC}_{50}$ in the microand sub-micromolar range were identified. The most promising compound, the 4-[(3-chlorophenyl) amino]pyrrolo[1,2-a]quinoxaline-3-carboxylic acid 1c inhibited human CK2 with an $\mathrm{IC}_{50}$ of $49 \mathrm{nM}$. Our findings indicate that pyrrolo[1,2-a]quinoxalines are a promising starting scaffold for further development and optimization of human protein kinase CK2 inhibitors.
\end{abstract}

(c) 2013 Elsevier Masson SAS. All rights reserved.

\section{Introduction}

Protein kinase CK2, formerly known as Casein Kinase 2, is a ubiquitous eukaryotic serine/threonine protein kinase. CK2 is a highly pleiotropic enzyme which catalyzes the transfer of terminal phosphate from ATP or GTP to various proteins implicated in a wide variety of cell functions. The catalytic subunits of CK2 (alpha and/or alpha') are constitutively active either alone or in combination with the regulatory beta-subunits to give a heterotetrameric protein. A third isoform of the catalytic subunit, designated CK $2 \alpha^{\prime \prime}$, was discovered more recently [1] and only very limited information is

\footnotetext{
* Corresponding author. Université Bordeaux Segalen, Pharmacochimie, FRE 3396, F-33000 Bordeaux, France. Tel.: +33 5575716 52; fax: +33 557571352 E-mail address: jean.guillon@u-bordeaux2.fr (J. Guillon).
}

available. Since its discovery in 1954 by Burnett and Kennedy [2], the activity of CK2 in physiological and pathological processes has been largely studied [3-5], particularly in cell proliferation and apoptosis. Overexpression of CK2 creates a favorable environment for tumor development. For example CK2 is involved (i) to promote abnormal pro-survival signals, (ii) to support neovascularization, (iii) to potentiate MDR phenotypes and (iv) to upregulate DNA repair. To resume the impact of CK2 on cancer development, recent works demonstrated that CK2 regulates multiple oncogenic pathways such as EGFR pathways (JAK/STAT, MAPK...), Cdc37/HSP90 pathway, Akt pathway (PTEN, PI3K...) [6,7]. Because of its prosurvival functions and its structural features, a considerable amount of additional works have been devoted to know its druggability [8]. CK2 has now emerged as a relevant therapeutic target for the treatment of cancer (e.g. prostate, mammary gland, 
lung, kidney, hematologic malignancies) [9]. Indeed, diverse strategies are developed to target CK2 [10], and to synthesize highly specific, selective and cell-permeable inhibitors. Most of them are directed toward the ATP binding site, and belong to (i) coumarins (ellagic acid), (ii) polyhalogenated benzimidazoles (TBB), (iii) anthraquinones (emodin), (iv) pyrazolotriazines, (v) indoloquinazolines (IQA) and naphthyridines and related (CX-4945, CX-5011) (Fig. 1) [11]. Pre-clinically, CX-4945 demonstrated single agent potency in suppressing xenograft tumor growth. The studies in BT474 breast cancer and BxPC-3 pancreatic xenografts showed robust antitumor activity including partial and complete regression of CX4945. These promising results in safety, pharmacokinetics and efficacy studies led to the clinical evaluation of CX-4945 [12].

The pyrrolo[1,2-a]quinoxaline heterocyclic framework constitutes the basis of an important class of compounds possessing interesting biological activities. These compounds have been reported to serve as key intermediates for the assembly of several heterocycles including antipsychotic agent [13], anti-HIV agent [14], adenosine $A_{3}$ receptor modulator [15], antiparasitic agents [16-20], and antitumor agents [21,22]. In this last field, the discovery and development of novel therapeutic agents are one of the most important goals in medicinal chemistry.

Recently, we have designed and developed a series of new interesting antiproliferative substituted pyrrolo[1,2-a]quinoxalines [23-25]. Thus, taking into account our experience in the field of the synthesis of new bioactive heterocyclic compounds based on our pyrrolo[1,2-a]quinoxaline heterocyclic core [16-20,23-25], we used the pyrrolo[1,2-a]quinoxaline moiety as a template for the design of new isosteres of the CK2 inhibitors CX-4945 and CX-5011 in which the pyrrolo[1,2-a]quinoxaline nucleus is substituted in different positions by a carboxylic acid function and a 3-substituted aniline in comparison with the reference compounds (Fig. 2). The 3chloroaniline and 3-ethynylaniline motifs were also conserved in our subsequent molecules in analogy with these reference derivatives CX-4945 and CX-5011. Our new synthesized compounds were then tested for inhibition of human protein kinase CK2. The antiproliferative profile of the most potent CK2 inhibitors 1 was then evaluated in vitro against a panel of four leukemic cell lines: U937, K562, Jurkat and MV-4-11. Moreover, to determine their respective cytotoxicity, the new pyrrolo[1,2-a]quinoxaline derivatives were tested on activated human peripheral blood mononuclear cells. Finally, a preliminary molecular modeling study was carried out to enlighten the mechanism of action implicating binding of pyrroloquinoxalines to the ATP-binding CK2 pocket by using X-ray crystal structure results obtained for compound cX-4945.

\section{Chemistry}

The synthesis of the (3-substituted-phenyl)aminopyrrolo[1,2-a] quinoxaline derivatives $\mathbf{1 a}-\mathbf{n}$ was accomplished from commercially available 3-methyl-2-quinoxalinol, from various substituted $1 H$-pyrrole-2-carboxylic acid alkyl esters, or from various 2nitroanilines via their respective lactames $\mathbf{2 a}-\mathbf{f}$ (Schemes 1-4).

The lactame 2a was prepared in two steps by treatment of commercially available 3-methyl-2-quinoxalinol with phosphorus oxychloride leading to the chloro derivative $\mathbf{3}$ following by condensation with ethyl bromopyruvate in dry ethanol (Scheme 1) [24]. The preparation of the $N$-aryl pyrrole 4 was obtained by nucleophilic substitution of the diethyl pyrrole-2,3-dicarboxylate 5, previously prepared according to the method of Röder et al. [26], with 2-fluoronitrobenzene using cesium carbonate as the base in refluxing DMF solution (Scheme 1) [24,25]. Reduction of the nitro moiety of $\mathbf{4}$ with iron in hot glacial acetic acid produced the spontaneous ring closure onto the ester to afford the desired tricyclic pyrrolo[1,2-a]quinoxaline $\mathbf{2 b}$ through a one-pot reduction-cyclization step [24,25]. Similar substitution of commercially the methyl pyrrole-2-carboxylate with various ethyl fluoro-nitrobenzenecarboxylate led to the methyl 1-(4or 5-ethoxycarbonyl-2-nitrophenyl)pyrrole-2-carboxylates $\mathbf{6 a , b}$. Refluxing compounds $\mathbf{6 a}, \mathbf{b}$ in acetic acid with iron powder also gave lactames $\mathbf{2 c , d}$. The synthesis of lactame 2 e was achieved from 2amino-3-nitrobenzoic acid according to two pathways. First, refluxing 2-amino-3-nitrobenzoic acid in thionyl chloride gave the corresponding acid chloride, which was treated with ethanol to give ester 7 in $85 \%$ yield $[27,28]$. The Clauson-Kaas reaction of 7 with 2,5dimethoxytetrahydrofuran (DMTHF) in acetic acid gave the pyrrolic derivative 8 in $64 \%$ yield. The second pathway involved at first the preparation of the 3-nitro-2-pyrrol-1-ylbenzoic acid $\mathbf{9}$ according to the Clauson-Kaas reaction. This acid $\mathbf{9}$ was then esterified by treatment with thionyl chloride in ethanol leading to ester 8 [29]. The resulting 1-(2-nitrophenyl)pyrrole ester intermediate $\mathbf{8}$ was subsequently reduced into the attempted 1-(2-aminophenyl)pyrrole ester 10 using a sodium borohydride-copper(II) sulfate in ethanol at room temperature according to the conditions described by Yoo and<smiles>O=c1oc2c(O)c(O)cc3c(=O)oc4c(O)c(O)cc1c4c23</smiles><smiles>Cc1cc(O)c2c(c1)C(=O)c1cc(O)cc(O)c1C2=O</smiles><smiles>Brc1c(Br)c(Br)c2[nH]nnc2c1Br</smiles>

TBB<smiles>O=C(O)Cc1c2ccccc2n2c1[nH]c(=O)c1ccccc12</smiles><smiles>C#Cc1cccc(Nc2nc3cc(C(=O)O)ccc3c3cncnc23)c1</smiles><smiles>CC(=O)Nc1cccc(Nc2nc(Nc3ccccc3)n3ncc(C#N)c3n2)c1</smiles><smiles>CC(C)(C)OC(=O)c1ccc2c(c1)nc(Nc1cccc(Cl)c1)c1ccncc12</smiles>

Fig. 1. Structure of ellagic acid, emodin, TBB, IQA, pyrazolotriazine derivative, CX-4945 and CX-5011. 


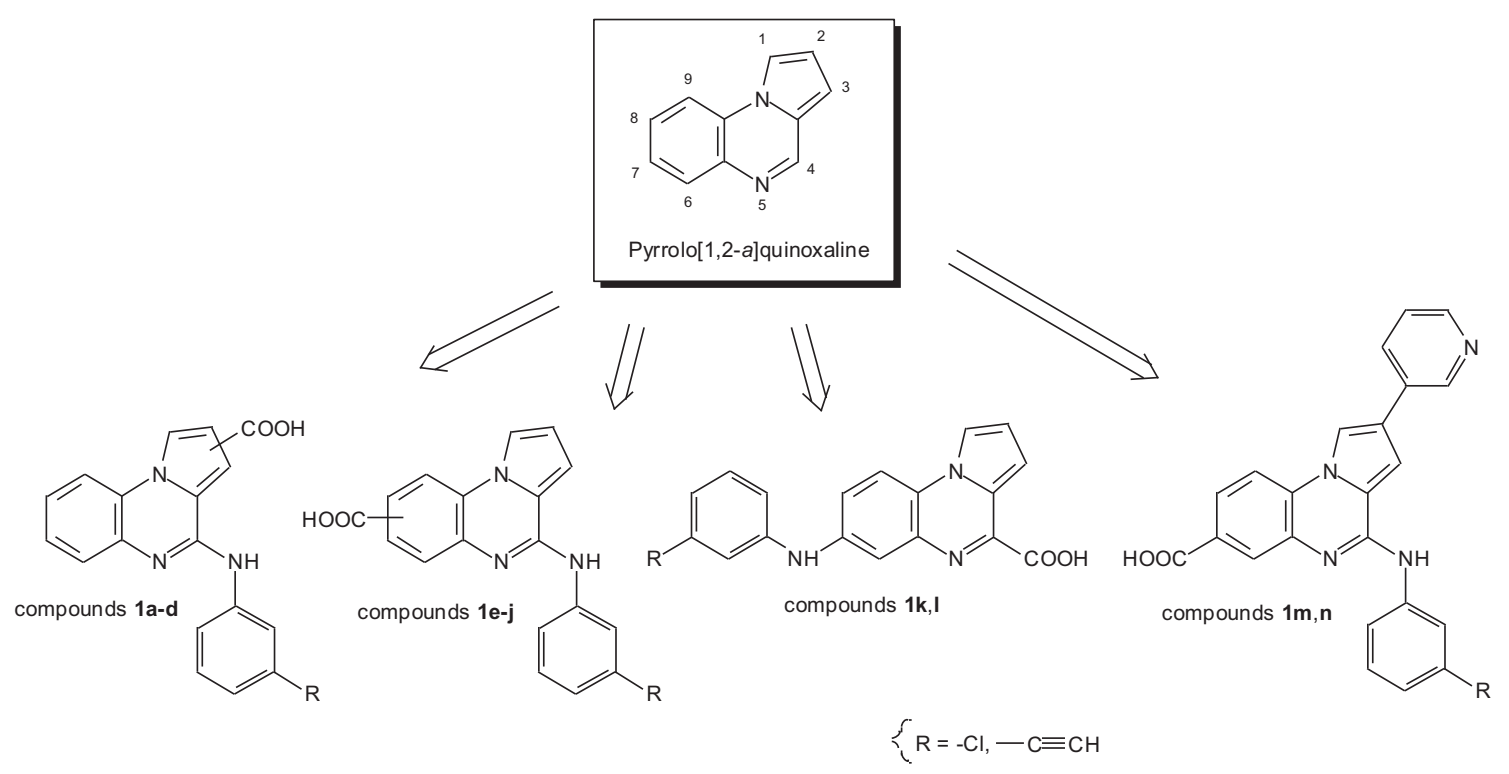

Fig. 2. General structures of new synthesized pyrrolo[1,2-a]quinoxaline derivatives 1a-n.
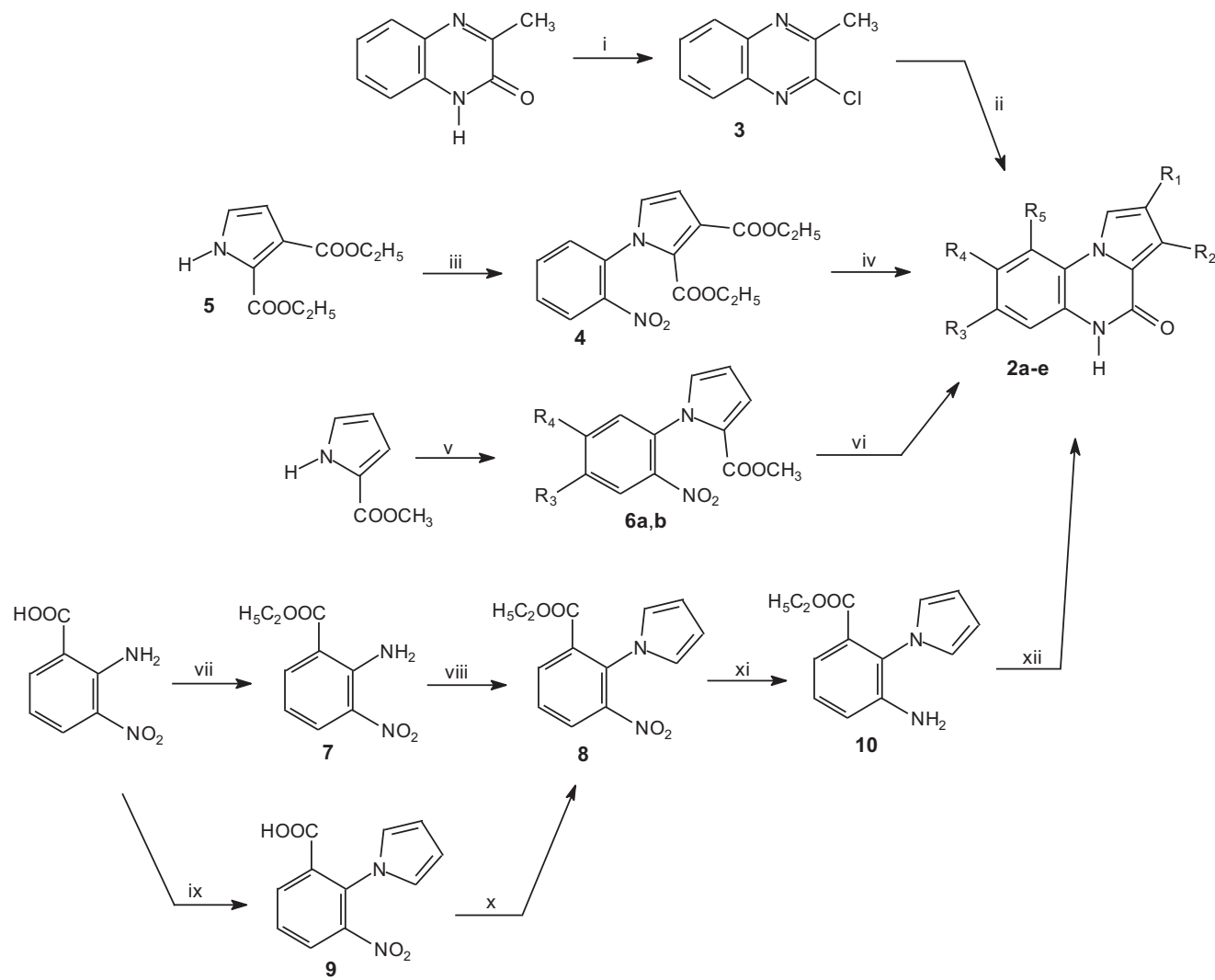

\begin{tabular}{cccccc}
\hline compound & $\mathrm{R}_{1^{-}}$ & $\mathrm{R}_{\mathbf{2}^{-}}$ & $\mathrm{R}_{3^{-}}$ & $\mathrm{R}_{4^{-}}$ & $\mathrm{R}_{5^{-}}$ \\
\hline $\mathbf{2 a}$ & $-\mathrm{COOC}_{2} \mathrm{H}_{5}$ & $\mathrm{H}-$ & $\mathrm{H}-$ & $\mathrm{H}-$ & $\mathrm{H}-$ \\
$\mathbf{2 b}$ & $\mathrm{H}-$ & $-\mathrm{COOC}_{2} \mathrm{H}_{5}$ & $\mathrm{H}-$ & $\mathrm{H}-$ & $\mathrm{H}-$ \\
$\mathbf{6 a}, \mathbf{2 c}$ & $\mathrm{H}-$ & $\mathrm{H}-$ & $-\mathrm{COOC}_{2} \mathrm{H}_{5}$ & $\mathrm{H}-$ & $\mathrm{H}-$ \\
$\mathbf{6 b}, \mathbf{2 d}$ & $\mathrm{H}-$ & $\mathrm{H}-$ & $\mathrm{H}-$ & $-\mathrm{COOC}_{2} \mathrm{H}_{5}$ & $\mathrm{H}-$ \\
$\mathbf{2} \mathbf{e}$ & $\mathrm{H}-$ & $\mathrm{H}-$ & $\mathrm{H}-$ & $\mathrm{H}-$ & $-\mathrm{COOC}_{2} \mathrm{H}_{5}$ \\
\hline
\end{tabular}

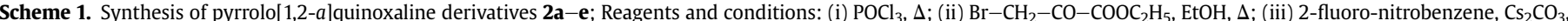

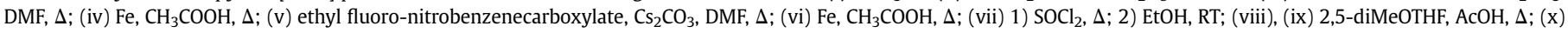
$\mathrm{SOCl}_{2}$, EtOH, $\Delta$; (xi) $\mathrm{CuSO}_{4} / \mathrm{NaBH}_{4}$, EtOH, RT; (xii) $\left(\mathrm{Cl}_{3} \mathrm{CO}\right)_{2} \mathrm{CO}$, toluene, $\Delta$. 
<smiles>[R]c1cc2[nH]c(=O)c3c([R])c([R])cn3c2c([R])c1[R]</smiles><smiles>[R]c1cc2nc(Cl)c3c([R])c([R3])cn3c2c([R3])c1[R]</smiles><smiles>[R]c1cccc(Nc2nc3cc([R])c([R])c([R])c3n3cc([R])c([R])c23)c1</smiles><smiles>[R]c1cccc(Nc2nc3cc([R])c([R])c([R])c3n3cc([R])c([R])c23)c1</smiles>

\begin{tabular}{|c|c|c|c|c|c|c|}
\hline compound & $\mathrm{R}_{1}-$ & $\mathrm{R}_{2^{-}}$ & $\mathrm{R}_{3^{-}}$ & $\mathrm{R}_{4^{-}}$ & $\mathrm{R}_{5^{-}}$ & R- \\
\hline $2 a, 11 a, 12 a, b$ & $-\mathrm{COOC}_{2} \mathrm{H}_{5}$ & $\mathrm{H}-$ & $\mathrm{H}-$ & $\mathrm{H}-$ & $\mathrm{H}-$ & $-\mathrm{Cl},-\mathrm{C} \equiv \mathrm{CH}$ \\
\hline / $\mathbf{1 a}, \mathbf{b}$ & / - $\mathrm{COOH}$ & & & & & \\
\hline $2 b, 11 b, 12 c, d$ & $\mathrm{H}-$ & $-\mathrm{COOC}_{2} \mathrm{H}_{5}$ & $\mathrm{H}-$ & $\mathrm{H}-$ & $\mathrm{H}-$ & $-\mathrm{Cl},-\mathrm{C} \equiv \mathrm{CH}$ \\
\hline$/ 1 c, d$ & & / $-\mathrm{COOH}$ & & & & \\
\hline $2 c, 11 c, 12 e, f$ & $\mathrm{H}-$ & $\mathrm{H}-$ & $-\mathrm{COOC}_{2} \mathrm{H}_{5}$ & $\mathrm{H}-$ & $\mathrm{H}-$ & $-\mathrm{Cl},-\mathrm{C} \equiv \mathrm{CH}$ \\
\hline$/ 1 \mathrm{e}, \mathrm{f}$ & & & / - $\mathrm{COOH}$ & & & \\
\hline 2d, 11d, 12g,h & $\mathrm{H}-$ & $\mathrm{H}-$ & $\mathrm{H}-$ & $-\mathrm{COOC}_{2} \mathrm{H}_{5}$ & $\mathrm{H}-$ & $-\mathrm{Cl},-\mathrm{C} \equiv \mathrm{CH}$ \\
\hline / 19,h & & & & / - $\mathrm{COOH}$ & & \\
\hline $2 e, 11 e, 12 i, j$ & $\mathrm{H}-$ & $\mathrm{H}-$ & $\mathrm{H}-$ & $\mathrm{H}-$ & $-\mathrm{COOC}_{2} \mathrm{H}_{5}$ & $-\mathrm{Cl},-\mathrm{C} \equiv \mathrm{CH}$ \\
\hline$/ 1 \mathrm{i}, \mathrm{j}$ & & & & & / - $\mathrm{COOH}$ & \\
\hline
\end{tabular}

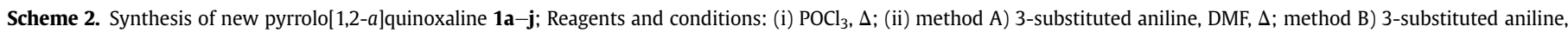
$\mathrm{Pd}(\mathrm{OAc})_{2}, \mathrm{Cs}_{2} \mathrm{CO}_{3}$, BINAP, toluene, $\Delta$; (iii) 1$\left.) \mathrm{NaOH}, \mathrm{MeOH} / \mathrm{H}_{2} \mathrm{O}, \Delta ; 2\right) \mathrm{HCl}$ aq. (1 M), $\mathrm{H}_{2} \mathrm{O}$.

Lee [30]. This $\mathrm{NaBH}_{4}-\mathrm{CuSO}_{4}$ system was found to be quite powerful in reducing our aromatic nitro groups with excellent yield (90\%). The reaction of $\mathbf{1 0}$ with triphosgene in toluene gave the lactame 2e [16].

These lactames $\mathbf{2 a}-\mathbf{e}$ were subsequently chlorodehydroxylated with phosphorous oxychloride, leading to the 4-chloropyrrolo[1,2a]quinoxalines 11a-e (Scheme 2). These 4-chloropyrrolo[1,2-a] quinoxaline derivatives 11a-e underwent nucleophilic attack by the 3-chloro or 3-ethynylanilines in refluxing dimethylformamide to give the 4-anilinopyrrolo[1,2-a]quinoxalines $\mathbf{1 2 a}-\mathbf{j}$ [31]. The 4anilinopyrrolo[1,2-a]quinoxalines $\mathbf{1 2 a} / \mathbf{c} / \mathbf{e} / \mathbf{g} / \mathbf{i}$ were also prepared in quite good yields (68-85\%) by a direct Buchwald-Hartwig crosscoupling reaction of 4-chloropyrroloquinoxalines 11a-e with 3chloroaniline using catalytic amounts of $\mathrm{Pd}(\mathrm{OAc})_{2}$ and BINAP, and $\mathrm{Cs}_{2} \mathrm{CO}_{3}$ as a base [32]. The desired acids $\mathbf{1 a}-\mathbf{j}$ were obtained by alkaline hydrolysis of the parent esters $\mathbf{1 2 a}-\mathbf{j}$ in good yields. The 3D spatial determination of $\mathbf{1 f}$ was established by X-ray crystallography [33], and confirmed the structure in the solid state as anticipated on the basis of IR and ${ }^{1} \mathrm{H}$ NMR data (Fig. 3).

The 7-anilinopyrroloquinoxaline-4-carboxylic acids $\mathbf{1 k}, \mathbf{1}$ were synthesized in six or seven steps from commercially available 4bromo-2-nitroaniline (Scheme 3). Preparation of 1-(4-bromo-2-nit rophenyl)pyrrole 13 was performed according to the Clauson-Kaas reaction runned under micro-waves irradiation starting from 4bromo-2-nitroaniline and 2,5-dimethoxytetrahedrofuran in acetic acid. The resulting phenylpyrrole $\mathbf{1 3}$ intermediate was subsequently reduced using a $\mathrm{NaBH}_{4}-\mathrm{CuSO}_{4}$ treatment into the attempted 1-(2-amino-4-bromophenyl)pyrrole 14 [18]. Addition of 14 to ethyl chlorooxoacetate in the presence of triethylamine provided the ester 15 [34,35]. The ethyl 7-bromopyrrolo[1,2-a] quinoxaline-4-carboxylate $\mathbf{1 6}$ was then prepared by cyclization of the amido-ester 15 in refluxing phosphorus oxychloride [36]. The 3D spatial structure of ethyl 7-bromopyrrolo[1,2-a]quinoxaline-4carboxylate $\mathbf{1 6}$ was established by X-ray crystallography [33] and confirmed the structure (Fig. 4).

Then the ethyl 7-anilinopyrrolo[1,2-a]quinoxaline-4carboxylates 12k,1 were synthesized via the Buchwald palladiumcatalyzed cross-coupling reaction of 3-chloroaniline or 3-(trimethylsilylethynyl)aniline [37,38] with $\mathbf{1 6}$ in the presence of BINAP and cesium carbonate (Scheme 3). The deprotection of the acetylene moiety of compound $\mathbf{1 2 1}$ by tetrabutylammonium fluoride (TBAF) led to anilinopyrrolo[1,2-a]quinoxaline 17 [39,40]. The palladium-catalyzed cross-coupling reaction of unprotected 3ethynylaniline with $\mathbf{1 6}$ directly gave the Sonogashira side product 18 (Scheme 4). The hydrolysis of the ester function of derivatives $\mathbf{1 2 k}, \mathbf{1 7}$ and 18 in basic conditions gave the pyrroloquinoxalines $\mathbf{1 k}, \mathbf{l}$ and $\mathbf{1 9}$, respectively.

The synthesis of the 4-anilinopyrrolo[1,2-a]quinoxaline-7carboxylic acids $\mathbf{1 m}, \mathbf{n}$, substituted in position 2 by a pyridine moiety, was depicted in Scheme 5. The methyl 4-bromopyrrole carboxylate $\mathbf{2 0}$ was prepared by regioselective bromination of methyl pyrrole-2-carboxylate [24]. This bromopyrrole ester $\mathbf{2 0}$ was then protected as the corresponding tert-butyl carbamate to afford $\mathbf{2 1}$ in nearly quantitative yield. The role of the Boc group is not to protect nitrogen but to reduce the electron density of the pyrrole to avoid extensive dehalogenation. Coupling Boc-protected 21 with 3-pyridylboronic acid under Suzuki-Miyaura cross-coupling 


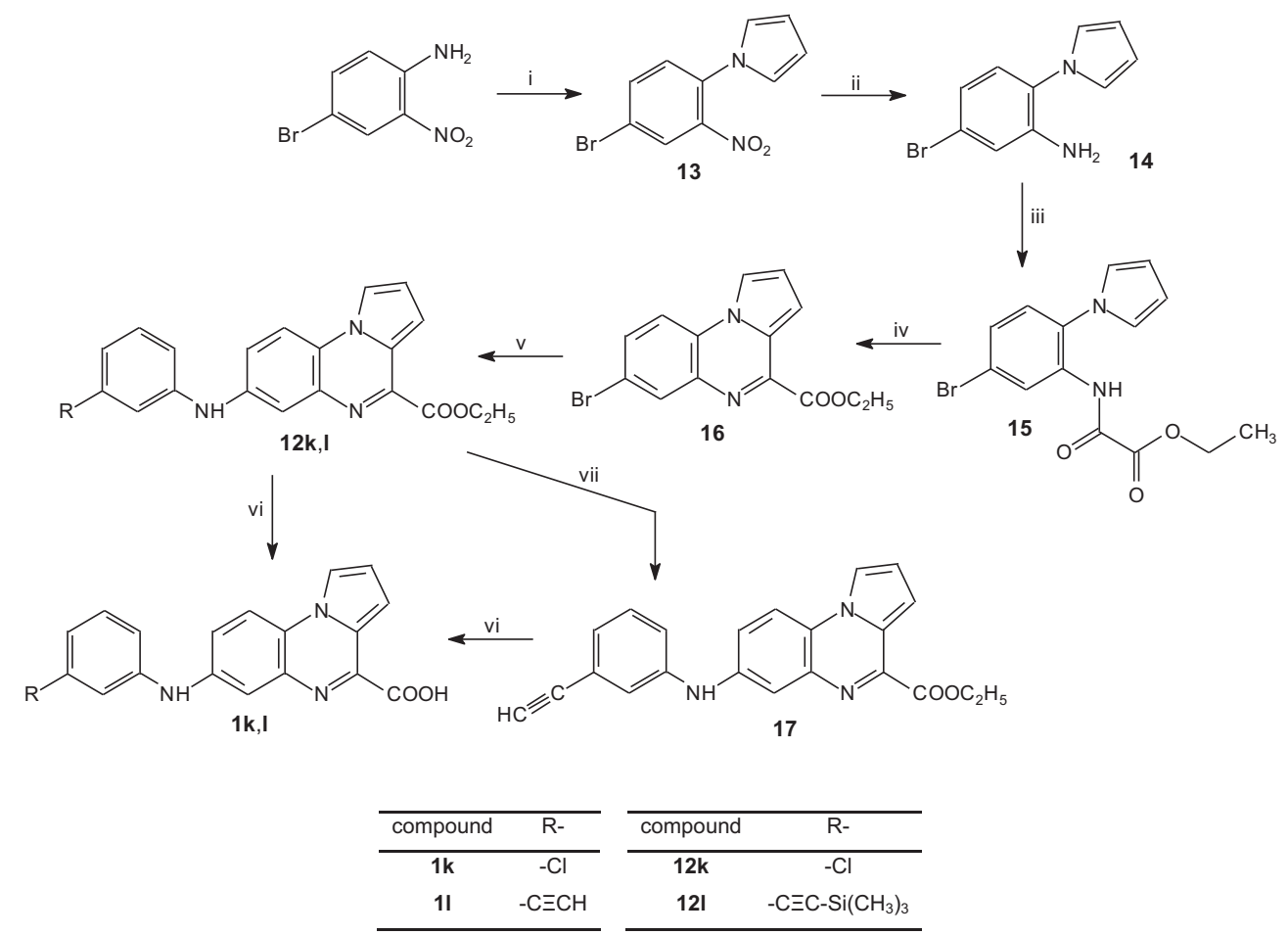

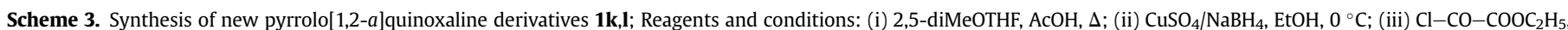

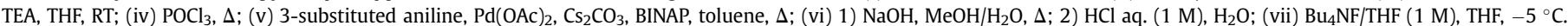

conditions proceeded cleanly to afford the 4-phenyl-1H-pyrrole-2carboxylic acid methyl ester $\mathbf{2 2}$ after deprotection of the $\mathbf{N H}$ using a trifluoroacetic acid solution. An X-ray single crystal analysis was also performed on pyrrole $\mathbf{2 2}$ in order to confirm the structure (Fig. 5) [33]. The preparation of $\mathrm{N}$-aryl pyrrole $\mathbf{2 3}$ were obtained by nucleophilic substitution of the methyl 4-(3-pyridyl)pyrrole-2carboxylate 22 with ethyl 4-fluoro-3-nitrobenzenecarboxylate using cesium carbonate in refluxing DMF solution (Scheme 5). Reduction of the nitro moiety with iron in hot acetic acid afforded the desired lactame $\mathbf{2 f}$. The lactame $\mathbf{2 f}$ was subsequently chlorodehydroxylated with phosphorous oxychloride, leading to the 4chloroquinoxalines 11f. Nucleophilic displacement of the chlorine by various substituted anilines in $\mathbf{1 1 f}$ and ester hydrolysis provided carboxylates 12m,n and acids $\mathbf{1 m}, \mathbf{n}$.

\section{Biological activity}

\subsection{Inhibition of human CK2 holoenzyme}

These new synthesized pyrrolo[1,2-a]quinoxaline-carboxylic acid derivatives were tested for their inhibitory activity toward human CK2 holoenzyme (Table 1). The synthetic peptide RRRDDDSDDD was used as the substrate, which is reported to be most efficiently phosphorylated by CK2. The purity of the CK2 holoenzyme was superior to 99\% (Fig. 6) [41]. For initial testing, inhibition was determined relative to the controls at inhibitor concentrations of $10 \mu \mathrm{M}$ in DMSO as the solvent. Final concentration of DMSO never exceeded $1 \%$ of the entire reaction volume. The reaction with pure solvent without inhibitor was used as negative

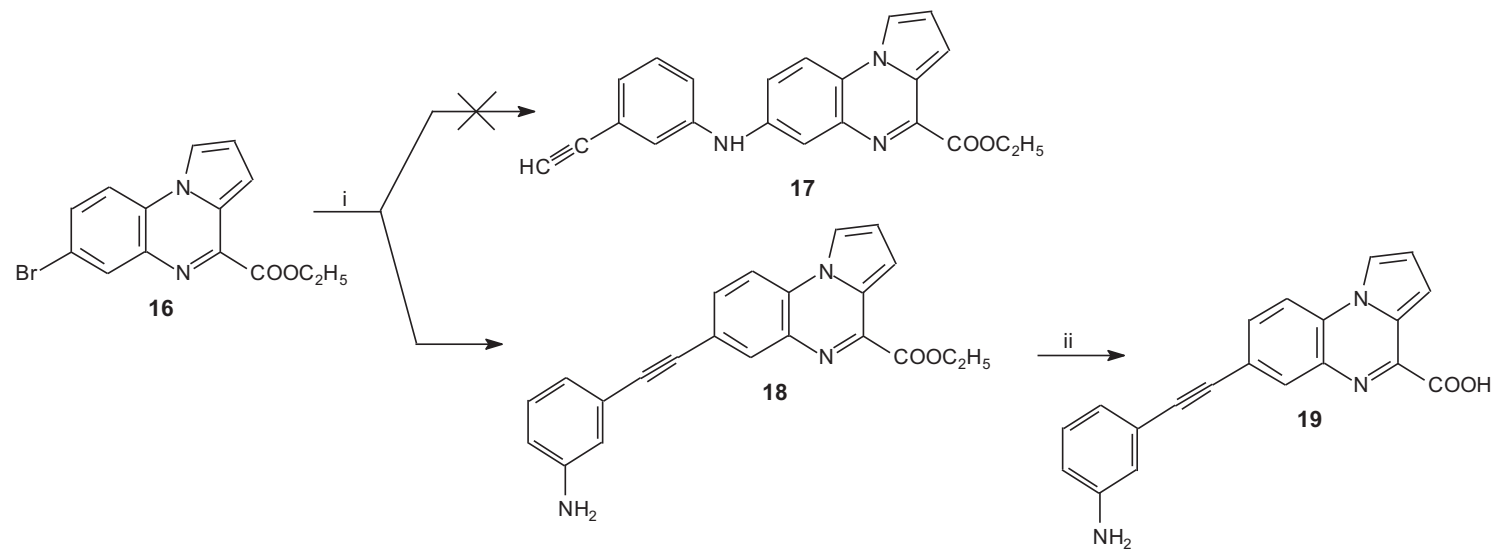

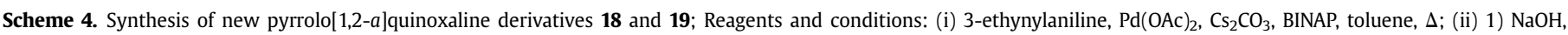
$\left.\mathrm{MeOH} / \mathrm{H}_{2} \mathrm{O}, \Delta ; 2\right) \mathrm{HCl}$ aq. (1 M), $\mathrm{H}_{2} \mathrm{O}$. 


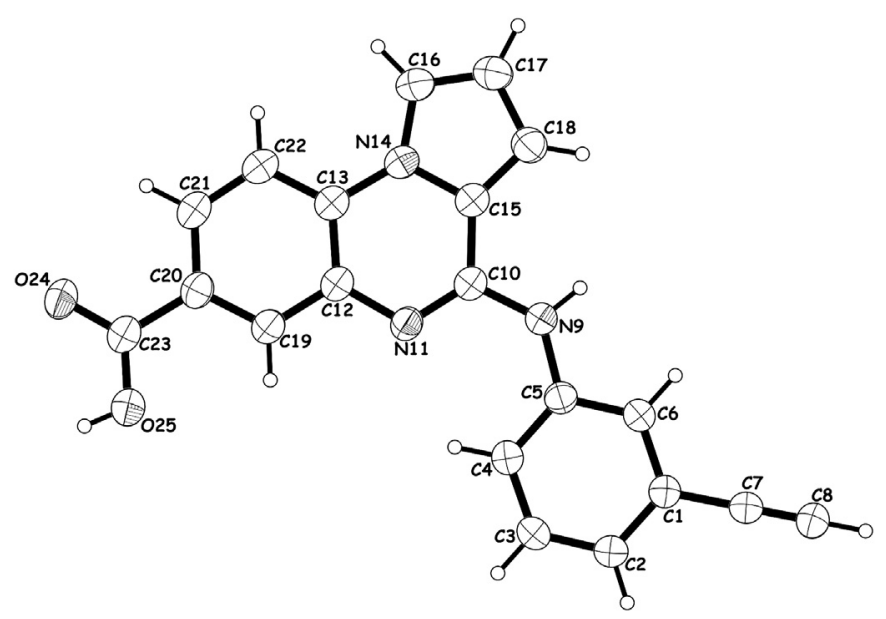

Fig. 3. The ORTEP drawing of pyrrolo[1,2-a]quinoxaline 1f with thermal ellipsoids at $30 \%$ level.

control and set to $0 \%$ inhibition. Reactions without CK2 were used as positive control and set to $100 \%$ inhibition. Compounds with more than $50 \%$ inhibition at a concentration of $10 \mu \mathrm{M}$ were subjected to an $\mathrm{IC}_{50}$ determination. For this purpose, inhibition was measured at final concentrations ranging from 0.01 to $30 \mu \mathrm{M}$ in appropriate intervals. $\mathrm{IC}_{50}$ were calculated from the resulting dose-response curves. Each value was determined at least in triplicate in independent experiments [42].

From the 15 synthesized pyrrolo[1,2-a]quinoxalines, we found thirteen potent compounds with an inhibition of more than $50 \%$ at a concentration of $10 \mu \mathrm{M}(\mathbf{1} \mathbf{a}-\mathbf{h}, \mathbf{1 k}-\mathbf{n}$ and 19). Nine of them $(\mathbf{1 c}-\mathbf{h}$, $\mathbf{1 k}, \mathbf{1}$ and $\mathbf{1 n}$ ) revealed $\mathrm{IC}_{50}$ in the sub-micromolar range (from 0.049 to $0.982 \mu \mathrm{M})$.

Among compounds $\mathbf{1 e}-\mathbf{j}$, which were bearing the 3-substituted aniline in position 4 of the heterocycle and the carboxylic acid function into the benzene of the quinoxaline moiety, the pyrrolo [1,2- $a]$ quinoxalines $\mathbf{1 e}$ and $\mathbf{1 f}$ exhibited the best inhibitory activity toward CK2 ( $\mathrm{IC}_{50}=0.118$ and $0.078 \mu \mathrm{M}$, respectively). Comparison of derivatives $\mathbf{1 g}, \mathbf{h}$ and $\mathbf{1 i}, \mathbf{j}$ with $\mathbf{1 e}, \mathbf{f}$ indicated that the presence of a carboxylic acid function at C8 position or C9 position yielded significantly less potent inhibitors of CK2, showing that the carboxylic acid group at C7 position was optimal in analogy with the reference drug CX-4945. Moreover, replacement of the 3chloroaniline by a 3-ethynylaniline did not lead to significant modification in the inhibition of CK2 IC $_{50}=0.120 \mu \mathrm{M}$ for $\mathbf{1 e}$ versus $0.080 \mu \mathrm{M}$ for $\mathbf{1 f}$, and $\mathrm{IC}_{50}=0.834 \mu \mathrm{M}$ for both $\mathbf{1 g}$ and $\mathbf{1 h}$ ).

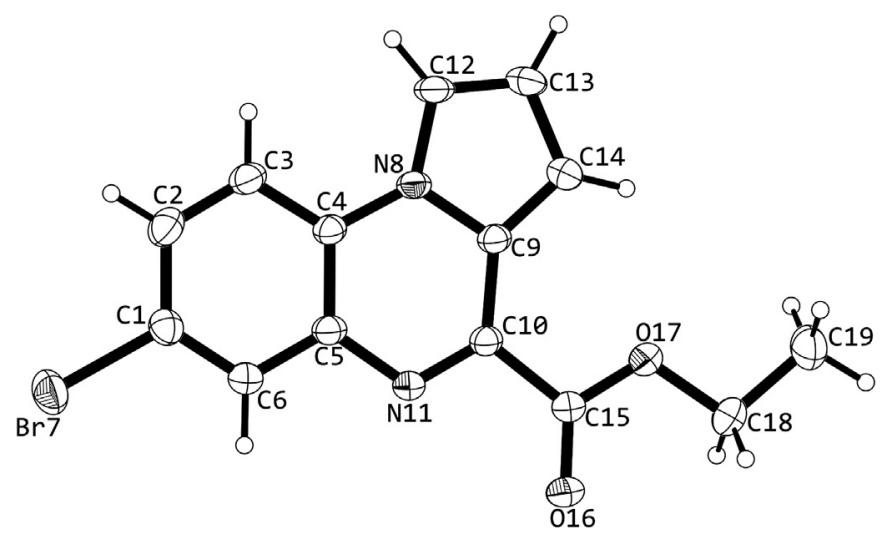

Fig. 4. The ORTEP drawing of pyrrolo[1,2-a]quinoxaline $\mathbf{1 6}$ with thermal ellipsoids at $30 \%$ level.
Moreover, in terms of structure-activity relationships discussion, it could be also noticed that the $\mathrm{IC}_{50}$ values of compound $\mathbf{1 a}$ and $\mathbf{1 b}$ bearing the carboxylic acid group on the pyrrole moiety, i.e. at position 2 of the heterocyclic skeleton and the 3-substituted aniline in position $4\left(\mathrm{IC}_{50}=4.28\right.$ and $\left.1.89 \mu \mathrm{M}\right)$, were found 35 and 24 times lower than those of their 7-substituted analogs 1e,f. Surprisingly, molecules 1c and 1d, in which the carboxylic acid was moved to the pyrrolic adjacent carbon, were found to be much more active in their CK2 inhibitory activity, showing that its position on $\mathrm{C} 3$ was necessary for potent inhibition. The most promising compound, the 4-[(3-chlorophenyl)amino]pyrrolo[1,2-a]quinoxaline-3-carboxylic acid 1c inhibited human $\mathrm{CK} 2$ with an $\mathrm{IC}_{50}$ of $49 \mathrm{nM}$. Substitution of the 3-chloroaniline by a 3-ethynylaniline in compound 1d led to a small decrease in the inhibitory activity $\left(\mathrm{IC}_{50}=134 \mathrm{nM}\right)$.

The transposition of the 3-substituted aniline and the carboxylic acid from their respective position 4 and 7 in compounds 1e,f to position 7 and 4 (compounds $\mathbf{1 k}, \mathbf{l}$ ) induced a strong decrease in the inhibitory activity of $\mathrm{CK} 2$ ( $\mathrm{IC}_{50} 0.982 \mu \mathrm{M}$ for $\mathbf{1 k}$ compared with $0.118 \mu \mathrm{M}$ for $1 \mathrm{e}$; and $\mathrm{IC}_{50} 0.850 \mu \mathrm{M}$ for $\mathbf{1 1}$ compared with $0.078 \mu \mathrm{M}$ for 1f).

In analogy with the reference compound CX-4945, we next introduced a pyridine into the tricyclic pyrrolo[1,2-a]quinoxaline core with the objective to add a hydrogen bond acceptor. In the hinge region, it was noticed a hydrogen bonding interaction between the pyrido moiety of CX-4945 and the NH of Val116. However, incorporation of a 3-pyridyl moiety in position 2 of the pyrroloquinoxaline scaffold (compounds 1e,f) leading to compounds $\mathbf{1 m}, \mathbf{n}$ induced a 10 -fold lower CK2 inhibitory activity, with $\mathrm{IC}_{50}$ from 0.89 (compound $\mathbf{1 n}$ ) to $1.57 \mu \mathrm{M}$ (compound $\mathbf{1 m}$ ).

From a SAR point of view, these preliminary biological results on the inhibitory activity toward human CK2 holoenzyme revealed the importance of the substitution at the C-4 position of the pyrroloquinoxaline scaffold by a 3-substituted aniline, and also revealed the need of a carboxylic acid functionality on position 3 of the pyrrole ring. However, in a general way, it could also be noticed that the nature of the substitution at position 3 in the aniline moiety was less detrimental than the position of the carboxylic acid function for the CK2 inhibitory activity of the pyrroloquinoxaline derivatives $\mathbf{1}$.

\subsection{Antiproliferative effect}

The antiproliferative profile of the most promising CK2 inhibitors $\mathbf{1}$ (compounds $\mathbf{1 a}-\mathbf{h}$ and $\mathbf{1 k}$ ) at increasing concentrations $(0,1,5,10,20$ and $50 \mu \mathrm{M})$ was then evaluated in MTS assay for their in vitro antiproliferative activity against four human leukemic cell lines (U937, K562, Jurkat and MV-4-11). Compound CX-4945, which showed strong CK2 inhibition, was applied as a referential cytotoxic agent with potent antiproliferative activity against our cell lines. The results of the antiproliferative activity studies are summarized in Table 2.

On K562 cell line, all the tested pyrroloquinoxalines $\mathbf{1}$ were found to be inactive $\left(\mathrm{CC}_{50}>50 \mu \mathrm{M}\right)$, with the exception of 1c that presented very moderate antiproliferative activity with a $\mathrm{CC}_{50}$ of $42 \mu \mathrm{M}$, while $\mathrm{CX}-4945$ presented a $\mathrm{CC}_{50}$ of $7 \mu \mathrm{M}$.

Among compounds $\mathbf{1 a}-\mathbf{h}$ and $\mathbf{1 k}$, the derivatives $\mathbf{1 c}$ and $\mathbf{1 k}$ exhibited a low antiproliferative activity on the growth of U937 monocytic cell line ( $\mathrm{CC}_{50}$ values of 47.7 and $39.2 \mu \mathrm{M}$, respectively). On this U937 cell line, reference CX-4945 showed a $\mathrm{CC}_{50}$ of $4.2 \mu \mathrm{M}$.

Against the Jurkat T-lymphoblastic cell line, we also observed moderate antiproliferative activities for compounds $\mathbf{1 b}$ and $\mathbf{1 k}$ which presented $\mathrm{CC}_{50}$ of 41 and $31.4 \mu \mathrm{M}$, respectively. These antiproliferative activities were found 10 -fold lower than the one of $\mathrm{CX}$ $4945\left(\mathrm{CC}_{50}=4.5 \mu \mathrm{M}\right)$. 

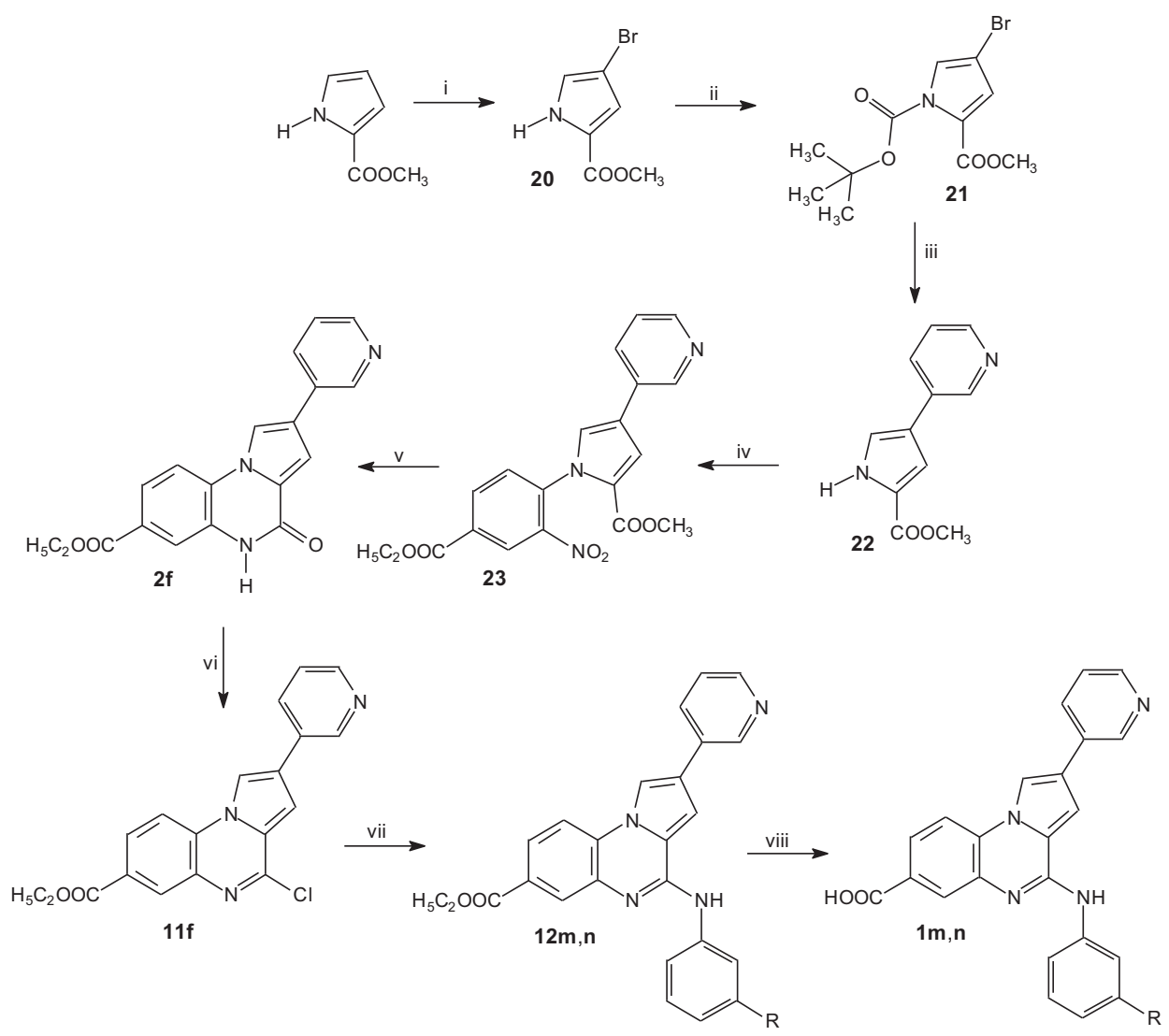

\begin{tabular}{cc}
\hline compound & R- \\
\hline $12 \mathrm{~m}, 1 \mathrm{~m}$ & $-\mathrm{Cl}$ \\
$12 \mathrm{n}, 1 \mathrm{n}$ & $-\mathrm{C} \equiv \mathrm{CH}$ \\
\hline
\end{tabular}

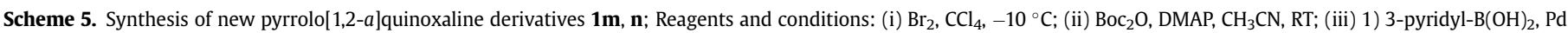

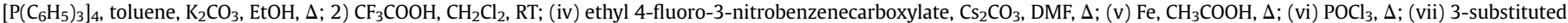
aniline, DMF, $\Delta$; (viii) 1) $\mathrm{NaOH}, \mathrm{MeOH} / \mathrm{H}_{2} \mathrm{O}, \Delta$; 2) $\mathrm{HCl}$ aq. (1 M), $\mathrm{H}_{2} \mathrm{O}$.

In the most sensitive acute myeloblastic leukemia cells MV-4-11, compounds 1e,f were active at a $20 \mu \mathrm{M}$ concentration, whereas their structural analog $\mathbf{1 k}$ in which the aniline moiety and the carboxylic acid function were inverted between the 4 and 7 positions of the pyrroloquinoxaline skeleton was found twice less active $\left(\mathrm{CC}_{50}=47 \mu \mathrm{M}\right)$. For compound $\mathrm{CX}-4945$, a $\mathrm{CC}_{50}$ of $3 \mu \mathrm{M}$ was observed on MV-4-11, 7-fold lower than the $\mathrm{CC}_{50} \mathrm{~S}$ of pyrroloquinoxalines 1e,f.

\subsection{Cytotoxicity}

The CK2 inhibitor compounds $\mathbf{1 a}-\mathbf{h}$ and 1k were tested on activated (PBMNC + PHA) human peripheral blood mononuclear cells to evaluate their respective cytotoxicity on normal cells (Table 2). As expected, all the tested pyrrolo[1,2-a]quinoxalines 1 presented a $\mathrm{CC}_{50}$ superior to $50 \mu \mathrm{M}$ against lymphocytes. Compound $\mathrm{CX}-4945$ exhibited a $\mathrm{CC}_{50}$ of $50 \mu \mathrm{M}$. These preliminary results were used to determine their respective range of toxic concentration.

Indexes of selectivity (IS) were defined as the ratio of the $\mathrm{CC}_{50}$ value on the human mononuclear cells to the $\mathrm{CC}_{50}$ value on the K562, U937, Jurkat and MV-4-11 lines. Compounds that demonstrated high selectivity (high index of selectivity) should offer a potential of safer therapy. This led to identify compounds with moderate index of selectivity $>2.5$ for compounds $\mathbf{1 e}, \mathbf{f}$ on the human leukemic cell line MV-4-11, and 1.6 for compound 1k against the Jurkat T-lymphoblastic cell line. The reference compound CX4945 showed high selectivity with index of selectivity values noticed between 7.1 and 16.7.

\subsection{Lipophilicity and cell permeability}

As a previous study on design of indeno[1,2-b]indole derivatives as CK2 inhibitors [43], predictive ADME parameters were used to determine their biological profile. Then for an evaluation of the cell permeability of pyrroloquinoxalines $\mathbf{1 a}-\mathbf{h}$ and $\mathbf{k}-\mathbf{n}$, fragmentbased partition coefficients (Clog $P$ ) and topological polar surface areas (TPSA) were calculated by the molinspiration web services [44]. Compounds $\mathbf{1 a}-\mathbf{h}$ and $\mathbf{k}-\mathbf{n}$ presented $C \log P$ values between 3.986 for $\mathbf{1 b}$ and 5.94 for $\mathbf{1 m}$. TPSA values were noticed between 66.633 and $79.525 \AA^{2}$.

A plot of CK2 inhibitory activity $\left(\mathrm{IC}_{50}\right)$ versus $C \log P$ values was presented in Fig. 7, allowing us to classify compounds $\mathbf{1 a}-\mathbf{n}$ in various subsets. The less lipophilic compounds (1b, 1d, $\mathbf{1 l}$ and $\mathbf{1 h})$ with $C \log P$ values from 3.986 to 4.373 exhibited moderate CK2 inhibitory activities ( IC $_{50}=0.834-1.89 \mu \mathrm{M}$ ) excepted 1d showing an $\mathrm{IC}_{50}$ of $0.134 \mu \mathrm{M}$. The most active pyrroloquinoxalines $\mathbf{1 f}$ and 1c with $\mathrm{IC}_{50}$ of 0.078 and $0.049 \mu \mathrm{M}$ presented $C \log P$ of 4.373 and 


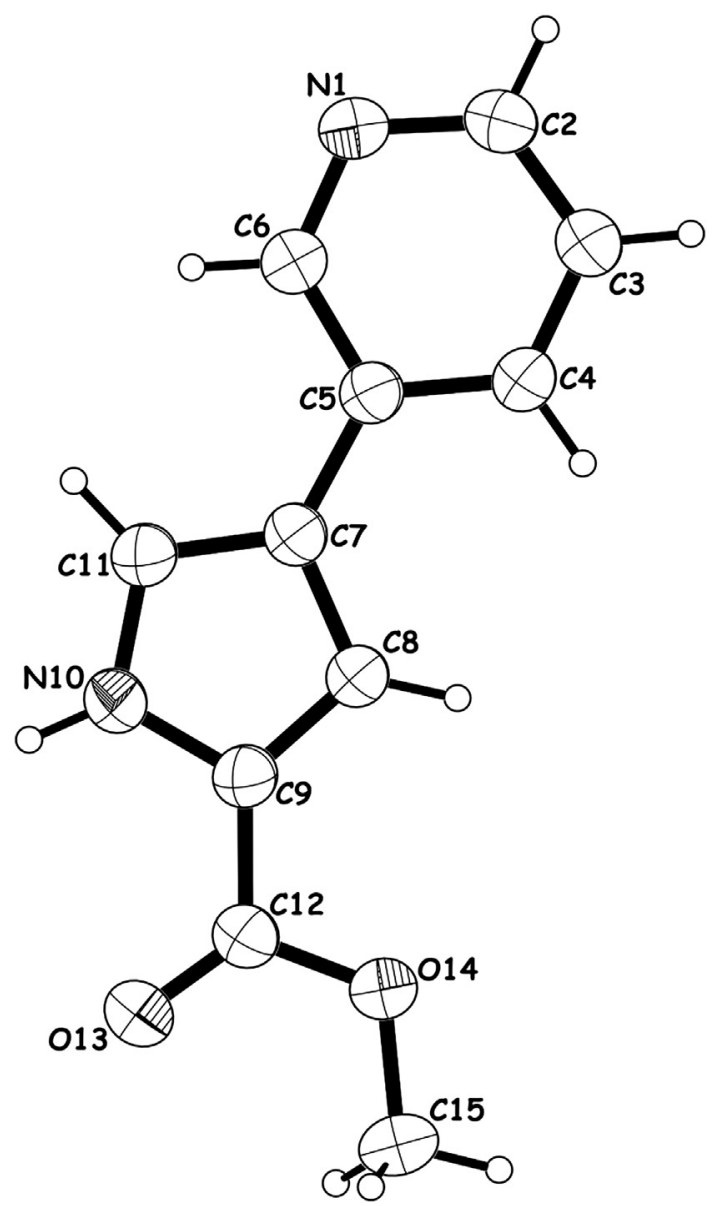

Fig. 5. The ORTEP drawing of ethyl 4-(3-pyridyl)-1H-pyrrole-2-carboxylate 22 with thermal ellipsoids at $30 \%$ level.

4.901, respectively. The three compounds (1a, 1n and 1k) with Clog $P$ values between 4.901 and 5.065 were found to be less active $\left(\mathrm{IC}_{50}=0.89-4.28 \mu \mathrm{M}\right)$. The reference compound CX-4945 $\left(\mathrm{IC}_{50}=0.0037 \mu \mathrm{M}\right)$ showed a $C \log P$ of 5.136. At $C \log P$ of 5.288,

Table 1

CK2 inhibitory activity of new substituted pyrrolo[1,2- $a$ ]quinoxaline-carboxylic acid derivatives.

\begin{tabular}{|c|c|c|}
\hline Compound & Inhibition (\%) & $\begin{array}{l}\text { CK2 } \\
\mathrm{IC}_{50}(\mu \mathrm{M})^{\mathrm{b}}\end{array}$ \\
\hline Ellagic acid & 95 & 0.040 \\
\hline Emodin & 99 & 0.580 \\
\hline TBB & 99 & 0.060 \\
\hline CX-4945 & 100 & 0.0037 \\
\hline $1 a$ & 68 & 4.28 \\
\hline 1b & 86 & 1.89 \\
\hline 1c & 99 & 0.049 \\
\hline 1d & 99 & 0.134 \\
\hline $1 e$ & 92 & 0.118 \\
\hline 1f & 95 & 0.078 \\
\hline $1 \mathrm{~g}$ & 93 & 0.834 \\
\hline $1 \mathrm{~h}$ & 81 & 0.834 \\
\hline $1 \mathbf{i}$ & 20 & n.d. \\
\hline $\mathbf{1 j}$ & 22 & n.d. \\
\hline 1k & 99 & 0.982 \\
\hline 11 & 95 & 0.850 \\
\hline $1 \mathrm{~m}$ & 75 & 1.57 \\
\hline $1 n$ & 89 & 0.89 \\
\hline 19 & 55 & 8.25 \\
\hline
\end{tabular}

a Given is the average percent inhibition at $10 \mu \mathrm{M}$.

b n.d.: not determined.

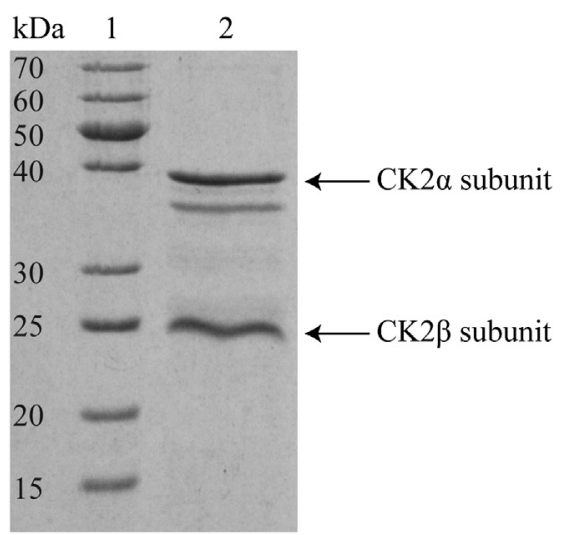

Fig. 6. SDS-PAGE of purified human protein kinase CK2 holoenzyme. $15 \mu \mathrm{L}$ of purified protein solution $(0.25 \mu \mathrm{g} / \mu \mathrm{L})$ were separated on a $12.5 \%$ acrylamide gel and stained with Coomassie Brilliant Blue G250. At the left, the apparent molecular mass of the marker proteins (lane 1) is given. Lane 2 shows the purified human CK2 enzyme holoenzyme $(3.75 \mu \mathrm{g})$. The band below the CK2 $\alpha$ belongs to the well-known degradation product of the $\alpha$-subunit CK2 $\alpha$ (amino acids $1-335$ ), which is supposed to be enzymatically active and usually occurs during purification [41].

derivatives $\mathbf{1 e}$ and $\mathbf{1 g}$ exhibited $\mathrm{IC}_{50}$ of 0.118 and $0.834 \mu \mathrm{M}$, respectively. Compound $\mathbf{1 m}$, showing the most lipophilic value $(C \log P=5.94)$, was less active $\left(\mathrm{IC}_{50}=1.57 \mu \mathrm{M}\right)$ on CK2.

Poor absorption and low permeability are predicted for drugs with $C \log P \geq 5$ and TPSA $\geq 140 \AA^{2}$ [45-47]. Thus, the two most active compounds 1c and 1f on CK2 showed acceptable lipophilic properties for cell permeability $(C \log P<5)$ but their cytotoxic activity on tested leukemia cell lines was limited (e.g. IC $50=20 \mu \mathrm{M}$ on MV-4-11 for 1f). Furthermore compound $1 \mathbf{k}\left(\mathrm{IC}_{50}=0.982 \mu \mathrm{M}\right.$ on CK2) and CX-4945 had similar Clog $P$ values (5.065 and 5.136, respectively) and compound $\mathbf{1 k}$ only presented slight cytotoxicity on three cell lines ( $31.4<\mathrm{IC}_{50} \mu \mathrm{M}<47$ ). This suggests that the Clog $P$ estimates did not seem to fit with our biological results. Further investigations are ongoing to optimize the correlation of physicochemical properties of pyrroloquinoxalines and their biological potencies.

\section{Molecular dynamics of CK2 complexes}

In order to investigate the molecular basis of the interaction of the CK2 ATP binding pocket with the $\mathbf{1 f}$ and 1c inhibitors, Molecular Dynamics (MD) simulation of CK2/1f and CK2/1c complexes

Table 2

In vitro activity of selected CK2 inhibitors compounds $\mathbf{1}$ on U937, K562, Jurkat and MV-4-11 cells, and cytotoxicity on human peripheral blood mononuclear cells PBMNC + PHA.

\begin{tabular}{llllll}
\hline $\mathrm{CC}_{50}$ values $(\mu \mathrm{M})^{\mathrm{a}}$ & & & & \\
\hline Compound & $\mathrm{K} 562$ & U937 & Jurkat & MV-4-11 & $\begin{array}{l}\text { Cytotoxicity on activated } \\
\text { human peripheral blood } \\
\text { mononuclear cells (PBMNC) } \\
\text { PBMNC + PHA }\end{array}$ \\
& & & & & 50 \\
\hline CX-4945 & 7 & 4.2 & 4.5 & 3 & $>50$ \\
$\mathbf{1 a}$ & $>50$ & $>50$ & $>50$ & $>50$ & $>50$ \\
$\mathbf{1 b}$ & $>50$ & $>50$ & 41 & $>50$ & $>50$ \\
$\mathbf{1 c}$ & 42 & 47.7 & $>50$ & $>50$ & $>50$ \\
$\mathbf{1 d}$ & $>50$ & $>50$ & $>50$ & $>50$ & $>50$ \\
$\mathbf{1 e}$ & $>50$ & $>50$ & $>50$ & 20 & $>50$ \\
$\mathbf{1 f}$ & $>50$ & $>50$ & $>50$ & 20 & $>50$ \\
$\mathbf{1 g}$ & $>50$ & $>50$ & $>50$ & $>50$ & $>50$ \\
$\mathbf{1 h}$ & $>50$ & $>50$ & $>50$ & $>50$ & $>50$ \\
$\mathbf{1 k}$ & $>50$ & 39.2 & 31.4 & 47 & \\
\hline
\end{tabular}

a The $\mathrm{CC}_{50}(\mu \mathrm{M})$ values correspond to the mean \pm standard deviation from 3 independent experiments. 


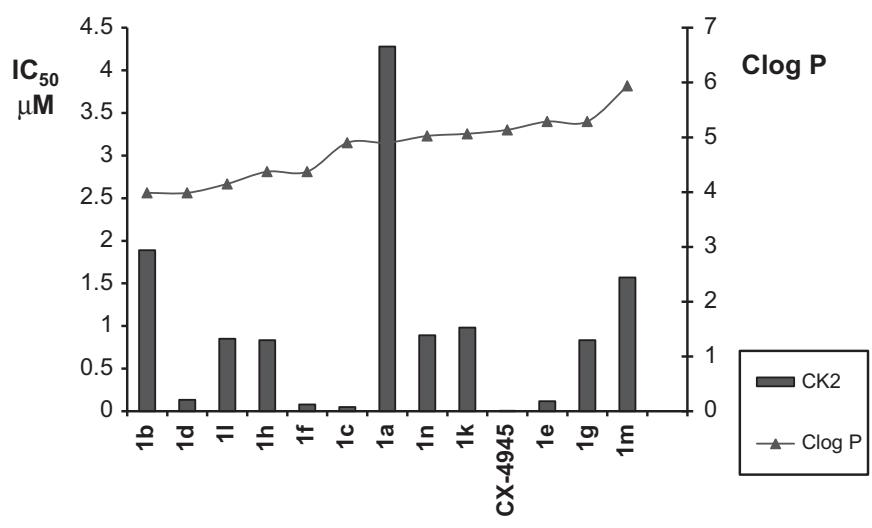

Fig. 7. Clog P-activity relationship for pyrrolo[1,2-a]quinoxalines $\mathbf{1 a}-\mathbf{n}$ upon CK2 inhibitory activity.

were performed. From the protein coordinates of the CK2/CX-4945 complex crystal structure (pdb: 3pe1) [48] (Fig. 8a; see Computational methods) and $\mathbf{1 f}$ and $\mathbf{1 c}$ optimized geometries, two protein/inhibitor systems were constructed and 40 ns MD runs were obtained employing an explicit box of TIP3P water molecules. Initially, a CK2/CX-4945 MD simulation was carried out as control trajectory, finding that both global complex conformation and polar protein-inhibitor interactions observed in the crystal structure resulted stable during the simulation time scale. Fig. $8 \mathrm{~b}$ shows that the nitrogen atom of the A-ring forms a hydrogen bond with the backbone nitrogen atom of Val116 (localized at the hinge $/ \alpha \mathrm{D}$ region), while on the opposite end of the CX-4945 molecule, the carboxyl group from the C-ring interacts in a strong polar network involving the Lys68, Glu81, Asp175 and two water molecules (positions $\mathrm{W} 1$ and $\mathrm{W} 2$ ). The $\mathrm{W} 1$ water molecule remained in its position throughout the 40 ns of the trajectory, while exchanges of water molecules at the W2 position were observed. We have also observed that the side chain (D-ring) of the ligand was more flexible than the rest of the molecule, although the global orientation was conserved. Finally, rotations of the His160 side chain occurred throughout the $40 \mathrm{~ns}$, continually switching from the up to the down conformations. Similar MD results related to the CX-4945 binding mode were recently reported by Liu et al. using another initial structure (pdb: 3nga) [49].

The MD simulation of the CK2/1f binding mode showed very similar results to those observed in the CX-4945 system (Fig. 8c). The main difference resides in the lack of polar interactions between the carbon atoms of the A-ring and the hinge $/ \alpha \mathrm{D}$ region, which increases the average distance between this protein region and the inhibitor (Table 3, distance A). Similar to the CX-4945 system, the carboxyl group of $\mathbf{1 f}$ is involved in an extensive polar interaction network, with a comparable average distance to the Lys68 (Table 3, distance B), but with a decrease in the average distance between the Lys68 and the Glu81 residues (Table 3, distance C). Moreover, the involvement of the W1 and W2 water molecules in the inhibitor binding mode and the dynamic behavior

\section{a}
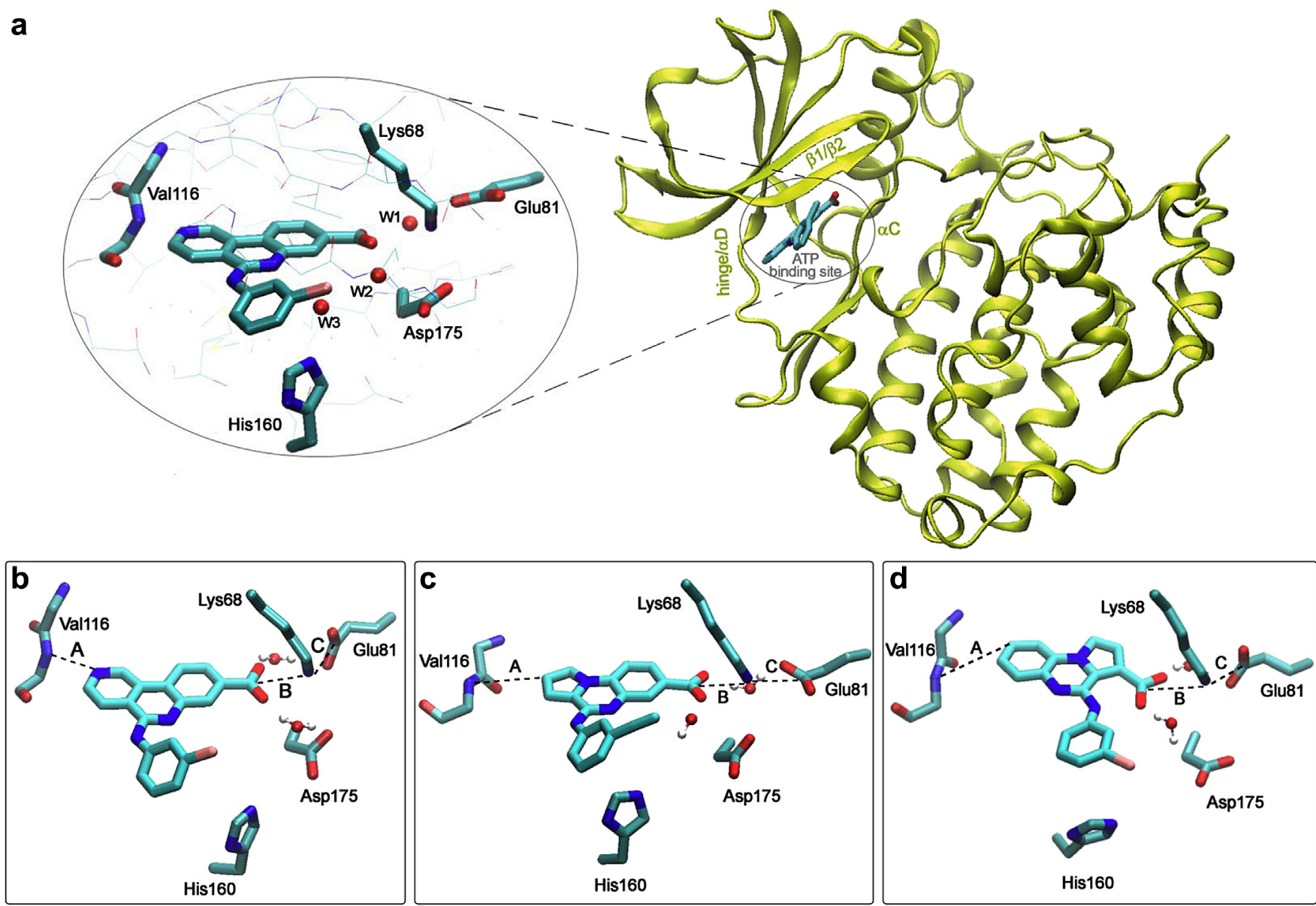

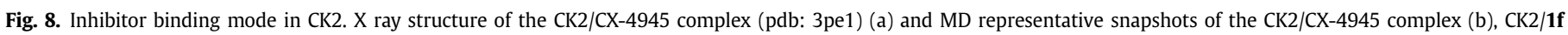
complex (c) and CK2/1c complex (d). 
Table 3

Average distance $(\AA)$.

\begin{tabular}{llll}
\hline & \multicolumn{2}{l}{ Average distance $(\AA)$} & 1c \\
\cline { 2 - 4 } & CX-4945 & 1f & $5.4 \pm 0.7$ \\
\hline A & $3.3 \pm 0.3$ & $4.7 \pm 0.4$ & $3.4 \pm 0.2$ \\
B & $3.3 \pm 0.1$ & $3.3 \pm 0.2$ & $3.4 \pm 0.2$ \\
C & $3.5 \pm 0.2$ & $3.8 \pm 0.5$ & \\
\hline
\end{tabular}

of both inhibitor side chain and His160 were similar to the trajectory control observed with CX-4945. All together these results suggest a very stable binding mode of the inhibitor $\mathbf{1 f}$, highlighting how five-member A-ring inhibitors could be able to interact within the ATP binding pocket of the CK2 protein.

We also studied the superposition of optimized geometries of $\mathbf{1 f}$ and 1c. Remarkably, when the superposition of both molecules was made through the central B-ring, but with an opposite orientation of the heterocyclic system (i.e. with the 1c A-ring sited at the position of the $\mathbf{1 f}$ C-ring, and vice versa), the position of both carboxyl groups resulted comparable, with a distance of $2.0 \AA$ between each other (Fig. 9). Even more the D-rings and their $m$-substituents acquired a similar orientation. Afterward, in order to carry out the CK2/1c MD simulation, the inhibitor was introduced within the ATP binding pocket in two different initial configurations: the first one with the heterocyclic system orientated as in the $\mathbf{1 f}$ system and the second one with the heterocyclic system in the opposite orientation. According to the MD results no polar interaction between 1c and receptor residues was observed when the inhibitor was introduced in the first configuration, resulting in less stable inhibitor trajectory (data not shown). In consequence, this configuration does not seem to be a suitable binding mode of $\mathbf{1 c}$. When the inhibitor was introduced in the opposite configuration, a tightly binding mode was established, with the carboxyl group contacting the Lys68 and forming part of the polar interaction network as in the CX-4945 and 1f systems (Fig. 8b,c). Indeed, the interaction between Lys68 and Glu81 residues resulted slightly larger than in the 1f system (Table 3 ). On the other hand, the average distance between the C-ring and the nitrogen backbone atom of Val116 resulted larger in the 1c system than in the 1f system. This is expected considering the larger steric impedance of a six-member ring (1c) in comparison with a five-member ring (1f) orientated to the hinge $/ \alpha \mathrm{D}$. Notably the intramolecular hydrogen bond formed between the carboxyl group and the nitrogen atom of B-ring remained stable during the 40 ns time scale of the simulation.

Finally, to compare qualitatively the different contributions to the binding energy of $\mathbf{1 f}$ and $\mathbf{1 c}$ to CK2, we calculated the electrostatic energy (ele) and Van der Waals contributions (vdw), the sum of which gave the total gas phase binding energy. The results revealed that vdw contribution is $2.7 \mathrm{kcal} / \mathrm{mol}$ more favorable in

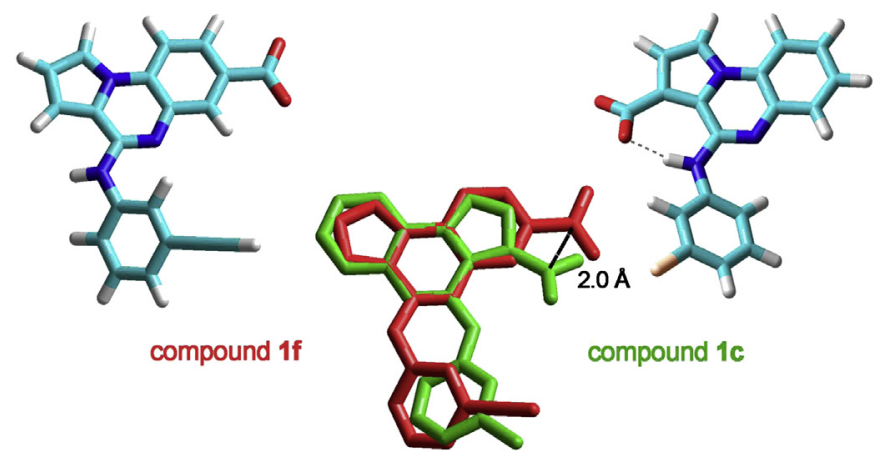

Fig. 9. HF/6-31G** optimized geometries of compounds $\mathbf{1 f}$ and $\mathbf{1 c}$ and their superposition generated by aligning the central B-ring. the $\mathbf{1 f}$ complex while the ele energy is $7.1 \mathrm{kcal} / \mathrm{mol}$ more favorable in the 1c complex. Thus, without considering the solvation and entropic effects, we found that the binding of 1c to CK2 was significantly stronger than that for $\mathbf{1 f}$. These observations qualitatively correlate with the respective experimental $\mathrm{IC}_{50}$ values.

\section{Conclusion}

In the present report, we showed that substituted (phenylamino)pyrrolo[1,2-a]quinoxaline-carboxylic acid derivatives are a novel class of potent inhibitors of the human protein kinase CK2. A set of 15 compounds was prepared and tested for their inhibitory activity. New inhibitors with $\mathrm{IC}_{50}$ in the micro- and sub-micromolar range were identified. The most promising compound, the 4-[(3chlorophenyl)amino]pyrrolo[1,2-a]quinoxaline-3-carboxylic acid 1c, inhibited human $\mathrm{CK} 2$ with an $\mathrm{IC}_{50}$ of $49 \mathrm{nM}$. Taken together, these results show that pyrrolo[1,2-a]quinoxalines, such as $\mathbf{1 c}$, are a promising starting point for the further development and optimization of potent CK2 inhibitors. Moreover, it would be interesting to enlarge the biological evaluation of the most active pyrrolo[1,2- $a]$ quinoxaline derivatives by measuring the inhibition of endogenous intracellular CK2 activity in leukemic cell lines in comparison with CX-4945.

\section{Experimental}

\subsection{Chemistry}

Commercially reagents were used as received without additional purification. Melting points were determined with an SMLUX-POL Leitz hot-stage microscope and are uncorrected. IR spectra were recorded on an NICOLET 380FT-IR spectrophotometer. NMR spectra were recorded with tetramethylsilane as an internal standard using a BRUKER AVANCE 300 spectrometer. Splitting patterns have been designated as follows: $s$ = singlet; bs = broad singlet; $\mathrm{d}=$ doublet; $\mathrm{t}=$ triplet; $\mathrm{q}=$ quartet; $\mathrm{dd}=$ double doublet; $\mathrm{m}=$ multiplet. Analytical TLC were carried out on 0.25 precoated silica gel plates (POLYGRAM SIL G/UV $\mathrm{UV}_{254}$ ) and visualization of compounds after UV light irradiation. Silica gel 60 (70-230 mesh) was used for column chromatography. Elemental analyses were found within $\pm 0.4 \%$ of the theoretical values.

\subsubsection{Diethyl 1-(2-nitrophenyl)pyrrole-2,3-dicarboxylate (4)}

To a solution of diethyl pyrrole-2,3-dicarboxylate 5 (4.83 $\mathrm{mmol})$ in $15 \mathrm{~mL}$ of DMF was added cesium carbonate $(5.80 \mathrm{mmol})$. The mixture was stirred at room temperature for $10 \mathrm{~min}$, then 1-fluoro2-nitrobenzene $(7.25 \mathrm{mmol}$ ) was refluxed for $1 \mathrm{~h} 30 \mathrm{~min}$, then was diluted in AcOEt $(50 \mathrm{~mL})$. The organic layer was washed with water $(2 \times 30 \mathrm{~mL})$, then brine $(40 \mathrm{~mL})$ and dried over sodium sulfate. The organic layer was concentrated under vacuo to give a brown oil. After triturating in $\mathrm{Et}_{2} \mathrm{O}$ a solid was obtained and filtered off, washed with $\mathrm{Et}_{2} \mathrm{O}$ and dried to give the desired product 4. Orange oil (92\%). IR ( $\mathrm{KBr}) 1700$ and $1690(\mathrm{C}=\mathrm{O}) .{ }^{1} \mathrm{H}$ NMR $\left(\mathrm{CDCl}_{3}\right) \delta: 8.06$ (dd, $1 \mathrm{H}, J=7.80$ and $\left.1.80 \mathrm{~Hz}, \mathrm{H}-3^{\prime}\right), 7.74-7.56\left(\mathrm{~m}, 2 \mathrm{H}, \mathrm{H}-4^{\prime}\right.$ and $\mathrm{H}-5^{\prime}$ ), $7.40\left(\mathrm{dd}, 1 \mathrm{H}, J=7.80\right.$ and $\left.1.80 \mathrm{~Hz}, \mathrm{H}-6^{\prime}\right), 6.83(\mathrm{~d}, 1 \mathrm{H}, J=3.00 \mathrm{~Hz}, \mathrm{H}-$ 5), $6.69(\mathrm{~d}, 1 \mathrm{H}, J=3.00 \mathrm{~Hz}, \mathrm{H}-4), 4.32\left(\mathrm{q}, 2 \mathrm{H}, J=7.20 \mathrm{~Hz}, \mathrm{OCH}_{2}\right), 4.10$ (q, $\left.2 \mathrm{H}, J=7.20 \mathrm{~Hz}, \mathrm{OCH}_{2}\right), 1.36\left(\mathrm{t}, 3 \mathrm{H}, J=7.20 \mathrm{~Hz}, \mathrm{CH}_{3}\right), 1.12(\mathrm{t}, 3 \mathrm{H}$, $J=7.20 \mathrm{~Hz}, \mathrm{CH}_{3}$ ). Anal. Calcd. for $\mathrm{C}_{16} \mathrm{H}_{16} \mathrm{~N}_{2} \mathrm{O}_{6}: \mathrm{C}, 57.83 ; \mathrm{H}, 4.85 ; \mathrm{N}$, 8.43. Found: C, 57.66; H, 5.03; N, 8.32.

6.1.2. General procedure for methyl 1-(4-ethoxycarbonyl-2nitrophenyl)pyrrole-2-carboxylate (6a) and methyl 1-(5-ethoxycarbonyl-2-nitrophenyl)pyrrole-2-carboxylate (6b)

To a solution of methyl pyrrole-2-carboxylate $(24.6 \mathrm{mmol})$ in $85 \mathrm{~mL}$ of DMF was added cesium carbonate $(29.5 \mathrm{mmol})$. 
The mixture was stirred at room temperature for $10 \mathrm{~min}$, then ethyl 4-fluoro-3-nitrobenzoate or ethyl 3-fluoro-4-nitrobenzoate (7.25 mmol) was added. The reaction mixture was refluxed for $1 \mathrm{~h} 30 \mathrm{~min}$ or $4 \mathrm{~h}$ (in case of $\mathbf{6 b}$ ), then was diluted in AcOEt ( $100 \mathrm{~mL}$ ). The organic layer was washed with water $(2 \times 60 \mathrm{~mL})$, then brine $(70 \mathrm{~mL})$ and dried over sodium sulfate. The organic layer was concentrated under vacuo to give a brown oil. After triturating in $\mathrm{Et}_{2} \mathrm{O}$ a solid was obtained and filtered off, washed with $\mathrm{Et}_{2} \mathrm{O}$ and dried to give the desired product $\mathbf{6}$.

6.1.2.1. Methyl 1-(4-ethoxycarbonyl-2-nitrophenyl)pyrrole-2carboxylate (6a). Yellow crystals (62\%); mp $77{ }^{\circ} \mathrm{C}$. IR (KBr) 1712 $(\mathrm{C}=\mathrm{O}) .{ }^{1} \mathrm{H}$ NMR $\left(\mathrm{CDCl}_{3}\right) \delta: 8.76\left(\mathrm{~d}, 1 \mathrm{H}, J=2.00 \mathrm{~Hz}, \mathrm{H}-3^{\prime}\right), 8.36(\mathrm{dd}$, $1 \mathrm{H}, J=8.10$ and $\left.2.00 \mathrm{~Hz}, \mathrm{H}-5^{\prime}\right), 7.52\left(\mathrm{~d}, 1 \mathrm{H}, J=8.10 \mathrm{~Hz}, \mathrm{H}-6^{\prime}\right), 7.15$ $(\mathrm{dd}, 1 \mathrm{H}, J=3.95$ and $1.65 \mathrm{~Hz}, \mathrm{H}-5), 6.95(\mathrm{dd}, 1 \mathrm{H}, J=2.85$ and $1.65 \mathrm{~Hz}$, $\mathrm{H}-3), 6.43(\mathrm{dd}, 1 \mathrm{H}, J=3.90$ and $2.85 \mathrm{~Hz}, \mathrm{H}-4), 4.47(\mathrm{q}, 2 \mathrm{H}$, $\left.J=7.20 \mathrm{~Hz}, \mathrm{OCH}_{2}\right), 3.70\left(\mathrm{~s}, 3 \mathrm{H}, \mathrm{OCH}_{3}\right), 1.45\left(\mathrm{t}, 3 \mathrm{H}, J=7.20 \mathrm{~Hz}, \mathrm{CH}_{3}\right)$. Anal. Calcd. for $\mathrm{C}_{15} \mathrm{H}_{14} \mathrm{~N}_{2} \mathrm{O}_{6}$ : C, 56.60; H, 4.43; N, 8.80. Found: $\mathrm{C}$, $56.81 ; \mathrm{H}, 4.29$; N, 8.96.

6.1.2.2. Methyl 1-(5-ethoxycarbonyl-2-nitrophenyl)pyrrole-2carboxylate (6b). Beige crystals (24\%); mp $117{ }^{\circ} \mathrm{C}$. IR (KBr) 1710 $(\mathrm{C}=\mathrm{O}) .{ }^{1} \mathrm{H}$ NMR $\left(\mathrm{CDCl}_{3}\right) \delta: 8.26\left(\mathrm{dd}, 1 \mathrm{H}, J=8.40\right.$ and $\left.1.80 \mathrm{~Hz}, \mathrm{H}-4^{\prime}\right)$, $8.15\left(\mathrm{~d}, 1 \mathrm{H}, J=8.40 \mathrm{~Hz}, \mathrm{H}-3^{\prime}\right), 8.09\left(\mathrm{~d}, 1 \mathrm{H}, J=1.80 \mathrm{~Hz}, \mathrm{H}-6^{\prime}\right), 7.15(\mathrm{dd}$, $1 \mathrm{H}, J=3.90$ and $1.80 \mathrm{~Hz}, \mathrm{H}-3), 6.97(\mathrm{dd}, 1 \mathrm{H}, J=2.70$ and $1.80 \mathrm{~Hz}, \mathrm{H}-$ 5), 6.43 (dd, $1 \mathrm{H}, J=3.90$ and $2.70 \mathrm{~Hz}, \mathrm{H}-4), 4.44(\mathrm{q}, 2 \mathrm{H}, J=7.20 \mathrm{~Hz}$, $\left.\mathrm{OCH}_{2}\right), 3.70\left(\mathrm{~s}, 3 \mathrm{H}, \mathrm{OCH}_{3}\right), 1.43\left(\mathrm{t}, 3 \mathrm{H}, J=7.20 \mathrm{~Hz}, \mathrm{CH}_{3}\right)$. Anal. Calcd. for $\mathrm{C}_{15} \mathrm{H}_{14} \mathrm{~N}_{2} \mathrm{O}_{6}$ : C, 56.60; H, 4.43; N, 8.80. Found: C, 56.52; H, 4.64; N, 9.10.

\subsubsection{Ethyl 2-amino-3-nitrobenzoate (7)}

A mixture of 2-amino-3-nitrobenzoic acid ( $18 \mathrm{mmol}$ ) and $50 \mathrm{~mL}$ of thionyl chloride was refluxed for $3 \mathrm{~h}$. The mixture was then evaporated in vacuo to dryness and ethanol $(80 \mathrm{~mL})$ was added. The resulting solution was allowed to stir at room temperature for $15 \mathrm{~h}$. The ethanol was evaporated and water was added. A yellow solid was collected by filtration, washed with water and dried to give 7 . Yellow crystals (85\%); mp $88^{\circ} \mathrm{C}$. IR ( $\left.\mathrm{KBr}\right) 3380$ and $3290\left(\mathrm{NH}_{2}\right), 1690$ $(\mathrm{C}=\mathrm{O}) .{ }^{1} \mathrm{H}$ NMR $\left(\mathrm{CDCl}_{3}\right) \delta: 8.61\left(\mathrm{bs}, 2 \mathrm{H}, \mathrm{NH}_{2}\right), 8.52(\mathrm{dd}, 1 \mathrm{H}, J=8.40$ and $1.55 \mathrm{~Hz}, \mathrm{H}-6), 8.29(\mathrm{dd}, 1 \mathrm{H}, J=8.40$ and $1.55 \mathrm{~Hz}, \mathrm{H}-4), 6.67(\mathrm{t}$, $1 \mathrm{H}, J=8.40 \mathrm{~Hz}, \mathrm{H}-5), 4.40\left(\mathrm{q}, 2 \mathrm{H}, J=7.20 \mathrm{~Hz}, \mathrm{OCH}_{2}\right), 1.43(\mathrm{t}, 3 \mathrm{H}$, $J=7.20 \mathrm{~Hz}, \mathrm{CH}_{3}$ ). Anal. Calcd. for $\mathrm{C}_{9} \mathrm{H}_{10} \mathrm{~N}_{2} \mathrm{O}_{4}$ : C, 51.43; $\mathrm{H}, 4.80 ; \mathrm{N}$, 13.33. Found: C, $51.62 ; \mathrm{H}, 4.87 ; \mathrm{N}, 13.58$.

\subsubsection{Ethyl 3-nitro-2-pyrrol-1-ylbenzoate (8)}

Method A: A mixture of ethyl 2-amino-3-nitrobenzoate 7 (15 mmol) and 2,5-dimethoxytetrahydrofuran (16.6 mmol) in acetic acid $(40 \mathrm{~mL})$ was refluxed for $4 \mathrm{~h}$ with vigorous stirring. After cooling, the reaction mixture was poured into water. The mixture was then extracted twice with diethyl ether. The organic layer was dried over magnesium sulfate and evaporated to dryness under reduced pressure. The crude residue was then purified by column chromatography using AcOEt/cyclohexane (3/7, v/v) as eluent to give 8. Method B: To a solution of 3-nitro-2-pyrrol-1-ylbenzoic acid $9(24.6 \mathrm{mmol})$ in $80 \mathrm{~mL}$ of ethanol was added thionyl chloride (27 mmol). The reaction mixture was heated under reflux for $2 \mathrm{~h}$. Ethanol was evaporated under reduced pressure. The residue was triturated with water then extracted with ethyl acetate. The organic layer was washed with a saturated aqueous sodium bicarbonate solution, dried over sodium sulfate, charcoaled and evaporated to dryness. The crude residue was then purified by column chromatography using AcOEt/cyclohexane (3/7, v/v) as eluent to give 8 . Yellow oil (method A: 64\%; method B: 32\%). IR ( $\mathrm{KBr}) 1695(\mathrm{C}=\mathrm{O})$. ${ }^{1} \mathrm{H} \mathrm{NMR}\left(\mathrm{CDCl}_{3}\right) \delta: 8.02(\mathrm{dd}, 1 \mathrm{H}, J=7.80$ and $1.50 \mathrm{~Hz}, \mathrm{H}-6), 7.93(\mathrm{dd}$, $1 \mathrm{H}, J=7.80$ and $1.50 \mathrm{~Hz}, \mathrm{H}-4), 7.62(\mathrm{t}, 1 \mathrm{H}, J=7.80 \mathrm{~Hz}, \mathrm{H}-5), 6.72(\mathrm{dd}$,
$2 \mathrm{H}, J=2.10$ and $2.10 \mathrm{~Hz}, 2 \mathrm{H}-\alpha), 6.34(\mathrm{dd}, 2 \mathrm{H}, J=2.10$ and $2.10 \mathrm{~Hz}$, $2 \mathrm{H}-\beta), 4.15$ (q, $\left.2 \mathrm{H}, J=7.20 \mathrm{~Hz}, \mathrm{OCH}_{2}\right), 1.12\left(\mathrm{t}, 3 \mathrm{H}, J=7.20 \mathrm{~Hz}, \mathrm{CH}_{3}\right)$. Anal. Calcd. for $\mathrm{C}_{13} \mathrm{H}_{12} \mathrm{~N}_{2} \mathrm{O}_{4}$ : C, 60.00; $\mathrm{H}, 4.65 ; \mathrm{N}, 10.76$. Found: $\mathrm{C}$, 59.84; $\mathrm{H}, 4.51 ; \mathrm{N}, 10.92$.

\subsubsection{3-Nitro-2-pyrrol-1-ylbenzoic acid (9)}

A mixture of 2-amino-3-nitrobenzoic acid (27.5 mmol) and 2,5dimethoxytetrahydrofuran $(30 \mathrm{mmol})$ in acetic acid $(70 \mathrm{~mL})$ was refluxed for $1 \mathrm{~h}$ with vigourous stirring. After cooling, the reaction mixture was poured into water. The mixture was then extracted twice with diethyl ether. The organic layer was dried over sodium sulfate and evaporated to dryness under reduced pressure. The crude residue was recrystallized from petroleum ether to give $\mathbf{9}$. Brown crystals (89\%); mp $148^{\circ} \mathrm{C}$. IR ( $\left.\mathrm{KBr}\right) 3400-2560(\mathrm{COOH}), 1695$ $(\mathrm{C}=0) .{ }^{1} \mathrm{H}$ NMR $\left(\mathrm{CDCl}_{3}\right) \delta: 8.15(\mathrm{dd}, 1 \mathrm{H}, J=7.95$ and $1.50 \mathrm{~Hz}, \mathrm{H}-6)$, 7.97 (dd, $1 \mathrm{H}, J=7.95$ and $1.50 \mathrm{~Hz}, \mathrm{H}-4), 7.65(\mathrm{t}, 1 \mathrm{H}, J=7.95 \mathrm{~Hz}, \mathrm{H}-5)$, 6.81 (bs, $1 \mathrm{H}, \mathrm{COOH}), 6.73(\mathrm{dd}, 2 \mathrm{H}, J=2.10$ and $2.10 \mathrm{~Hz}, 2 \mathrm{H}-\alpha), 6.64$ (dd, $2 \mathrm{H}, J=2.10$ and $2.10 \mathrm{~Hz}, 2 \mathrm{H}-\beta$ ). Anal. Calcd. for $\mathrm{C}_{11} \mathrm{H}_{8} \mathrm{~N}_{2} \mathrm{O}_{4}$ : C, 56.90; H, 3.47; N, 12.06. Found: C, 57.10; H, 3.49; N, 11.84.

\subsubsection{Ethyl 3-amino-2-pyrrol-1-ylbenzoate (10)}

To a solution of ethyl 3-nitro-2-pyrrol-1-ylbenzoate 8 (8 $\mathrm{mmol})$ in ethanol $(40 \mathrm{~mL})$ was added $6.5 \mathrm{~mL}$ of a $2 \mathrm{M}$ aqueous solution of $\mathrm{CuSO}_{4}$. Sodium borohydride ( $40 \mathrm{mmol}$ ) was added portion-wise at $0{ }^{\circ} \mathrm{C}$ to the reaction mixture which was then stirred at room temperature for $1 \mathrm{~h}$. The reaction mixture was then diluted with ethyl acetate and filtered. The organic layer was separated, dried over $\mathrm{Na}_{2} \mathrm{SO}_{4}$ and evaporated to dryness under reduced pressure to give 10. Orange oil (90\%). IR (KBr) 3380 and $3290\left(\mathrm{NH}_{2}\right), 1695(\mathrm{C}=\mathrm{O}) .{ }^{1} \mathrm{H}$ NMR $\left(\mathrm{CDCl}_{3}\right) \delta: 7.29-7.21(\mathrm{~m}, 2 \mathrm{H}, \mathrm{H}-5$ and $\mathrm{H}-6), 6.93(\mathrm{dd}, 1 \mathrm{H}$, $J=7.40$ and $2.20 \mathrm{~Hz}, \mathrm{H}-4), 6.70(\mathrm{dd}, 2 \mathrm{H}, J=2.10$ and $2.10 \mathrm{~Hz}, 2 \mathrm{H}-\alpha)$, $6.35(\mathrm{dd}, 2 \mathrm{H}, J=2.10$ and $2.10 \mathrm{~Hz}, 2 \mathrm{H}-\beta), 4.10(\mathrm{q}, 2 \mathrm{H}, J=7.20 \mathrm{~Hz}$, $\mathrm{OCH}_{2}$ ), 3.73 (bs, $2 \mathrm{H}, \mathrm{NH}_{2}$ ), 1.11 (t, $3 \mathrm{H}, J=7.20 \mathrm{~Hz}, \mathrm{CH}_{3}$ ). Anal. Calcd. for $\mathrm{C}_{13} \mathrm{H}_{14} \mathrm{~N}_{2} \mathrm{O}_{2}$ : C, 67.81; $\mathrm{H}, 6.13 ; \mathrm{N}, 12.17$. Found: C, 68.03; $\mathrm{H}, 6.27$; $\mathrm{N}, 12.30$.

\subsubsection{General procedure for ethyl 4-oxo-5H-pyrrolo[1,2-a]} quinoxaline-carboxylates (2b-d) and ethyl 4-oxo-2-(3-pyridyl)5H-pyrrolo[1,2-a]quinoxaline-7-carboxylate (2f)

A suspension of $\mathbf{4}$ or $\mathbf{6 a , b}$ or $\mathbf{2 3}(12.3 \mathrm{mmol})$ and iron powder $(49.1 \mathrm{mmol})$ in $55 \mathrm{~mL}$ of acetic acid was heated under reflux for $2 \mathrm{~h}$. The reaction mixture was cooled, suspended in $150 \mathrm{~mL}$ of a $1 \mathrm{M}$ aqueous solution of $\mathrm{HCl}$, agitated, then filtered off, washed with $\mathrm{HCl}$ $1 \mathrm{M}(80 \mathrm{~mL})$, water, $\mathrm{Et}_{2} \mathrm{O}$ and dried to give a fluffy white solid.

6.1.7.1. Ethyl 4-oxo-5H-pyrrolo[1,2-a]quinoxaline-3-carboxylate (2b). Beige crystals (57\%); mp $225{ }^{\circ} \mathrm{C}$. IR (KBr) 3200-2800 (CONH lactame), 1725 (COO), 1670 (CON). ${ }^{1} \mathrm{H}$ NMR (DMSO-d 6 ) $\delta: 11.46(\mathrm{~s}$, $1 \mathrm{H}, \mathrm{NH}), 8.25$ (d, $1 \mathrm{H}, J=2.85 \mathrm{~Hz}, \mathrm{H}-1), 8.12(\mathrm{~d}, 1 \mathrm{H}, J=8.10 \mathrm{~Hz}, \mathrm{H}-9)$, 7.35-7.30 (m, 2H, H-6 and H-8), 7.26-7.21 (m, 1H, H-7), $6.96(\mathrm{~d}, 1 \mathrm{H}$, $J=2.85 \mathrm{~Hz}, \mathrm{H}-2), 4.26\left(\mathrm{q}, 2 \mathrm{H}, J=7.20 \mathrm{~Hz}, \mathrm{OCH}_{2}\right), 1.30(\mathrm{t}, 3 \mathrm{H}$, $J=7.20 \mathrm{~Hz}, \mathrm{CH}_{3}$ ). Anal. Calcd. for $\mathrm{C}_{14} \mathrm{H}_{12} \mathrm{~N}_{2} \mathrm{O}_{3}$ : C, 65.62; $\mathrm{H}, 4.72 ; \mathrm{N}$, 10.93. Found: C, 65.49; H, 4.78; N, 11.04 .

6.1.7.2. Ethyl 4-oxo-5H-pyrrolo[1,2-a]quinoxaline-7-carboxylate (2c). White crystals (92\%); mp $251^{\circ} \mathrm{C}$. IR (KBr) 3200-2800 (CONH lactame), 1710 (COO), 1650 (CON). ${ }^{1} \mathrm{H}$ NMR (DMSO-d $\left.d_{6}\right) \delta: 11.42(\mathrm{~s}, 1 \mathrm{H}$, $\mathrm{NH}), 8.25(\mathrm{~d}, 1 \mathrm{H}, J=1.95 \mathrm{~Hz}, \mathrm{H}-6), 8.15(\mathrm{~d}, 1 \mathrm{H}, J=8.20 \mathrm{~Hz}, \mathrm{H}-9), 7.94-$ $7.92(\mathrm{~m}, 1 \mathrm{H}, \mathrm{H}-1), 7.74(\mathrm{dd}, 1 \mathrm{H}, J=8.20$ and $1.95 \mathrm{~Hz}, \mathrm{H}-8), 7.09-7.07$ $(\mathrm{m}, 1 \mathrm{H}, \mathrm{H}-3), 6.76-6.73(\mathrm{~m}, 1 \mathrm{H}, \mathrm{H}-2), 4.34\left(\mathrm{q}, 2 \mathrm{H}, J=7.20 \mathrm{~Hz}, \mathrm{OCH}_{2}\right)$, $1.33\left(\mathrm{t}, 3 \mathrm{H}, J=7.20 \mathrm{~Hz}, \mathrm{CH}_{3}\right)$. Anal. Calcd. for $\mathrm{C}_{14} \mathrm{H}_{12} \mathrm{~N}_{2} \mathrm{O}_{3}: \mathrm{C}, 65.62 ; \mathrm{H}$, 4.72; N, 10.93. Found: C, 65.74; H, 4.58; N, 11.09.

6.1.7.3. Ethyl 4-oxo-5H-pyrrolo[1,2-a]quinoxaline-8-carboxylate (2d). Beige crystals (28\%); $\mathrm{mp}>275{ }^{\circ} \mathrm{C}$. IR (KBr) $3200-2800$ 
(CONH lactame), 1710 (COO), 1650 (CON). ${ }^{1} \mathrm{H}$ NMR (DMSO-d $\left.)_{6}\right) \delta$ : $11.60(\mathrm{~s}, 1 \mathrm{H}, \mathrm{NH}), 8.53$ (d, $1 \mathrm{H}, J=1.80 \mathrm{~Hz}, \mathrm{H}-9), 8.38$ (dd, $1 \mathrm{H}, J=2.90$ and $1.90 \mathrm{~Hz}, \mathrm{H}-1$ ), 7.87 (dd, $1 \mathrm{H}, J=8.40$ and $1.80 \mathrm{~Hz}, \mathrm{H}-7$ ), 7.38 (d, $1 \mathrm{H}, J=8.40 \mathrm{~Hz}, \mathrm{H}-6), 7.08$ (dd, $1 \mathrm{H}, J=3.95$ and $1.90 \mathrm{~Hz}, \mathrm{H}-3$ ), 6.71 (dd, $1 \mathrm{H}, J=3.95$ and $2.90 \mathrm{~Hz}, \mathrm{H}-2) 4.35\left(\mathrm{q}, 2 \mathrm{H}, J=6.90 \mathrm{~Hz}, \mathrm{OCH}_{2}\right.$ ), $1.36\left(\mathrm{t}, 3 \mathrm{H}, J=6.90 \mathrm{~Hz}, \mathrm{CH}_{3}\right)$. Anal. Calcd. for $\mathrm{C}_{14} \mathrm{H}_{12} \mathrm{~N}_{2} \mathrm{O}_{3}$ : C, 65.62; $\mathrm{H}, 4.72 ; \mathrm{N}, 10.93$. Found: $\mathrm{C}, 65.51 ; \mathrm{H}, 4.80 ; \mathrm{N}, 11.15$.

6.1.7.4. Ethyl 4-oxo-2-(3-pyridyl)-5H-pyrrolo[1,2-a]quinoxaline-7carboxylate (2f). Beige crystals (92\%); $\mathrm{mp}>270{ }^{\circ} \mathrm{C}$. IR (KBr) 34003150 (CONH lactame), 1710 (COO), 1685 (CON). ${ }^{1} \mathrm{H}$ NMR (DMSO-d $\left.d_{6}\right)$ $\delta: 11.58(\mathrm{~s}, 1 \mathrm{H}, \mathrm{NH}), 9.34-9.33(\mathrm{~m}, 1 \mathrm{H}, \mathrm{H}-1), 9.11(\mathrm{~d}, 1 \mathrm{H}, J=1.80 \mathrm{~Hz}, \mathrm{H}-$ 6), 8.76-8.73 (m, $2 \mathrm{H}, \mathrm{H}-6^{\prime}$ and $\left.\mathrm{H}-4^{\prime}\right), 8.16(\mathrm{~d}, 1 \mathrm{H}, J=8.40 \mathrm{~Hz}, \mathrm{H}-9)$, $7.97-7.93\left(\mathrm{~m}, 2 \mathrm{H}, \mathrm{H}-8\right.$ and $\left.\mathrm{H}-2^{\prime}\right), 7.85(\mathrm{dd}, 1 \mathrm{H}, J=7.90$ and $5.00 \mathrm{~Hz}, \mathrm{H}-$ $\left.5^{\prime}\right), 7.81-7.80(\mathrm{~m}, 1 \mathrm{H}, \mathrm{H}-3), 4.36\left(\mathrm{q}, 2 \mathrm{H}, J=6.90 \mathrm{~Hz}, \mathrm{OCH}_{2}\right), 1.35(\mathrm{t}, 3 \mathrm{H}$, $\left.J=6.90 \mathrm{~Hz}, \mathrm{CH}_{3}\right)$. Anal. Calcd. for $\mathrm{C}_{19} \mathrm{H}_{15} \mathrm{~N}_{3} \mathrm{O}_{3}: \mathrm{C}, 68.46 ; \mathrm{H}, 4.54 ; \mathrm{N}$, 12.61. Found: C, 68.33; H, 4.72; N, 12.78.

\subsubsection{Ethyl 4-oxo-5H-pyrrolo[1,2-a]quinoxaline-9-carboxylate (2e)}

To a solution of compound $\mathbf{1 0}(7 \mathrm{mmol})$ in toluene $(30 \mathrm{~mL})$ was added triphosgene $(2.34 \mathrm{mmol})$. The reaction mixture was refluxed for $4 \mathrm{~h}$, and nitrogen was bubbled in to drive off excess of phosgene. The solution was then set aside for $10 \mathrm{~min}$. The heavy crystalline precipitate was filtered off and washed with diethyl ether to give 2e. White crystals (75\%); mp $243{ }^{\circ} \mathrm{C}$. IR (KBr) 3400-3950 (CONH lactame), 1720 (COO), 1660 (CON). ${ }^{1} \mathrm{H}$ NMR (DMSO-d 6 ) $\delta: 11.52$ (s, $1 \mathrm{H}, \mathrm{NH}), 7.47(\mathrm{dd}, 1 \mathrm{H}, J=3.00$ and $1.20 \mathrm{~Hz}, \mathrm{H}-1), 7.45(\mathrm{dd}, 1 \mathrm{H}$, $J=7.80$ and $1.80 \mathrm{~Hz}, \mathrm{H}-6), 7.37$ (t, $1 \mathrm{H}, J=7.80 \mathrm{~Hz}, \mathrm{H}-7), 7.30$ (dd, $1 \mathrm{H}$, $J=7.80$ and $1.80 \mathrm{~Hz}, \mathrm{H}-8), 7.11$ (dd, $1 \mathrm{H}, J=3.90$ and $1.20 \mathrm{~Hz}, \mathrm{H}-3$ ), $6.70(\mathrm{dd}, 1 \mathrm{H}, J=3.90$ and $3.00 \mathrm{~Hz}, \mathrm{H}-2), 4.46(\mathrm{q}, 2 \mathrm{H}, J=7.10 \mathrm{~Hz}$, $\left.\mathrm{OCH}_{2}\right), 1.33\left(\mathrm{t}, 3 \mathrm{H}, J=7.10 \mathrm{~Hz}, \mathrm{CH}_{3}\right)$. Anal. Calcd. for $\mathrm{C}_{14} \mathrm{H}_{12} \mathrm{~N}_{2} \mathrm{O}_{3}: \mathrm{C}$, 65.62; H, 4.72; N, 10.93. Found: C, 65.83; H, 4.85; N, 11.10 .

\subsubsection{General procedure for ethyl 4-chloropyrrolo[1,2-a]} quinoxaline-carboxylates (11b-e) and ethyl 4-chloro-2-(3-pyridyl) pyrrolo[1,2-a]quinoxaline-7-carboxylate (11f)

A solution of $5 \mathrm{H}$-pyrrolo[1,2-a]quinoxalin-4-one $\mathbf{2 a}-\mathbf{f}(4 \mathrm{mmol})$ in $\mathrm{POCl}_{3}(8 \mathrm{~mL})$ was refluxed for $2 \mathrm{~h}$. After removing excess of reactive under vacuum, the residue was carefully dissolved in water at $0{ }^{\circ} \mathrm{C}$ and the resulting solution was made basic with sodium carbonate. The precipitate was filtered, dried and recrystallized from ethyl acetate to give $\mathbf{1 1}$.

6.1.9.1. Ethyl 4-chloropyrrolo[1,2-a]quinoxaline-3-carboxylate (11b). White crystals (89\%); mp $100{ }^{\circ} \mathrm{C}$. IR (KBr) 1710 (COO). ${ }^{1} \mathrm{H}$ NMR $\left(\mathrm{CDCl}_{3}\right) \delta: 7.94(\mathrm{~d}, 1 \mathrm{H}, J=2.55 \mathrm{~Hz}, \mathrm{H}-1), 7.92(\mathrm{~d}, 1 \mathrm{H}, J=8.10 \mathrm{~Hz}, \mathrm{H}-9)$, $7.86(\mathrm{~d}, 1 \mathrm{H}, J=8.10 \mathrm{~Hz}, \mathrm{H}-6), 7.62(\mathrm{t}, 1 \mathrm{H}, J=8.10 \mathrm{~Hz}, \mathrm{H}-8), 7.52(\mathrm{t}, 1 \mathrm{H}$, $J=8.10 \mathrm{~Hz}, \mathrm{H}-7), 7.25(\mathrm{~d}, 1 \mathrm{H}, J=2.55 \mathrm{~Hz}, \mathrm{H}-2), 4.44(\mathrm{q}, 2 \mathrm{H}, J=7.20 \mathrm{~Hz}$, $\left.\mathrm{OCH}_{2}\right), 1.45\left(\mathrm{t}, 3 \mathrm{H}, J=7.20 \mathrm{~Hz}, \mathrm{CH}_{3}\right)$. Anal. Calcd. for $\mathrm{C}_{14} \mathrm{H}_{11} \mathrm{ClN}_{2} \mathrm{O}_{2}: \mathrm{C}$, $61.21 ; \mathrm{H}, 4.04$; N, 10.20. Found: C, 61.13; H, 3.82; N, 10.28.

6.1.9.2. Ethyl 4-chloropyrrolo[1,2-a]quinoxaline-7-carboxylate (11c). White crystals (82\%); mp $137{ }^{\circ} \mathrm{C}$. IR (KBr) 1715 (COO). ${ }^{1} \mathrm{H}$ NMR $\left(\mathrm{CDCl}_{3}\right) \delta: 8.64(\mathrm{~d}, 1 \mathrm{H}, J=2.00 \mathrm{~Hz}, \mathrm{H}-6), 8.24(\mathrm{dd}, 1 \mathrm{H}, J=8.10$ and $2.00 \mathrm{~Hz}, \mathrm{H}-8), 8.05-8.04(\mathrm{~m}, 1 \mathrm{H}, \mathrm{H}-1), 7.89(\mathrm{~d}, 1 \mathrm{H}, J=8.10 \mathrm{~Hz}, \mathrm{H}-9)$, 7.14-7.12 (m, 1H, H-3), 6.99-6.96 (m, 1H, H-2), $4.45(\mathrm{q}, 2 \mathrm{H}$, $\left.J=7.20 \mathrm{~Hz}, \mathrm{OCH}_{2}\right), 1.45$ (t, $\left.3 \mathrm{H}, J=7.20 \mathrm{~Hz}, \mathrm{CH}_{3}\right)$. Anal. Calcd. for $\mathrm{C}_{14} \mathrm{H}_{11} \mathrm{ClN}_{2} \mathrm{O}_{2}$ : C, 61.21; $\mathrm{H}, 4.04 ; \mathrm{N}, 10.20$. Found: $\mathrm{C}, 61.34 ; \mathrm{H}, 3.92 ; \mathrm{N}$, 10.36 .

6.1.9.3. Ethyl 4-chloropyrrolo[1,2-a]quinoxaline-8-carboxylate (11d). White crystals (80\%); mp $161{ }^{\circ} \mathrm{C}$. IR (KBr) 1705 (COO). ${ }^{1} \mathrm{H}$ NMR $\left(\mathrm{CDCl}_{3}\right) \delta: 8.57(\mathrm{~d}, 1 \mathrm{H}, J=1.80 \mathrm{~Hz}, \mathrm{H}-9), 8.14-8.11(\mathrm{~m}, 1 \mathrm{H}, \mathrm{H}-7), 7.95$ $(\mathrm{d}, 1 \mathrm{H}, J=8.70 \mathrm{~Hz}, \mathrm{H}-6), 7.13(\mathrm{dd}, 1 \mathrm{H}, J=3.90$ and $1.90 \mathrm{~Hz}, \mathrm{H}-3), 6.96$ (dd, $1 \mathrm{H}, J=3.90$ and $3.00 \mathrm{~Hz}, \mathrm{H}-2), 4.48\left(\mathrm{q}, 2 \mathrm{H}, J=7.20 \mathrm{~Hz}, \mathrm{OCH}_{2}\right.$ ), $1.48\left(\mathrm{t}, 3 \mathrm{H}, J=7.20 \mathrm{~Hz}, \mathrm{CH}_{3}\right)$. Anal. Calcd. for $\mathrm{C}_{14} \mathrm{H}_{11} \mathrm{ClN}_{2} \mathrm{O}_{2}: \mathrm{C}, 61.21$; H, 4.04; N, 10.20. Found: C, 61.09; H, 3.87; N, 10.32 .

6.1.9.4. Ethyl 4-chloropyrrolo[1,2-a]quinoxaline-9-carboxylate (11e). White crystals (80\%); mp $84{ }^{\circ} \mathrm{C}$. IR ( $\left.\mathrm{KBr}\right) 1695(\mathrm{COO}) .{ }^{1} \mathrm{H}$ NMR $\left(\mathrm{CDCl}_{3}\right) \delta: 8.02(\mathrm{dd}, 1 \mathrm{H}, J=7.80$ and $1.50 \mathrm{~Hz}, \mathrm{H}-6), 7.85(\mathrm{dd}, 1 \mathrm{H}$, $J=3.00$ and $1.20 \mathrm{~Hz}, \mathrm{H}-1), 7.69(\mathrm{dd}, 1 \mathrm{H}, J=7.80$ and $1.50 \mathrm{~Hz}, \mathrm{H}-8)$, $7.48(\mathrm{t}, 1 \mathrm{H}, J=7.80 \mathrm{~Hz}, \mathrm{H}-7), 7.13(\mathrm{dd}, 1 \mathrm{H}, J=3.90$ and $1.20 \mathrm{~Hz}, \mathrm{H}-3)$, $6.89(\mathrm{dd}, 1 \mathrm{H}, J=3.90$ and $3.00 \mathrm{~Hz}, \mathrm{H}-2), 4.55(\mathrm{q}, 2 \mathrm{H}, J=6.90 \mathrm{~Hz}$, $\left.\mathrm{OCH}_{2}\right), 1.46\left(\mathrm{t}, 3 \mathrm{H}, \mathrm{J}=6.90 \mathrm{~Hz}, \mathrm{CH}_{3}\right)$. Anal. Calcd. for $\mathrm{C}_{14} \mathrm{H}_{11} \mathrm{ClN}_{2} \mathrm{O}_{2}$ : C, 61.21; H, 4.04; N, 10.20. Found: C, 61.44; H, 4.19; N, 10.15 .

6.1.9.5. Ethyl 4-chloro-2-(3-pyridyl)pyrrolo[1,2-a]quinoxaline-7carboxylate (11f). White crystals $(68 \%) ; \operatorname{mp~} 259{ }^{\circ} \mathrm{C}$. IR $(\mathrm{KBr}) 1710$ (COO). ${ }^{1} \mathrm{H}$ NMR (DMSO-d 6 ) $\delta: 9.40(\mathrm{~d}, 1 \mathrm{H}, J=1.20 \mathrm{~Hz}, \mathrm{H}-1), 9.23(\mathrm{~d}$, $1 \mathrm{H}, J=1.80 \mathrm{~Hz}, \mathrm{H}-6), 8.61-8.58\left(\mathrm{~m}, 1 \mathrm{H}, \mathrm{H}-4^{\prime}\right), 8.47-8.43(\mathrm{~m}, 2 \mathrm{H}, \mathrm{H}-9$ and $\left.\mathrm{H}^{\prime} 6^{\prime}\right), 8.36\left(\mathrm{~d}, 1 \mathrm{H}, J=1.80 \mathrm{~Hz}, \mathrm{H}-2^{\prime}\right), 8.23(\mathrm{dd}, 1 \mathrm{H}, J=8.40$ and $1.80 \mathrm{~Hz}, \mathrm{H}-8), 7.78$ (d, $1 \mathrm{H}, J=1.20 \mathrm{~Hz}, \mathrm{H}-3), 7.65-7.60\left(\mathrm{~m}, 1 \mathrm{H}, \mathrm{H}-5^{\prime}\right)$, 4.39 (q, $\left.2 \mathrm{H}, J=6.90 \mathrm{~Hz}, \mathrm{OCH}_{2}\right), 1.38\left(\mathrm{t}, 3 \mathrm{H}, J=6.90 \mathrm{~Hz}, \mathrm{CH}_{3}\right)$. Anal. Calcd. for $\mathrm{C}_{19} \mathrm{H}_{14} \mathrm{ClN}_{3} \mathrm{O}_{2}$ : C, 64.87; $\mathrm{H}, 4.01 ; \mathrm{N}, 11.94$. Found: $\mathrm{C}, 65.03$; $\mathrm{H}, 4.08 ; \mathrm{N}, 12.14$.

6.1.10. General procedure for ethyl 4-[(3-substituted-phenyl)amino] pyrrolo[1,2-a]quinoxaline-carboxylates 12a-j and ethyl 7-[(3-substituted-phenyl)amino]pyrrolo[1,2-a]quinoxaline-4-carboxylates $\mathbf{1 2 k}, \mathbf{l}$ and ethyl 4-[(3-substituted-phenyl)amino]-2-(3-pyridyl) pyrrolo[1,2-a]quinoxaline-7-carboxylates $\mathbf{1 2 m , n}$

Method A: Ethyl 4-chloropyrrolo[1,2-a]quinoxaline-carboxylates 11b-e or ethyl 4-chloro-2-(3-pyridyl)pyrrolo[1,2-a]quinoxaline-7carboxylate (11f) $(1.5 \mathrm{mmol}), 3$-substituted aniline $(1.95 \mathrm{mmol})$, and DMF $(10 \mathrm{~mL})$ were mixed and heated at reflux for $2 \mathrm{~h} 30 \mathrm{~min}$. The reaction mixture was then diluted with ethyl acetate. The organic layer was washed with water then with brine, separated, dried over $\mathrm{Na}_{2} \mathrm{SO}_{4}$ and evaporated to dryness under reduced pressure. The crude residue was triturated in diethyl ether, filtered and then purified by column chromatography using AcOEt/cyclohexane (3/7, $\mathrm{v} / \mathrm{v}$ ) as eluent to give $\mathbf{1 2 a}-\mathbf{j}$ and $\mathbf{1 2 m}, \mathbf{n}$. Method $\mathrm{B}$ : A mixture of 4 chloropyrrolo[1,2-a]quinoxalines $\mathbf{1 1 a} / \mathbf{c} / \mathbf{e} / \mathbf{g} / \mathbf{i} / \mathbf{m}$ or 7 -bromopyrrolo [1,2-a]quinoxaline (16) (1 mmol), 3-substituted aniline $(1.2 \mathrm{mmol})$, $\mathrm{Cs}_{2} \mathrm{CO}_{3}(1.4 \mathrm{mmol}), \mathrm{Pd}(\mathrm{OAc})_{2}(0.05 \mathrm{mmol})$ and $\operatorname{BINAP}(0.075 \mathrm{mmol})$ in $5 \mathrm{~mL}$ of toluene was heated at $100{ }^{\circ} \mathrm{C}$ for $20 \mathrm{~h}$. The reaction mixture was allowed to cool to room temperature, diluted with dichloromethane and filtered through a pad of Celite and the filter cake was washed with dichloromethane $(\times 3)$. Concentration and flash chromatography on silica gel using AcOEt/cyclohexane (3/7, $\mathrm{v} / \mathrm{v}$ ) as eluent afforded $\mathbf{1 2 a} / \mathbf{c} / \mathbf{e} / \mathbf{g} / \mathbf{i} / \mathbf{m}$ and $\mathbf{1 2 k}, \mathbf{l}$, respectively.

6.1.10.1. Ethyl 4-[(3-chlorophenyl)amino]pyrrolo[1,2-a]quinoxaline2-carboxylate (12a). White crystals (method A: 44\%; method B: 51\%); mp $183{ }^{\circ} \mathrm{C}$. IR (KBr) $3390(\mathrm{NH}), 1690$ (COO). ${ }^{1} \mathrm{H}$ NMR (DMSO$\left.d_{6}\right) \delta: 9.45(\mathrm{~s}, 1 \mathrm{H}, \mathrm{NH}), 8.93(\mathrm{~d}, 1 \mathrm{H}, J=1.50 \mathrm{~Hz}, \mathrm{H}-1), 8.35(\mathrm{~d}, 1 \mathrm{H}$, $\left.J=1.80 \mathrm{~Hz}, \mathrm{H}-2^{\prime}\right), 8.32(\mathrm{dd}, 1 \mathrm{H}, J=8.00$ and $1.40 \mathrm{~Hz}, \mathrm{H}-9), 8.06(\mathrm{dd}$, $1 \mathrm{H}, J=8.20$ and $\left.1.65 \mathrm{~Hz}, \mathrm{H}-6^{\prime}\right), 7.88(\mathrm{~d}, 1 \mathrm{H}, J=1.50 \mathrm{~Hz}, \mathrm{H}-3), 7.64$ (dd, $1 \mathrm{H}, J=8.00$ and $1.40 \mathrm{~Hz}, \mathrm{H}-6), 7.46-7.33(\mathrm{~m}, 3 \mathrm{H}, \mathrm{H}-7, \mathrm{H}-8$ and $\left.\mathrm{H}-5^{\prime}\right), 7.11-7.07\left(\mathrm{~m}, 1 \mathrm{H}, \mathrm{H}-4^{\prime}\right), 4.36\left(\mathrm{q}, 2 \mathrm{H}, J=7.20 \mathrm{~Hz}, \mathrm{OCH}_{2}\right), 1.37$ (t, $\left.3 \mathrm{H}, J=7.20 \mathrm{~Hz}, \mathrm{CH}_{3}\right)$. Anal. Calcd. for $\mathrm{C}_{20} \mathrm{H}_{16} \mathrm{ClN}_{3} \mathrm{O}_{2}$ : C, 65.67; $\mathrm{H}$, 4.41 ; N, 11.49. Found: C, 65.78; H, 4.47; N, 11.62.

6.1.10.2. Ethyl 4-[(3-ethynylphenyl)amino]pyrrolo[1,2-a]quinoxaline2-carboxylate (12b). White crystals (method A: 62\%); mp $161{ }^{\circ} \mathrm{C}$. IR $(\mathrm{KBr}) 3395(\mathrm{NH}), 2105(\mathrm{C} \equiv \mathrm{C}), 1685(\mathrm{COO}) .{ }^{1} \mathrm{H}$ NMR $\left(\mathrm{CDCl}_{3}\right) \delta: 8.37$ $(\mathrm{s}, 1 \mathrm{H}, \mathrm{NH}), 8.05(\mathrm{~d}, 1 \mathrm{H}, J=1.40 \mathrm{~Hz}, \mathrm{H}-1), 7.91(\mathrm{dd}, 1 \mathrm{H}, J=7.90$ and $1.50 \mathrm{~Hz}, \mathrm{H}-9), 7.79-7.76\left(\mathrm{~m}, 2 \mathrm{H}, \mathrm{H}-2^{\prime}\right.$ and $\left.\mathrm{H}-6^{\prime}\right), 7.44-7.32(\mathrm{~m}, 3 \mathrm{H}$, $\mathrm{H}-6, \mathrm{H}-7$ and $\mathrm{H}-8), 7.26-7.22\left(\mathrm{~m}, 2 \mathrm{H}, \mathrm{H}-3\right.$ and $\left.\mathrm{H}-5^{\prime}\right), 6.93-6.91$ (m, $\left.1 \mathrm{H}, \mathrm{H}-4^{\prime}\right), 4.39\left(\mathrm{q}, 2 \mathrm{H}, J=7.20 \mathrm{~Hz}, \mathrm{OCH}_{2}\right), 3.11(\mathrm{~s}, 1 \mathrm{H}, \mathrm{C} \equiv \mathrm{CH}), 1.42(\mathrm{t}$, 
$3 \mathrm{H}, J=7.20 \mathrm{~Hz}, \mathrm{CH}_{3}$ ). Anal. Calcd. for $\mathrm{C}_{22} \mathrm{H}_{17} \mathrm{~N}_{3} \mathrm{O}_{2}: \mathrm{C}, 74.35 ; \mathrm{H}, 4.82$; N, 11.82. Found: C, 74.50; H, 4.97; N, 11.76.

6.1.10.3. Ethyl 4-[(3-chlorophenyl)amino]pyrrolo[1,2-a]quinoxaline3-carboxylate (12c). Pale-yellow crystals (method A: 45\%; method B: $48 \%$ ); mp $146{ }^{\circ} \mathrm{C}$. IR ( $\left.\mathrm{KBr}\right) 3410$ (NH), 1690 (COO). ${ }^{1} \mathrm{H}$ NMR $\left(\right.$ DMSO- $\left.d_{6}\right) \delta: 12.19(\mathrm{~s}, 1 \mathrm{H}, \mathrm{NH}), 8.49(\mathrm{~d}, 1 \mathrm{H}, J=3.30 \mathrm{~Hz}, \mathrm{H}-1), 8.35(\mathrm{~d}$, $\left.1 \mathrm{H}, J=2.10 \mathrm{~Hz}, \mathrm{H}-2^{\prime}\right), 8.27(\mathrm{dd}, 1 \mathrm{H}, J=8.10$ and $1.20 \mathrm{~Hz}, \mathrm{H}-9), 7.77-$ $7.73\left(\mathrm{~m}, 1 \mathrm{H}, \mathrm{H}-6^{\prime}\right.$ ), 7.69 (dd, $1 \mathrm{H}, J=8.10$ and $1.20 \mathrm{~Hz}, \mathrm{H}-6$ ), $7.52-7.44$ $(\mathrm{m}, 2 \mathrm{H}, \mathrm{H}-7$ and $\mathrm{H}-8), 7.42\left(\mathrm{t}, 1 \mathrm{H}, J=8.10 \mathrm{~Hz}, \mathrm{H}-5^{\prime}\right), 7.33(\mathrm{~d}, 1 \mathrm{H}$, $J=3.30 \mathrm{~Hz}, \mathrm{H}-2), 7.14-7.10\left(\mathrm{~m}, 1 \mathrm{H}, \mathrm{H}-4^{\prime}\right), 4.42(\mathrm{q}, 2 \mathrm{H}, J=7.20 \mathrm{~Hz}$, $\left.\mathrm{OCH}_{2}\right), 1.39\left(\mathrm{t}, 3 \mathrm{H}, J=7.20 \mathrm{~Hz}, \mathrm{CH}_{3}\right)$. Anal. Calcd. for $\mathrm{C}_{20} \mathrm{H}_{16} \mathrm{ClN}_{3} \mathrm{O}_{2}$ : C, 65.67; H, 4.41; N, 11.49. Found: C, 65.48; H, 4.32; N, 11.53.

6.1.10.4. Ethyl 4-[(3-ethynylphenyl)amino]pyrrolo[1,2-a]quinoxaline3 -carboxylate (12d). Yellow crystals (method A: 52\%); mp $122{ }^{\circ} \mathrm{C}$. IR $(\mathrm{KBr}) 3390(\mathrm{NH}), 2100(\mathrm{C} \equiv \mathrm{C}), 1695(\mathrm{COO}) .{ }^{1} \mathrm{H}$ NMR (DMSO-d $\left.d_{6}\right) \delta$ : $12.07(\mathrm{~s}, 1 \mathrm{H}, \mathrm{NH}), 8.44(\mathrm{~d}, 1 \mathrm{H}, J=3.10 \mathrm{~Hz}, \mathrm{H}-1), 8.25-8.17(\mathrm{~m}, 2 \mathrm{H}, \mathrm{H}-$ $2^{\prime}$ and $\left.\mathrm{H}-9\right), 8.03-8.00\left(\mathrm{~m}, 1 \mathrm{H}, \mathrm{H}-6^{\prime}\right), 7.70-7.66(\mathrm{~m}, 1 \mathrm{H}, \mathrm{H}-6), 7.51-$ $7.40\left(\mathrm{~m}, 3 \mathrm{H}, \mathrm{H}-5^{\prime}, \mathrm{H}-7\right.$ and $\left.\mathrm{H}-8\right), 7.31(\mathrm{~d}, 1 \mathrm{H}, J=3.10 \mathrm{~Hz}, \mathrm{H}-2), 7.18$ $7.16\left(\mathrm{~m}, 1 \mathrm{H}, \mathrm{H}-4^{\prime}\right), 4.47\left(\mathrm{q}, 2 \mathrm{H}, J=6.90 \mathrm{~Hz}, \mathrm{OCH}_{2}\right), 4.17(\mathrm{~s}, 1 \mathrm{H}, \mathrm{C} \equiv \mathrm{CH})$, $1.40\left(\mathrm{t}, 3 \mathrm{H}, J=6.90 \mathrm{~Hz}, \mathrm{CH}_{3}\right)$. Anal. Calcd. for $\mathrm{C}_{22} \mathrm{H}_{17} \mathrm{~N}_{3} \mathrm{O}_{2}$ : C, 74.35; H, 4.82; N, 11.82. Found: C, 74.17; H, 4.65; N, 11.91 .

6.1.10.5. Ethyl 4-[(3-chlorophenyl)amino]pyrrolo[1,2-a]quinoxaline7-carboxylate $(\mathbf{1 2 e})$. White crystals (method A: 74\%; method B: $69 \%$ ); mp $236{ }^{\circ} \mathrm{C}$. IR (KBr) 3375 (NH), 1685 (COO). ${ }^{1} \mathrm{H}$ NMR (DMSO$\left.d_{6}\right) \delta: 9.41(\mathrm{~s}, 1 \mathrm{H}, \mathrm{NH}), 8.41(\mathrm{dd}, 1 \mathrm{H}, J=3.00$ and $1.20 \mathrm{~Hz}, \mathrm{H}-1), 8.27$ (d, $1 \mathrm{H}, J=1.50 \mathrm{~Hz}, \mathrm{H}-6), 8.23$ (d, $1 \mathrm{H}, J=8.20 \mathrm{~Hz}, \mathrm{H}-9), 8.13$ (d, $1 \mathrm{H}$, $\left.J=1.80 \mathrm{~Hz}, \mathrm{H}-2^{\prime}\right), 8.05(\mathrm{dd}, 1 \mathrm{H}, J=8.20$ and $1.50 \mathrm{~Hz}, \mathrm{H}-8), 7.87$ (dd, $1 \mathrm{H}, J=8.20$ and $\left.1.60 \mathrm{~Hz}, \mathrm{H}-6^{\prime}\right), 7.45(\mathrm{dd}, 1 \mathrm{H}, J=3.60$ and $1.20 \mathrm{~Hz}, \mathrm{H}-$ 3), $7.41\left(\mathrm{t}, 1 \mathrm{H}, J=8.20 \mathrm{~Hz}, \mathrm{H}-5^{\prime}\right), 7.10(\mathrm{dd}, 1 \mathrm{H}, J=8.20$ and $1.80 \mathrm{~Hz}, \mathrm{H}-$ $\left.4^{\prime}\right), 6.92(\mathrm{dd}, 1 \mathrm{H}, J=3.60$ and $3.00 \mathrm{~Hz}, \mathrm{H}-2), 4.37(\mathrm{q}, 2 \mathrm{H}, J=7.20 \mathrm{~Hz}$, $\left.\mathrm{OCH}_{2}\right), 1.37\left(\mathrm{t}, 3 \mathrm{H}, J=7.20 \mathrm{~Hz}, \mathrm{CH}_{3}\right)$. Anal. Calcd. for $\mathrm{C}_{20} \mathrm{H}_{16} \mathrm{ClN}_{3} \mathrm{O}_{2}: \mathrm{C}$, $65.67 ; \mathrm{H}, 4.41$; N, 11.49. Found: C, 65.60; H, 4.54; N, 11.82 .

6.1.10.6. Ethyl 4-[(3-ethynylphenyl)amino]pyrrolo[1,2-a]quinoxaline7-carboxylate (12f). White crystals (method A: 78\%); mp $183^{\circ} \mathrm{C}$. IR $(\mathrm{KBr}) 3380(\mathrm{NH}), 2105(\mathrm{C} \equiv \mathrm{C}), 1695(\mathrm{COO}) .{ }^{1} \mathrm{H}$ NMR (DMSO-d $\left.d_{6}\right) \delta$ : $9.38(\mathrm{~s}, 1 \mathrm{H}, \mathrm{NH}), 8.43(\mathrm{dd}, 1 \mathrm{H}, J=3.00$ and $1.20 \mathrm{~Hz}, \mathrm{H}-1), 8.25(\mathrm{~d}, 1 \mathrm{H}$, $J=8.70 \mathrm{~Hz}, \mathrm{H}-9), 8.21-8.18(\mathrm{~m}, 2 \mathrm{H}, \mathrm{H}-6$ and $\mathrm{H}-8), 8.13(\mathrm{~d}, 1 \mathrm{H}$, $\left.J=1.80 \mathrm{~Hz}, \mathrm{H}-2^{\prime}\right), 7.87\left(\mathrm{dd}, 1 \mathrm{H}, J=8.40\right.$ and $\left.1.80 \mathrm{~Hz}, \mathrm{H}-6^{\prime}\right), 7.47(\mathrm{dd}$, $1 \mathrm{H}, J=3.90$ and $1.20 \mathrm{~Hz}, \mathrm{H}-3), 7.42\left(\mathrm{t}, 1 \mathrm{H}, J=8.400 \mathrm{~Hz}, \mathrm{H}-5^{\prime}\right), 7.17$ (dd, $1 \mathrm{H}, J=8.40$ and $\left.1.80 \mathrm{~Hz}, \mathrm{H}-4^{\prime}\right), 6.92(\mathrm{dd}, 1 \mathrm{H}, J=3.90$ and $3.00 \mathrm{~Hz}, \mathrm{H}-2), 4.37$ (q, $\left.2 \mathrm{H}, J=7.20 \mathrm{~Hz}, \mathrm{OCH}_{2}\right), 4.02(\mathrm{~s}, 1 \mathrm{H}, \mathrm{C} \equiv \mathrm{CH})$, $1.37\left(\mathrm{t}, 3 \mathrm{H}, J=7.20 \mathrm{~Hz}, \mathrm{CH}_{3}\right)$. Anal. Calcd. for $\mathrm{C}_{22} \mathrm{H}_{17} \mathrm{~N}_{3} \mathrm{O}_{2}$ : C, 74.35; $\mathrm{H}, 4.82 ; \mathrm{N}, 11.82$. Found: $\mathrm{C}, 74.21 ; \mathrm{H}, 4.99 ; \mathrm{N}, 12.10$.

6.1.10.7. Ethyl 4-[(3-chlorophenyl)amino]pyrrolo[1,2-a]quinoxaline8-carboxylate (12g). Beige crystals (method A: 69\%; method B: 76\%); mp $191{ }^{\circ} \mathrm{C}$. IR (KBr) $3400(\mathrm{NH}), 1685$ (COO). ${ }^{1} \mathrm{H}$ NMR (DMSO$\left.d_{6}\right) \delta: 9.53(\mathrm{~s}, 1 \mathrm{H}, \mathrm{NH}), 8.63(\mathrm{~d}, 1 \mathrm{H}, J=1.80 \mathrm{~Hz}, \mathrm{H}-9), 8.53(\mathrm{dd}, 1 \mathrm{H}$, $J=3.00$ and $1.20 \mathrm{~Hz}, \mathrm{H}-1), 8.32\left(\mathrm{t}, 1 \mathrm{H}, J=1.90 \mathrm{~Hz}, \mathrm{H}-2^{\prime}\right), 8.04-8.01$ ( $\mathrm{m}, 1 \mathrm{H}, \mathrm{H}-7), 7.91$ (dd, $1 \mathrm{H}, J=8.20$ and $\left.1.60 \mathrm{~Hz}, \mathrm{H}-6^{\prime}\right), 7.66(\mathrm{~d}, 1 \mathrm{H}$, $J=8.40 \mathrm{~Hz}, \mathrm{H}-6), 7.48(\mathrm{dd}, 1 \mathrm{H}, J=3.90$ and $1.20 \mathrm{~Hz}, \mathrm{H}-3), 7.41(\mathrm{t}, 1 \mathrm{H}$, $\left.J=8.20 \mathrm{~Hz}, \mathrm{H}-5^{\prime}\right), 7.13-7.10\left(\mathrm{~m}, 1 \mathrm{H}, \mathrm{H}-4^{\prime}\right), 6.88(\mathrm{dd}, 1 \mathrm{H}, J=3.90$ and $3.00 \mathrm{~Hz}, \mathrm{H}-2), 4.37$ (q, $\left.2 \mathrm{H}, J=7.10 \mathrm{~Hz}, \mathrm{OCH}_{2}\right), 1.38(\mathrm{t}, 3 \mathrm{H}, J=7.10 \mathrm{~Hz}$, $\mathrm{CH}_{3}$ ). Anal. Calcd. for $\mathrm{C}_{20} \mathrm{H}_{16} \mathrm{ClN}_{3} \mathrm{O}_{2}$ : C, 65.67; $\mathrm{H}, 4.41 ; \mathrm{N}, 11.49$. Found: C, 65.42; $\mathrm{H}, 4.29 ; \mathrm{N}, 11.53$.

6.1.10.8. Ethyl 4-[(3-ethynylphenyl)aminolpyrrolo[1,2-a]quinoxaline8 -carboxylate $(\mathbf{1 2 h})$. Beige crystals (method A: 70\%); mp $206{ }^{\circ} \mathrm{C}$. IR $(\mathrm{KBr}) 3385(\mathrm{NH}), 2100(\mathrm{C} \equiv \mathrm{C}), 1685(\mathrm{COO}) .{ }^{1} \mathrm{H}$ NMR $\left(\mathrm{DMSO}-d_{6}\right) \delta$ : $9.48(\mathrm{~s}, 1 \mathrm{H}, \mathrm{NH}), 8.63-8.61(\mathrm{~m}, 1 \mathrm{H}, \mathrm{H}-9), 8.53-8.52(\mathrm{~m}, 1 \mathrm{H}, \mathrm{H}-1)$, 8.24-8.23 (m, 1H, H-2'), 8.19-8.13 (m, 1H, H-7), 7.92-7.89 (m, $1 \mathrm{H}$,
H-6') $7.66-7.62(\mathrm{~m}, 1 \mathrm{H}, \mathrm{H}-6), 7.46-7.38\left(\mathrm{~m}, 2 \mathrm{H}, \mathrm{H}-3\right.$ and $\left.\mathrm{H}-5^{\prime}\right)$, $7.20-7.17\left(\mathrm{~m}, 1 \mathrm{H}, \mathrm{H}-4^{\prime}\right), 6.88-6.86(\mathrm{~m}, 1 \mathrm{H}, \mathrm{H}-2), 4.36(\mathrm{q}, 2 \mathrm{H}$, $\left.J=7.10 \mathrm{~Hz}, \mathrm{OCH}_{2}\right), 4.23(\mathrm{~s}, 1 \mathrm{H}, \mathrm{C} \equiv \mathrm{CH}), 1.37\left(\mathrm{t}, 3 \mathrm{H}, J=7.10 \mathrm{~Hz}, \mathrm{CH}_{3}\right)$. Anal. Calcd. for $\mathrm{C}_{22} \mathrm{H}_{17} \mathrm{~N}_{3} \mathrm{O}_{2}$ : C, 74.35; $\mathrm{H}, 4.82 ; \mathrm{N}, 11.82$. Found: $\mathrm{C}$, 74.46; H, 4.87; N, 12.06 .

6.1.10.9. Ethyl 4-[(3-chlorophenyl)aminolpyrrolo[1,2-a]quinoxaline9-carboxylate (12i). Beige crystals (method A: 75\%; method B: $65 \%) ; \mathrm{mp} 172{ }^{\circ} \mathrm{C}$. IR (KBr) $3390(\mathrm{NH}), 1690$ (COO). ${ }^{1} \mathrm{H}$ NMR (DMSO$\left.d_{6}\right) \delta: 9.43(\mathrm{~s}, 1 \mathrm{H}, \mathrm{NH}), 8.31\left(\mathrm{t}, 1 \mathrm{H}, J=1.60 \mathrm{~Hz}, \mathrm{H}-2^{\prime}\right), 8.01(\mathrm{dd}, 1 \mathrm{H}$, $J=7.80$ and $\left.1.60 \mathrm{~Hz}, \mathrm{H}-6^{\prime}\right), 7.79-7.76(\mathrm{~m}, 1 \mathrm{H}, \mathrm{H}-6), 7.66(\mathrm{dd}, 1 \mathrm{H}$, $J=3.00$ and $1.20, \mathrm{H}-1), 7.48(\mathrm{dd}, 1 \mathrm{H}, J=3.90$ and $1.20 \mathrm{~Hz}, \mathrm{H}-3$ ), 7.45-7.43 ( $\mathrm{m}, 2 \mathrm{H}, \mathrm{H}-7$ and $\mathrm{H}-8), 7.40\left(\mathrm{t}, 1 \mathrm{H}, J=7.80 \mathrm{~Hz}, \mathrm{H}-5^{\prime}\right), 7.09$ $\left(\mathrm{dd}, 1 \mathrm{H}, J=7.80\right.$ and $\left.1.60 \mathrm{~Hz}, \mathrm{H}-4^{\prime}\right), 6.88(\mathrm{dd}, 1 \mathrm{H}, J=3.90$ and $3.00 \mathrm{~Hz}, \mathrm{H}-2), 4.48$ (q, $\left.2 \mathrm{H}, J=7.20 \mathrm{~Hz}, \mathrm{OCH}_{2}\right), 1.35(\mathrm{t}, 3 \mathrm{H}, J=7.20 \mathrm{~Hz}$, $\mathrm{CH}_{3}$ ). Anal. Calcd. for $\mathrm{C}_{20} \mathrm{H}_{16} \mathrm{ClN}_{3} \mathrm{O}_{2}$ : C, 65.67; $\mathrm{H}, 4.41 ; \mathrm{N}, 11.49$. Found: C, 65.86; H, 4.39; N, 11.64.

6.1.10.10. Ethyl 4-[(3-ethynylphenyl)amino]pyrrolo[1,2-a]quinoxaline-9-carboxylate (12j). Beige crystals (method A: 79\%); $\mathrm{mp} 141^{\circ} \mathrm{C}$. IR ( KBr) $3390(\mathrm{NH}), 2105(\mathrm{C} \equiv \mathrm{C}), 1685(\mathrm{COO}) .{ }^{1} \mathrm{H}$ NMR (DMSO-d 6 ) $\delta$ : $9.34(\mathrm{~s}, 1 \mathrm{H}, \mathrm{NH}), 8.21\left(\mathrm{t}, 1 \mathrm{H}, J=1.70 \mathrm{~Hz}, \mathrm{H}-2^{\prime}\right), 8.15(\mathrm{~d}, 1 \mathrm{H}$, $\left.J=8.00 \mathrm{~Hz}, \mathrm{H}-6^{\prime}\right), 7.77-7.73(\mathrm{~m}, 1 \mathrm{H}, \mathrm{H}-6), 7.65(\mathrm{dd}, 1 \mathrm{H}, J=3.00$ and $1.20, \mathrm{H}-1), 7.48(\mathrm{dd}, 1 \mathrm{H}, J=3.90$ and $1.20 \mathrm{~Hz}, \mathrm{H}-3), 7.44-7.40(\mathrm{~m}, 2 \mathrm{H}$, $\mathrm{H}-7$ and $\mathrm{H}-8), 7.39\left(\mathrm{t}, 1 \mathrm{H}, J=8.00 \mathrm{~Hz}, \mathrm{H}-5^{\prime}\right), 7.16(\mathrm{~d}, 1 \mathrm{H}, J=8.00 \mathrm{~Hz}$, $\left.\mathrm{H}-4^{\prime}\right), 6.87(\mathrm{dd}, 1 \mathrm{H}, J=3.90$ and $3.00 \mathrm{~Hz}, \mathrm{H}-2), 4.98(\mathrm{q}, 2 \mathrm{H}$, $\left.J=7.20 \mathrm{~Hz}, \mathrm{OCH}_{2}\right), 4.19(\mathrm{~s}, 1 \mathrm{H}, \mathrm{C} \equiv \mathrm{CH}), 1.35\left(\mathrm{t}, 3 \mathrm{H}, J=7.20 \mathrm{~Hz}, \mathrm{CH}_{3}\right)$. Anal. Calcd. for $\mathrm{C}_{22} \mathrm{H}_{17} \mathrm{~N}_{3} \mathrm{O}_{2}$ : C, 74.35; $\mathrm{H}, 4.82 ; \mathrm{N}, 11.82$. Found: $\mathrm{C}$, 74.54; H, 4.98; N, 12.14 .

6.1.10.11. Ethyl 7-[(3-chlorophenyl)amino]pyrrolo[1,2-a]quinoxaline4-carboxylate (12k). Orange crystals (method B: $37 \%$ ); mp $115^{\circ} \mathrm{C}$. IR $(\mathrm{KBr}) 3425(\mathrm{NH}), 1725(\mathrm{COO}) .{ }^{1} \mathrm{H}$ NMR $\left(\mathrm{CDCl}_{3}\right) \delta: 7.98-7.97(\mathrm{~m}, 1 \mathrm{H}$, $\mathrm{H}-1$ ), 7.85 (d, 1H, $J=1.40 \mathrm{~Hz}, \mathrm{H}-6), 7.83$ (d, $1 \mathrm{H}, J=8.20 \mathrm{~Hz}, \mathrm{H}-9$ ), 7.53-7.52 (m, $1 \mathrm{H}, \mathrm{H}-3), 7.36(\mathrm{dd}, 1 \mathrm{H}, J=8.20$ and $1.40 \mathrm{~Hz}, \mathrm{H}-8), 7.21$ $\left(\mathrm{t}, 1 \mathrm{H}, J=8.10 \mathrm{~Hz}, \mathrm{H}-5^{\prime}\right), 7.11\left(\mathrm{t}, 1 \mathrm{H}, J=1.70 \mathrm{~Hz}, \mathrm{H}-2^{\prime}\right), 7.03-6.93(\mathrm{~m}$, $3 \mathrm{H}, \mathrm{H}-4^{\prime}, \mathrm{H}-6^{\prime}$ and $\left.\mathrm{H}-2\right), 5.98(\mathrm{~s}, 1 \mathrm{H}, \mathrm{NH}), 4.60(\mathrm{q}, 2 \mathrm{H}, J=7.20 \mathrm{~Hz}$, $\left.\mathrm{OCH}_{2}\right), 1.53\left(\mathrm{t}, 3 \mathrm{H}, J=7.20 \mathrm{~Hz}, \mathrm{CH}_{3}\right)$. Anal. Calcd. for $\mathrm{C}_{20} \mathrm{H}_{16} \mathrm{ClN}_{3} \mathrm{O}_{2}$ : C, 65.67; H, 4.41; N, 11.49. Found: C, 65.54; H, 4.65; N, 11.57 .

6.1.10.12. Ethyl 7-\{[3-(2-trimethylsilylethynyl)phenyl]amino\}pyrrolo [1,2-a]quinoxaline-4-carboxylate (12l). Orange crystals (method B: $12 \%) ; \mathrm{mp} 59^{\circ} \mathrm{C}$. IR $(\mathrm{KBr}) 3410(\mathrm{NH}), 2100(\mathrm{C} \equiv \mathrm{C}), 1720$ (COO). ${ }^{1} \mathrm{H}$ NMR $\left(\mathrm{CDCl}_{3}\right) \delta: 8.01(\mathrm{dd}, 1 \mathrm{H}, J=2.70$ and $1.20 \mathrm{~Hz}, \mathrm{H}-1), 7.89-7.85(\mathrm{~m}, 2 \mathrm{H}$, H-6 and H-9), 7.57 (dd, $1 \mathrm{H}, J=3.90$ and $1.20 \mathrm{~Hz}, \mathrm{H}-3$ ), 7.29 (dd, $1 \mathrm{H}$, $J=8.30$ and $2.40 \mathrm{~Hz}, \mathrm{H}-8), 7.22\left(\mathrm{t}, 1 \mathrm{H}, J=1.70 \mathrm{~Hz}, \mathrm{H}-2^{\prime}\right), 7.17(\mathrm{t}, 1 \mathrm{H}$, $\left.J=7.80 \mathrm{~Hz}, \mathrm{H}-5^{\prime}\right), 7.10-7.04\left(\mathrm{~m}, 2 \mathrm{H}, \mathrm{H}-4^{\prime}\right.$ and $\left.\mathrm{H}-6^{\prime}\right), 6.94(\mathrm{dd}, 1 \mathrm{H}$, $J=3.90$ and $2.70 \mathrm{~Hz}, \mathrm{H}-2), 6.11(\mathrm{~s}, 1 \mathrm{H}, \mathrm{NH}), 4.58(\mathrm{q}, 2 \mathrm{H}, J=7.10 \mathrm{~Hz}$, $\left.\mathrm{OCH}_{2}\right), 1.48\left(\mathrm{t}, 3 \mathrm{H}, J=7.10 \mathrm{~Hz}, \mathrm{CH}_{3}\right)$. Anal. Calcd. for $\mathrm{C}_{25} \mathrm{H}_{25} \mathrm{~N}_{3} \mathrm{O}_{2} \mathrm{Si}: \mathrm{C}$, 70.23; H, 5.89; N, 9.83. Found: C, 70.39; H, 6.02; N, 10.05.

6.1.10.13. Ethyl 4-[(3-chlorophenyl)amino]-2-(3-pyridyl)pyrrolo[1,2a]quinoxaline-7-carboxylate $(\mathbf{1 2 m})$. Beige crystals (method A: $61 \%$; method B: 67\%); mp $234{ }^{\circ} \mathrm{C}$. IR ( $\left.\mathrm{KBr}\right) 3380(\mathrm{NH}), 1710(\mathrm{COO}) .{ }^{1} \mathrm{H}$ NMR (DMSO- $\left.d_{6}\right) \delta: 9.44(\mathrm{~s}, 1 \mathrm{H}, \mathrm{NH}), 9.03-8.99(\mathrm{~m}, 2 \mathrm{H}, \mathrm{H}-1$ and $\mathrm{H}-$ 6), 8.52-8.50 ( $\left.\mathrm{m}, 1 \mathrm{H}, \mathrm{H}-4^{\prime}\right), 8.27-8.17\left(\mathrm{~m}, 2 \mathrm{H}, \mathrm{H}-6^{\prime}\right.$ and $\left.\mathrm{H}-9\right), 8.10-$ $8.03\left(\mathrm{~m}, 3 \mathrm{H}, \mathrm{H}-2^{\prime \prime}, \mathrm{H}-2^{\prime}\right.$ and $\left.\mathrm{H}-8\right), 7.90-7.84\left(\mathrm{~m}, 2 \mathrm{H}, \mathrm{H}-3\right.$ and $\left.\mathrm{H}-6^{\prime \prime}\right)$, 7.52-7.50 (m, $\left.1 \mathrm{H}, \mathrm{H}-5^{\prime}\right), 7.45-7.39\left(\mathrm{~m}, 1 \mathrm{H}, \mathrm{H}-5^{\prime \prime}\right), 7.10-7.08(\mathrm{~m}, 1 \mathrm{H}$, $\left.\mathrm{H}-4^{\prime \prime}\right), 4.35\left(\mathrm{q}, 2 \mathrm{H}, J=7.20 \mathrm{~Hz}, \mathrm{OCH}_{2}\right), 1.37\left(\mathrm{t}, 3 \mathrm{H}, J=7.20 \mathrm{~Hz}, \mathrm{CH}_{3}\right)$. Anal. Calcd. for $\mathrm{C}_{25} \mathrm{H}_{19} \mathrm{ClN}_{4} \mathrm{O}_{2}$ : C, 67.80; H, 4.32; N, 12.65. Found: C, $67.96 ; \mathrm{H}, 4.44 ; \mathrm{N}, 12.80$.

6.1.10.14. Ethyl 4-[(3-ethynylphenyl)amino]-2-(3-pyridyl)pyrrolo [1,2-a]quinoxaline-7-carboxylate (12n). Beige crystals (method A: 53\%); mp $192{ }^{\circ} \mathrm{C}$. IR (KBr) $3285(\mathrm{NH}), 2100(\mathrm{C} \equiv \mathrm{C}), 1700(\mathrm{COO}) .{ }^{1} \mathrm{H}$ 
NMR (DMSO- $\left.d_{6}\right) \delta$ : $9.42(\mathrm{~s}, 1 \mathrm{H}, \mathrm{NH}), 9.05-9.04(\mathrm{~m}, 2 \mathrm{H}, \mathrm{H}-1$ and $\mathrm{H}-$ 6), 8.53-8.51 (m, 1H, H-4'), 8.26-8.11 (m, 5H, H-8, H-9, H-2', H-6 and $\left.\mathrm{H}-2^{\prime \prime}\right), 7.95-7.88\left(\mathrm{~m}, 2 \mathrm{H}, \mathrm{H}-3\right.$ and $\left.\mathrm{H}-6^{\prime \prime}\right), 7.54-7.50(\mathrm{~m}, 1 \mathrm{H}, \mathrm{H}-$ $\left.5^{\prime}\right), 7.46-7.41\left(\mathrm{~m}, 1 \mathrm{H}, \mathrm{H}-5^{\prime \prime}\right), 7.20-7.17\left(\mathrm{~m}, 1 \mathrm{H}, \mathrm{H}-4^{\prime \prime}\right), 4.38(\mathrm{q}, 2 \mathrm{H}$, $\left.J=6.90 \mathrm{~Hz}, \mathrm{OCH}_{2}\right), 4.23(\mathrm{~s}, 1 \mathrm{H}, \mathrm{C} \equiv \mathrm{CH}), 1.37\left(\mathrm{t}, 3 \mathrm{H}, J=6.90 \mathrm{~Hz}, \mathrm{CH}_{3}\right)$. Anal. Calcd. for $\mathrm{C}_{27} \mathrm{H}_{20} \mathrm{~N}_{4} \mathrm{O}_{2}$ : C, 74.99; $\mathrm{H}, 4.66 ; \mathrm{N}, 12.95$. Found: $\mathrm{C}$, 75.13; H, 4.78; N, 12.81 .

6.1.11. General procedure for 4-[(3-substituted-phenyl)amino] pyrrolo[1,2-a]quinoxaline-carboxylic acids $(\mathbf{1 a}-\mathbf{j})$ and ethyl 7-[(3substituted-phenyl)amino]pyrrolo[1,2-a]quinoxaline-4-carboxylic acids $\mathbf{1 k}, \mathbf{l}$ and ethyl 4-[(3-substituted-phenyl)amino]-2-(3-pyridyl) pyrrolo[1,2-a]quinoxaline-7-carboxylic acids $\mathbf{1 m , n}$

A mixture of ethyl 4-[(3-substituted-phenyl)amino]pyrrolo[1,2-a] quinoxaline-carboxylates 12a-j or ethyl 7-[(3-substituted-phenyl) amino]pyrrolo[1,2-a]quinoxaline-4-carboxylates 12k,l or ethyl 4-[(3substituted-phenyl)amino]-2-(3-pyridyl)pyrrolo[1,2-a]quinoxaline7-carboxylates $\mathbf{1 2 m}, \mathbf{n}(0.6 \mathrm{mmol})$ in methanol $(15 \mathrm{~mL})$ and a $\mathrm{NaOH}$ aqueous solution ( $4.8 \mathrm{mmol}$ in $8 \mathrm{~mL}$ ) was refluxed for $4 \mathrm{~h}$. On cooling, after removal of the solvent under reduced pressure, the residue was diluted with water and adjusted to $\mathrm{pH}=6$ with $1 \mathrm{M} \mathrm{HCl}$ aqueous solution. The solid precipitate was filtered off and washed with water then with diethyl ether, and purified by column chromatography using $\mathrm{CH}_{2} \mathrm{Cl}_{2} /$ methanol $(9 / 1, \mathrm{v} / \mathrm{v})$ as eluent to give $\mathbf{1 a}-\mathbf{n}$.

6.1.11.1. 4-[(3-Chlorophenyl)amino]pyrrolo[1,2-a]quinoxaline-2carboxylic acid (1a). Pale-yellow crystals (91\%); $\mathrm{mp}>300{ }^{\circ} \mathrm{C}$. IR (KBr) $3290(\mathrm{NH}), 3100-2650(\mathrm{COOH}), 1685$ (COO). ${ }^{1} \mathrm{H}$ NMR (DMSO$\left.d_{6}\right) \delta: 12.10(\mathrm{bs}, 1 \mathrm{H}, \mathrm{COOH}), 9.43(\mathrm{~s}, 1 \mathrm{H}, \mathrm{NH}), 8.44-8.43(\mathrm{~m}, 2 \mathrm{H}, \mathrm{H}-1$ and $\left.\mathrm{H}-2^{\prime}\right), 8.16-8.10\left(\mathrm{~m}, 2 \mathrm{H}, \mathrm{H}-9\right.$ and $\left.\mathrm{H}-\mathrm{G}^{\prime}\right), 7.73(\mathrm{~d}, 1 \mathrm{H}, J=1.50 \mathrm{~Hz}$, $\mathrm{H}-3$ ), 7.59 (dd, $1 \mathrm{H}, J=7.90$ and $1.35 \mathrm{~Hz}, \mathrm{H}-6), 7.39-7.30$ ( $\mathrm{m}, 3 \mathrm{H}, \mathrm{H}-7$, $\mathrm{H}-8$ and $\mathrm{H}-5^{\prime}$ ), 7.03 (dd, $1 \mathrm{H}, J=8.10$ and $\left.1.50 \mathrm{~Hz}, \mathrm{H}-4^{\prime}\right) .{ }^{13} \mathrm{C}$ NMR (DMSO- $d_{6}$ ) $\delta$ : 168.1, 146.6, 142.0, 135.0, 132.2, 129.7, 129.5, 126.2, 125.0, 124.7, 123.6, 120.6, 118.6, 117.7, 117.5, 117.0, 113.8, 106.6. Anal. Calcd. for $\mathrm{C}_{18} \mathrm{H}_{12} \mathrm{ClN}_{3} \mathrm{O}_{2}$ : C, 64.01; $\mathrm{H}, 3.58 ; \mathrm{N}, 12.44$. Found: C, 63.85; $\mathrm{H}, 3.43 ; \mathrm{N}, 12.77$.

6.1.11.2. 4-[(3-Ethynylphenyl)amino]pyrrolo[1,2-a]quinoxaline-2carboxylic acid (1b). Beige crystals (90\%); $\mathrm{mp}>300{ }^{\circ} \mathrm{C}$. IR $(\mathrm{KBr})$ $3285(\mathrm{NH}), 3150-2600(\mathrm{COOH}), 2105(\mathrm{C} \equiv \mathrm{C}), 1685$ (COO). ${ }^{1} \mathrm{H}$ NMR (DMSO-d $)_{6} \delta: 9.43(\mathrm{~s}, 1 \mathrm{H}, \mathrm{NH}), 8.58(\mathrm{~d}, 1 \mathrm{H}, J=1.35 \mathrm{~Hz}, \mathrm{H}-1), 8.35$ (d, $\left.1 \mathrm{H}, J=1.70 \mathrm{~Hz}, \mathrm{H}-2^{\prime}\right), 8.23(\mathrm{~d}, 1 \mathrm{H}, J=7.80 \mathrm{~Hz}, \mathrm{H}-9), 8.16(\mathrm{~d}, 1 \mathrm{H}$, $\left.J=7.80 \mathrm{~Hz}, \mathrm{H}-6^{\prime}\right), 7.84(\mathrm{~d}, 1 \mathrm{H}, J=1.35 \mathrm{~Hz}, \mathrm{H}-3), 7.58(\mathrm{~d}, 1 \mathrm{H}$, $J=7.80 \mathrm{~Hz}, \mathrm{H}-6), 7.40-7.28$ ( $\mathrm{m}, 3 \mathrm{H}, \mathrm{H}-7, \mathrm{H}-8$ and $\left.\mathrm{H}-5^{\prime}\right), 7.12(\mathrm{~d}, 1 \mathrm{H}$, $\left.J=7.80 \mathrm{~Hz}, \mathrm{H}-4^{\prime}\right), 5.80$ (bs, $\left.1 \mathrm{H}, \mathrm{COOH}\right), 4.19(\mathrm{~s}, 1 \mathrm{H}, \mathrm{C} \equiv \mathrm{CH}) .{ }^{13} \mathrm{C} \mathrm{NMR}$ (DMSO- $d_{6}$ ) $\delta: 172.9,167.4,146.5,140.5,135.3,128.3,126.3,125.6$, 125.1, 124.7, 123.5, 122.4, 121.2, 120.2, 118.1, 117.9, 113.9, 106.5, 83.4, 79.6. Anal. Calcd. for $\mathrm{C}_{20} \mathrm{H}_{13} \mathrm{~N}_{3} \mathrm{O}_{2}$ : C, 73.38; $\mathrm{H}, 4.00 ; \mathrm{N}, 12.84$. Found: C, $73.18 ; \mathrm{H}, 3.86 ; \mathrm{N}, 12.70$.

6.1.11.3. 4-[(3-Chlorophenyl)amino]pyrrolo[1,2-a]quinoxaline-3carboxylic acid (1c). Pale-yellow crystals (84\%); mp $229^{\circ} \mathrm{C}$. IR $(\mathrm{KBr})$ $3300(\mathrm{NH}), 3100-2600(\mathrm{COOH}), 1685$ (COO). ${ }^{1} \mathrm{H}$ NMR (DMSO-d 6 ) $\delta$ : $13.60(\mathrm{~s}, 1 \mathrm{H}, \mathrm{NH}), 8.40(\mathrm{~d}, 1 \mathrm{H}, J=3.00 \mathrm{~Hz}, \mathrm{H}-1), 8.39(\mathrm{t}, 1 \mathrm{H}$, $\left.J=2.10 \mathrm{~Hz}, \mathrm{H}-2^{\prime}\right), 8.24(\mathrm{dd}, 1 \mathrm{H}, J=7.90$ and $1.50 \mathrm{~Hz}, \mathrm{H}-9), 7.78$ (dd, $1 \mathrm{H}, J=8.10$ and $\left.1.10 \mathrm{~Hz}, \mathrm{H}-6^{\prime}\right), 7.66(1 \mathrm{H}, J=7.90$ and $1.50 \mathrm{~Hz}, \mathrm{H}-6)$, 7.47-7.37 ( $\mathrm{m}, 2 \mathrm{H}, \mathrm{H}-7$ and $\mathrm{H}-8), 7.39\left(\mathrm{t}, 1 \mathrm{H}, J=8.10 \mathrm{~Hz}, \mathrm{H}-5^{\prime}\right)$, $7.27(\mathrm{~d}, 1 \mathrm{H}, J=3.00 \mathrm{~Hz}, \mathrm{H}-2), 7.09-7.06\left(\mathrm{~m}, 1 \mathrm{H}, \mathrm{H}-4^{\prime}\right) .{ }^{13} \mathrm{C} \mathrm{NMR}$ (DMSO-d ( $_{6} \delta$ : 167.9, 145.6, 141.6, 135.2, 132.7, 129.9, 129.8, 126.0, 125.9, 123.9, 123.7, 120.9, 119.3, 118.0, 117.0, 116.4, 115.3, 114.4. Anal. Calcd. for $\mathrm{C}_{18} \mathrm{H}_{12} \mathrm{ClN}_{3} \mathrm{O}_{2}$ : C, 64.01; $\mathrm{H}, 3.58 ; \mathrm{N}, 12.44$. Found: C, 63.94; $\mathrm{H}, 3.63 ; \mathrm{N}, 12.67$.

6.1.11.4. 4-[(3-Ethynylphenyl)amino]pyrrolo[1,2-a]quinoxaline-3carboxylic acid $(\mathbf{1 d})$. Yellow crystals $(81 \%) ; \mathrm{mp} 210^{\circ} \mathrm{C}$. IR (KBr) 3280
(NH), 3100-2650 (COOH), 2100 (C $\equiv \mathrm{C}), 1685$ (COO). ${ }^{1} \mathrm{H}$ NMR (DMSO-d $) \delta: 13.73(\mathrm{~s}, 1 \mathrm{H}, \mathrm{NH}), 8.34(\mathrm{~d}, 1 \mathrm{H}, J=3.00 \mathrm{~Hz}, \mathrm{H}-1), 8.23(\mathrm{t}$, $\left.1 \mathrm{H}, J=1.90 \mathrm{~Hz}, \mathrm{H}-2^{\prime}\right), 8.18$ (dd, $1 \mathrm{H}, J=7.80$ and $\left.1.50 \mathrm{~Hz}, \mathrm{H}-9\right), 8.03$ $\left(\mathrm{dd}, 1 \mathrm{H}, J=8.10\right.$ and $\left.1.10 \mathrm{~Hz}, \mathrm{H}-6^{\prime}\right), 7.64(\mathrm{dd}, 1 \mathrm{H}, J=7.80$ and $1.50 \mathrm{~Hz}$, H-6), 7.43-7.35 (m, 3H, H-7, H-8 and H-5'), $7.26(\mathrm{~d}, 1 \mathrm{H}, J=3.00 \mathrm{~Hz}$, $\mathrm{H}-2), 7.14-7.11\left(\mathrm{~m}, 1 \mathrm{H}, \mathrm{H}-4^{\prime}\right), 4.14(\mathrm{~s}, 1 \mathrm{H}, \mathrm{C} \equiv \mathrm{CH}) .{ }^{13} \mathrm{C}$ NMR (DMSO$\left.d_{6}\right) \delta: 167.9,145.8,140.5,135.4,128.8,128.7,125.9,125.8,124.5$, 123.8, 123.5, 121.6, 121.4, 119.2, 119.1, 116.4, 115.0, 114.3, 83.3, 79.8 . Anal. Calcd. for $\mathrm{C}_{20} \mathrm{H}_{13} \mathrm{~N}_{3} \mathrm{O}_{2}$ : C, 73.38; $\mathrm{H}, 4.00 ; \mathrm{N}, 12.84$. Found: $\mathrm{C}$, 73.54; H, 3.85; N, 12.98 .

6.1.11.5. 4-[(3-Chlorophenyl)amino]pyrrolo[1,2-a]quinoxaline-7carboxylic acid (1e). Beige crystals (96\%); $\mathrm{mp}>300{ }^{\circ} \mathrm{C}$. IR $(\mathrm{KBr})$ $3425(\mathrm{NH}), 3150-2600(\mathrm{COOH}), 1700$ (COO). ${ }^{1} \mathrm{H}$ NMR (DMSO-d 6 ) $\delta$ : 12.85 (bs, $1 \mathrm{H}, \mathrm{COOH}), 9.47(\mathrm{~s}, 1 \mathrm{H}, \mathrm{NH}), 8.41-8.38(\mathrm{~m}, 2 \mathrm{H}, \mathrm{H}-1$ and $\mathrm{H}-$ 6), $8.19(\mathrm{~d}, 1 \mathrm{H}, J=8.70 \mathrm{~Hz}, \mathrm{H}-9), 8.16\left(\mathrm{~d}, 1 \mathrm{H}, J=1.50 \mathrm{~Hz}, \mathrm{H}-2^{\prime}\right), 8.06$ (dd, $1 \mathrm{H}, J=8.70$ and $1.60 \mathrm{~Hz}, \mathrm{H}-8), 7.88(\mathrm{dd}, 1 \mathrm{H}, J=8.70$ and $1.50 \mathrm{~Hz}$, $\left.\mathrm{H}-6^{\prime}\right), 7.50(\mathrm{dd}, 1 \mathrm{H}, J=3.65$ and $1.20 \mathrm{~Hz}, \mathrm{H}-3), 7.40(\mathrm{t}, 1 \mathrm{H}, J=8.70 \mathrm{~Hz}$, $\left.\mathrm{H}-5^{\prime}\right), 7.08\left(\mathrm{dd}, 1 \mathrm{H}, J=8.70\right.$ and $\left.1.50 \mathrm{~Hz}, \mathrm{H}-4^{\prime}\right), 6.90(\mathrm{dd}, 1 \mathrm{H}, J=3.65$ and $3.00 \mathrm{~Hz}, \mathrm{H}-2) .{ }^{13} \mathrm{C}$ NMR (DMSO- $\left.d_{6}\right) \delta$ : $167.2,146.3,141.5,134.4$, 132.3, 129.6, 129.1, 127.4, 127.3, 124.3, 121.1, 118.9, 118.4, 117.9, 116.5, 113.7, 112.9, 105.4. Anal. Calcd. for $\mathrm{C}_{18} \mathrm{H}_{12} \mathrm{ClN}_{3} \mathrm{O}_{2}$ : C, 64.01; $\mathrm{H}, 3.58$; N, 12.44. Found: C, 64.28; H, 3.70; N, 12.63 .

6.1.11.6. 4-[(3-Ethynylphenyl)amino]pyrrolo[1,2-a]quinoxaline-7carboxylic acid (1f). Beige crystals (65\%); mp $280^{\circ} \mathrm{C}$. IR (KBr) 3400 (NH), 3250-2500 (COOH), 2100 ( $\mathrm{C} \equiv \mathrm{C}), 1685$ (COO). ${ }^{1} \mathrm{H}$ NMR (DMSO-d $\left.)_{6}\right) \delta: 13.07(\mathrm{~s}, 1 \mathrm{H}, \mathrm{COOH}), 9.36(\mathrm{~s}, 1 \mathrm{H}, \mathrm{NH}), 8.43-8.41(\mathrm{~m}$, $1 \mathrm{H}, \mathrm{H}-1), 8.28-8.15(\mathrm{~m}, 3 \mathrm{H}, \mathrm{H}-9, \mathrm{H}-6$ and $\mathrm{H}-8), 8.13(\mathrm{~d}, 1 \mathrm{H}$, $\left.J=1.70 \mathrm{~Hz}, \mathrm{H}-2^{\prime}\right), 7.86\left(\mathrm{dd}, 1 \mathrm{H}, J=8.30\right.$ and $\left.1.70 \mathrm{~Hz}, \mathrm{H}-6^{\prime}\right), 7.46$ (dd, $1 \mathrm{H}, J=3.80$ and $1.20 \mathrm{~Hz}, \mathrm{H}-3), 7.41\left(\mathrm{t}, 1 \mathrm{H}, J=8.30 \mathrm{~Hz}, \mathrm{H}-5^{\prime}\right), 7.16$ $\left(\mathrm{dd}, 1 \mathrm{H}, J=8.30\right.$ and $\left.1.70 \mathrm{~Hz}, \mathrm{H}-4^{\prime}\right), 6.91(\mathrm{dd}, 1 \mathrm{H}, J=3.80$ and $2.90 \mathrm{~Hz}, \mathrm{H}-2), 4.22(\mathrm{~s}, 1 \mathrm{H}, \mathrm{C} \equiv \mathrm{CH}) .{ }^{13} \mathrm{C}$ NMR (DMSO-d $\left.{ }_{6}\right) \delta: 166.6$, $146.5,140.1,134.7,128.4,127.8,127.4,127.3,124.8,124.1,122.6$, 121.2, 120.4, 118.4, 116.5, 113.9, 113.0, 105.4, 83.2, 79.7. Anal. Calcd. for $\mathrm{C}_{20} \mathrm{H}_{13} \mathrm{~N}_{3} \mathrm{O}_{2}$ : C, 73.38; $\mathrm{H}, 4.00 ; \mathrm{N}, 12.84$. Found: $\mathrm{C}, 73.51 ; \mathrm{H}$, 3.93; N, 12.99 .

6.1.11.7. 4-[(3-Chlorophenyl)amino]pyrrolo[1,2-a]quinoxaline-8carboxylic acid (1g). Beige crystals (81\%); mp $>300{ }^{\circ} \mathrm{C}$. IR (KBr) $3420(\mathrm{NH}), 3100-2600(\mathrm{COOH}), 1690(\mathrm{COO}) .{ }^{1} \mathrm{H}$ NMR (DMSO-d 6 ) $\delta$ : $9.50(\mathrm{~s}, 1 \mathrm{H}, \mathrm{NH}), 8.61(\mathrm{~d}, 1 \mathrm{H}, J=1.70 \mathrm{~Hz}, \mathrm{H}-9), 8.49-8.47(\mathrm{~m}, 1 \mathrm{H}, \mathrm{H}-$ 1), $8.34\left(\mathrm{t}, 1 \mathrm{H}, J=1.80 \mathrm{~Hz}, \mathrm{H}-2^{\prime}\right), 8.03(\mathrm{~d}, 1 \mathrm{H}, J=8.40 \mathrm{~Hz}, \mathrm{H}-7), 8.03$ $(\mathrm{d}, 1 \mathrm{H}, J=8.40 \mathrm{~Hz}, \mathrm{H}-7), 7.91\left(\mathrm{dd}, 1 \mathrm{H}, J=8.10\right.$ and $\left.1.80 \mathrm{~Hz}, \mathrm{H}-6^{\prime}\right), 7.62$ $(\mathrm{d}, 1 \mathrm{H}, J=8.40 \mathrm{~Hz}, \mathrm{H}-6), 7.46(\mathrm{dd}, 1 \mathrm{H}, J=3.90$ and $1.10 \mathrm{~Hz}, \mathrm{H}-3), 7.40$ $\left(\mathrm{t}, 1 \mathrm{H}, J=8.10 \mathrm{~Hz}, \mathrm{H}-5^{\prime}\right), 7.10\left(\mathrm{dd}, 1 \mathrm{H}, J=8.10\right.$ and $\left.1.80 \mathrm{~Hz}, \mathrm{H}-4^{\prime}\right), 6.87$ (dd, $1 \mathrm{H}, J=3.90$ and $3.00 \mathrm{~Hz}, \mathrm{H}-2), 3.39$ (bs, $1 \mathrm{H}, \mathrm{COOH}) .{ }^{13} \mathrm{C}$ NMR $\left(\right.$ DMSO- $_{6}$ ) $\delta: 166.7,147.1,141.3,138.1,132.3,129.6,129.5,125.9$, 125.7, 124.4, 121.4, 119.3, 118.3, 118.1, 116.6, 114.8, 112.6, 105.4. Anal. Calcd. for $\mathrm{C}_{18} \mathrm{H}_{12} \mathrm{ClN}_{3} \mathrm{O}_{2}$ : C, 64.01; H, 3.58; N, 12.44. Found: C, 63.86; $\mathrm{H}, 3.67 ; \mathrm{N}, 12.28$.

6.1.11.8. 4-[(3-Ethynylphenyl)amino]pyrrolo[1,2-a]quinoxaline-8carboxylic acid (1h). White crystals (76\%); mp $>300{ }^{\circ} \mathrm{C}$. IR $(\mathrm{KBr})$ $3390(\mathrm{NH}), 3150-2600(\mathrm{COOH}), 2100(\mathrm{C} \equiv \mathrm{C}), 1690(\mathrm{COO}) .{ }^{1} \mathrm{H}$ NMR (DMSO-d 6 ) $\delta: 9.43$ (s, 1H, NH), 8.62 (d, 1H, J = 1.80 Hz, H-9), 8.42$8.41(\mathrm{~m}, 1 \mathrm{H}, \mathrm{H}-1), 8.29\left(\mathrm{t}, 1 \mathrm{H}, J=1.75 \mathrm{~Hz}, \mathrm{H}-2^{\prime}\right), 8.19(\mathrm{~d}, 1 \mathrm{H}$, $J=8.20 \mathrm{~Hz}, \mathrm{H}-7), 7.93\left(\mathrm{~d}, 1 \mathrm{H}, J=8.40 \mathrm{~Hz}, \mathrm{H}-6^{\prime}\right), 7.58(\mathrm{~d}, 1 \mathrm{H}$, $J=8.20 \mathrm{~Hz}, \mathrm{H}-6), 7.54(\mathrm{dd}, 1 \mathrm{H}, J=3.80$ and $1.20 \mathrm{~Hz}, \mathrm{H}-3), 7.38(\mathrm{t}, 1 \mathrm{H}$, $\left.J=8.40 \mathrm{~Hz}, \mathrm{H}-5^{\prime}\right), 7.15\left(\mathrm{~d}, 1 \mathrm{H}, J=8.40 \mathrm{~Hz}, \mathrm{H}-4^{\prime}\right), 6.84(\mathrm{dd}, 1 \mathrm{H}, J=3.80$ and $3.00 \mathrm{~Hz}, \mathrm{H}-2), 4.21(\mathrm{~s}, 1 \mathrm{H}, \mathrm{C} \equiv \mathrm{CH}), 3.61(\mathrm{bs}, 1 \mathrm{H}, \mathrm{COOH}) .{ }^{13} \mathrm{C} \mathrm{NMR}$ (DMSO-d $\left._{6}\right) \delta$ : 168.0, 147.0, 140.1, 137.8, 128.5, 128.3, 125.7, 125.6, 124.9, 124.2, 122.8, 121.2, 120.6, 118.2, 116.2, 114.7, 112.5, 105.4, 83.2, 79.7. Anal. Calcd. for $\mathrm{C}_{20} \mathrm{H}_{13} \mathrm{~N}_{3} \mathrm{O}_{2}$ : $\mathrm{C}, 73.38 ; \mathrm{H}, 4.00 ; \mathrm{N}, 12.84$. Found: C, 73.44; H, 3.95; N, 12.80 . 
6.1.11.9. 4-[(3-Chlorophenyl)amino]pyrrolo[1,2-a]quinoxaline-9carboxylic acid (1i). Beige crystals (52\%); $\mathrm{mp}>300^{\circ} \mathrm{C}$. IR (KBr) 3410 (NH), 3100-2600 (COOH), $1690(\mathrm{COO}) .{ }^{1} \mathrm{H}$ NMR (DMSO-d 6$) \delta: 9.38$ $(\mathrm{s}, 1 \mathrm{H}, \mathrm{NH}), 8.31\left(\mathrm{t}, 1 \mathrm{H}, J=1.80 \mathrm{~Hz}, \mathrm{H}-2^{\prime}\right), 8.05-8.00\left(\mathrm{~m}, 1 \mathrm{H}, \mathrm{H}-6^{\prime}\right)$, $7.92(\mathrm{dd}, 1 \mathrm{H}, J=2.90$ and $1.20 \mathrm{~Hz}, \mathrm{H}-1), 7.66(\mathrm{dd}, 1 \mathrm{H}, J=7.50$ and $1.65 \mathrm{~Hz}, \mathrm{H}-6), 7.47$ (dd, $1 \mathrm{H}, J=4.05$ and $1.20 \mathrm{~Hz}, \mathrm{H}-3), 7.40-7.32(\mathrm{~m}$, $3 \mathrm{H}, \mathrm{H}-7, \mathrm{H}-8$ and $\left.\mathrm{H}-5^{\prime}\right), 7.08\left(\mathrm{dd}, 1 \mathrm{H}, J=7.50\right.$ and $\left.1.65 \mathrm{~Hz}, \mathrm{H}-4^{\prime}\right), 6.86$ (dd, $1 \mathrm{H}, J=4.05$ and $2.90 \mathrm{~Hz}, \mathrm{H}-2$ ), 3.43 (bs, $1 \mathrm{H}, \mathrm{COOH}) .{ }^{13} \mathrm{C} \mathrm{NMR}$ (DMSO-d ${ }_{6}$ ) $\delta: 171.1,147.2,142.5,137.0,133.3,130.6,129.1,125.3$, 124.5, 124.3, 122.2, 121.9, 120.1, 120.0, 119.7, 119.0, 133.3, 105.8. Anal. Calcd. for $\mathrm{C}_{18} \mathrm{H}_{12} \mathrm{ClN}_{3} \mathrm{O}_{2}$ : C, 64.01; $\mathrm{H}, 3.58 ; \mathrm{N}, 12.44$. Found: C, 63.98; $\mathrm{H}, 3.62 ; \mathrm{N}, 12.37$.

6.1.11.10. 4-[(3-Ethynylphenyl)amino]pyrrolo[1,2-a]quinoxaline-9carboxylic acid (1j). Beige crystals (75\%); mp $214^{\circ} \mathrm{C}$. IR (KBr) 3385 (NH), 3150-2650 (COOH), $2100(\mathrm{C} \equiv \mathrm{C}), 1690$ (COO). ${ }^{1} \mathrm{H}$ NMR (DMSO$\left.d_{6}\right) \delta: 9.20(\mathrm{~s}, 1 \mathrm{H}, \mathrm{NH}), 8.38(\mathrm{dd}, 1 \mathrm{H}, J=2.95$ and $1.20 \mathrm{~Hz}, \mathrm{H}-1), 8.27(\mathrm{t}$, $\left.1 \mathrm{H}, J=1.70 \mathrm{~Hz}, \mathrm{H}-2^{\prime}\right), 8.18$ (dd, $1 \mathrm{H}, J=7.40$ and $\left.1.50 \mathrm{~Hz}, \mathrm{H}-6^{\prime}\right), 7.46-$ $7.40(\mathrm{~m}, 2 \mathrm{H}, \mathrm{H}-3$ and $\mathrm{H}-6), 7.36(\mathrm{t}, 1 \mathrm{H}, J=7.95 \mathrm{~Hz}, \mathrm{H}-7), 7.23(\mathrm{t}, 1 \mathrm{H}$, $\left.J=7.65 \mathrm{~Hz}, \mathrm{H}-5^{\prime}\right), 7.12-7.10$ ( $\left.\mathrm{m}, 1 \mathrm{H}, \mathrm{H}-8\right), 7.07$ (dd, $1 \mathrm{H}, J=7.40$ and $\left.1.50 \mathrm{~Hz}, \mathrm{H}-4^{\prime}\right), 6.69$ (dd, $1 \mathrm{H}, J=3.90$ and $\left.2.95 \mathrm{~Hz}, \mathrm{H}-2\right), 4.19(\mathrm{~s}, 1 \mathrm{H}$, $\mathrm{C} \equiv \mathrm{CH}), 3.50$ (bs, $1 \mathrm{H}, \mathrm{COOH}) .{ }^{13} \mathrm{C}$ NMR (DMSO- $\left.d_{6}\right) \delta: 173.0,146.8,141.6$, 136.6, 133.0, 129.3, 125.4, 125.3, 124.9, 123.3, 122.8, 122.2, 121.1, 120.8, 120.6, 119.6, 111.9, 105.0, 84.4, 80.6. Anal. Calcd. for $\mathrm{C}_{20} \mathrm{H}_{13} \mathrm{~N}_{3} \mathrm{O}_{2}$ : C, 73.38; H, 4.00; N, 12.84. Found: C, 73.25; H, 3.85; N, 12.93 .

6.1.11.11. 7-[(3-Chlorophenyl)amino]pyrrolo[1,2-a]quinoxaline-4carboxylic acid (1k). Red crystals (56\%); mp $195{ }^{\circ} \mathrm{C}$. IR (KBr) 3405 (NH), 3300-2700 (COOH), 1675 (COO). ${ }^{1} \mathrm{H}$ NMR (DMSO-d $) \delta: 8.75$ (s, 1H, NH), 8.48-8.47 (m, 1H, H-1), 8.27 (d, 1H, J = 6.70 Hz, H-9), $7.66(\mathrm{~d}, 1 \mathrm{H}, J=1.80 \mathrm{~Hz}, \mathrm{H}-6), 7.43(\mathrm{dd}, 1 \mathrm{H}, J=6.70$ and $1.20 \mathrm{~Hz}, \mathrm{H}-8)$, $7.38-7.36(\mathrm{~m}, 1 \mathrm{H}, \mathrm{H}-3), 7.29\left(\mathrm{t}, 1 \mathrm{H}, J=6.10 \mathrm{~Hz}, \mathrm{H}-5^{\prime}\right), 7.13-7.09(\mathrm{~m}$, $2 \mathrm{H}, \mathrm{H}-4^{\prime}$ and $\left.\mathrm{H}-2^{\prime}\right), 6.98-6.96(\mathrm{~m}, 1 \mathrm{H}, \mathrm{H}-2), 6.89(\mathrm{~d}, 1 \mathrm{H}, J=6.10 \mathrm{~Hz}$, $\mathrm{H}-6^{\prime}$ ), 3.43 (bs, $\left.1 \mathrm{H}, \mathrm{COOH}\right) .{ }^{13} \mathrm{C}$ NMR (DMSO-d $\left.{ }_{6}\right) \delta$ : 165.9, 149.7, 145.0, 139.2, 135.1, 133.1, 130.3, 123.7, 121.6, 119.9, 118.4, 116.2, 115.0, 114.8, 114.6, 113.7, 113.3, 109.2. Anal. Calcd. for $\mathrm{C}_{18} \mathrm{H}_{12} \mathrm{ClN}_{3} \mathrm{O}_{2}$ : C, $64.01 ; \mathrm{H}, 3.58 ; \mathrm{N}, 12.44$. Found: C, 63.82; H, 3.62; N, 12.40 .

6.1.11.12. 7-[(3-Ethynylphenyl)amino]pyrrolo[1,2-a]quinoxaline-4carboxylic acid (1l). Orange crystals (73\%); mp $>300{ }^{\circ} \mathrm{C}$. IR $(\mathrm{KBr})$ $3355(\mathrm{NH}), 3400-2850(\mathrm{COOH}), 2100(\mathrm{C} \equiv \mathrm{C}), 1630$ (COO). ${ }^{1} \mathrm{H}$ NMR $\left(\right.$ DMSO- $\left.d_{6}\right) \delta: 8.49(\mathrm{~s}, 1 \mathrm{H}, \mathrm{NH}), 8.26-8.25(\mathrm{~m}, 1 \mathrm{H}, \mathrm{H}-1), 8.12(\mathrm{~d}, 1 \mathrm{H}$, $J=8.70 \mathrm{~Hz}, \mathrm{H}-9), 7.73(\mathrm{~d}, 1 \mathrm{H}, J=2.00 \mathrm{~Hz}, \mathrm{H}-6), 7.29-7.14(\mathrm{~m}, 5 \mathrm{H}, \mathrm{H}-$ 3, $\mathrm{H}-2^{\prime}, \mathrm{H}-4^{\prime}, \mathrm{H}-5^{\prime}$ and $\left.\mathrm{H}-8\right), 6.91$ (d, $\left.1 \mathrm{H}, J=7.10 \mathrm{~Hz}, \mathrm{H}-6^{\prime}\right), 6.81$ (dd, $1 \mathrm{H}, J=3.85$ and $2.70 \mathrm{~Hz}, \mathrm{H}-2), 4.10(\mathrm{~s}, 1 \mathrm{H}, \mathrm{C} \equiv \mathrm{CH}), 3.41$ (bs, $1 \mathrm{H}$, COOH). ${ }^{13} \mathrm{C}$ NMR (DMSO- $\left.d_{6}\right) \delta: 167.5,154.4,144.7,140.1,136.7,130.1$, 125.1, 123.1, 123.0, 122.4, 119.9, 119.0, 117.4, 116.8, 115.7, 115.0, 113.7, 110.1, 84.3, 80.6. Anal. Calcd. for $\mathrm{C}_{20} \mathrm{H}_{13} \mathrm{~N}_{3} \mathrm{O}_{2}$ : C, 73.38; $\mathrm{H}, 4.00 ; \mathrm{N}$, 12.84. Found: C, 73.56; H, 3.89; N, 12.93 .

6.1.11.13. 4-[(3-Chlorophenyl)amino]-2-(3-pyridyl)pyrrolo[1,2-a]quinoxaline-7-carboxylic acid $(\mathbf{1 m})$. Beige crystals (92\%); $\mathrm{mp}>300{ }^{\circ} \mathrm{C}$. IR (KBr) $3385(\mathrm{NH}), 3600-3000(\mathrm{COOH}), 1690$ (COO). ${ }^{1} \mathrm{H}$ NMR $\left(\mathrm{DMSO}_{-} \mathrm{d}_{6}\right) \delta: 9.59(\mathrm{~s}, 1 \mathrm{H}, \mathrm{NH}), 9.07-9.06(\mathrm{~m}, 1 \mathrm{H}, \mathrm{H}-1), 8.99-8.98$ ( $\mathrm{m}, 1 \mathrm{H}, \mathrm{H}-6), 8.49-8.48\left(\mathrm{~m}, 2 \mathrm{H}, \mathrm{H}-4^{\prime}\right.$ and $\left.\mathrm{H}-9\right), 8.17-8.16(\mathrm{~m}, 2 \mathrm{H}, \mathrm{H}-$ $6^{\prime}$ and $\left.\mathrm{H}_{-} \mathrm{2}^{\prime}\right), 8.12-8.10\left(\mathrm{~m}, 2 \mathrm{H}, \mathrm{H}-2^{\prime \prime}\right.$ and $\left.\mathrm{H}-8\right), 7.94-7.92(\mathrm{~m}, 2 \mathrm{H}, \mathrm{H}-$ 3 and $\left.\mathrm{H}-6^{\prime \prime}\right), 7.51-7.48\left(\mathrm{~m}, 1 \mathrm{H}, \mathrm{H}-5^{\prime}\right), 7.42-7.40\left(\mathrm{~m}, 1 \mathrm{H}, \mathrm{H}-5^{\prime \prime}\right), 7.09-$ 7.07 (m, 1H, H-4"), 3.42 (bs, $1 \mathrm{H}, \mathrm{COOH}) .{ }^{13} \mathrm{C}$ NMR (DMSO-d 6 ) $\delta$ : 169.3, 148.4, 147.3, 146.8, 143.0, 139.2, 135.2, 133.5, 133.1, 130.7, 130.6, 128.5, 126.2, 126.1, 125.0, 124.7, 121.9, 120.6, 119.8, 118.7, 114.4, 113.8, 103.0. Anal. Calcd. for $\mathrm{C}_{23} \mathrm{H}_{15} \mathrm{ClN}_{4} \mathrm{O}_{2}$ : C, 66.59; $\mathrm{H}, 3.64 ; \mathrm{N}$, 13.51. Found: C, 66.72; H, 3.62; N, 13.43 .

6.1.11.14. 4-[(3-Ehtynylphenyl)amino]-2-(3-pyridyl)pyrrolo[1,2-a] quinoxaline-7-carboxylic acid (1n). Beige crystals (83\%); mp $>300^{\circ} \mathrm{C}$. IR (KBr) $3355(\mathrm{NH}), 3650-2900(\mathrm{COOH}), 2105(\mathrm{C} \equiv \mathrm{C}), 1695$ (COO). ${ }^{1} \mathrm{H}$ NMR (DMSO-d $) \delta: 13.04(\mathrm{~s}, 1 \mathrm{H}, \mathrm{COOH}), 9.54(\mathrm{~s}, 1 \mathrm{H}, \mathrm{NH})$, 9.07 (s, 1H, H-1), 9.06 (s, 1H, H-6), 8.54-8.53 (m, 1H, H-4'), 8.32 (s, $\left.1 \mathrm{H}, \mathrm{H}-2^{\prime}\right), 8.27-8.22\left(\mathrm{~m}, 2 \mathrm{H}, \mathrm{H}-6^{\prime}\right.$ and $\left.\mathrm{H}-9\right), 8.19-8.17(\mathrm{~m}, 1 \mathrm{H}, \mathrm{H}-8)$, $8.14\left(\mathrm{~s}, 1 \mathrm{H}, \mathrm{H}-2^{\prime \prime}\right), 8.01$ (s, 1H, H-3), 7.92-7.90 (m, 1H, H-6" $\left.{ }^{\prime \prime}\right), 7.56-$ 7.53 ( $\left.\mathrm{m}, 1 \mathrm{H}, \mathrm{H}-5^{\prime}\right), 7.44-7.41$ ( $\left.\mathrm{m}, 1 \mathrm{H}, \mathrm{H}-5^{\prime \prime}\right), 7.19-7.17$ (m, 1H, H-4" ${ }^{\prime \prime}$, $4.20(\mathrm{~s}, 1 \mathrm{H}, \mathrm{C} \equiv \mathrm{CH}) .{ }^{13} \mathrm{C}$ NMR (DMSO- $\left.d_{6}\right) \delta: 167.5,148.2,147.4,146.9$, 141.2, 135.9, 133.4, 130.4, 129.6, 128.7, 128.6, 128.4, 126.1, 125.5, 125.4, 124.8, 123.6, 122.4, 121.4, 120.7, 115.2, 115.1, 104.0, 84.4, 80.9. Anal. Calcd. for $\mathrm{C}_{25} \mathrm{H}_{16} \mathrm{~N}_{4} \mathrm{O}_{2}$ : C, 74.25; $\mathrm{H}, 3.99 ; \mathrm{N}, 13.85$. Found: $\mathrm{C}$, 74.09; H, 3.82; N, 13.75 .

\subsubsection{1-(4-Bromo-2-nitrophenyl)pyrrole (13)}

A mixture of 4-bromo-2-nitroaniline $(23 \mathrm{mmol})$ and 2,5dimethoxytetrahydrofuran $(25 \mathrm{mmol})$ in acetic acid $(65 \mathrm{~mL})$ was refluxed for $1 \mathrm{~h}$ with vigourous stirring. After cooling, the reaction mixture was poured into water. The mixture was then extracted twice with diethyl ether. The organic layer was dried over sodium sulfate and evaporated to dryness under reduced pressure to give 13. Orange oil (86\%). ${ }^{1} \mathrm{H}$ NMR $\left(\mathrm{CDCl}_{3}\right) \delta: 8.00(\mathrm{~d}, 1 \mathrm{H}, J=2.20 \mathrm{~Hz}$, $\mathrm{H}-3), 7.78(\mathrm{dd}, 1 \mathrm{H}, J=8.55$ and $2.20 \mathrm{~Hz}, \mathrm{H}-5), 7.36(\mathrm{~d}, 1 \mathrm{H}, J=8.55 \mathrm{~Hz}$, $\mathrm{H}-6), 6.78(\mathrm{dd}, 2 \mathrm{H}, J=1.85$ and $1.85 \mathrm{~Hz}, 2 \mathrm{H}-\alpha), 6.39$ (dd, $2 \mathrm{H}, J=1.85$ and $1.85 \mathrm{~Hz}, 2 \mathrm{H}-\beta)$. Anal. Calcd. for $\mathrm{C}_{10} \mathrm{H}_{7} \mathrm{BrN}_{2} \mathrm{O}_{2}$ : C, 44.97; $\mathrm{H}, 2.64$; $\mathrm{N}, 10.49$. Found: C, 45.12; H, 2.85; N, 10.38 .

\subsubsection{1-(2-Amino-4-bromophenyl)pyrrole (14)}

To a solution of 1-(4-bromo-2-nitrophenyl)pyrrole (13) (19 mmol) in ethanol (95 mL) was added $15 \mathrm{~mL}$ of a $2 \mathrm{M}$ aqueous solution of $\mathrm{CuSO}_{4}$. Sodium borohydride $(94 \mathrm{mmol}$ ) was added portion-wise at $0{ }^{\circ} \mathrm{C}$ to the reaction mixture which was then stirred at room temperature for $1 \mathrm{~h}$. The reaction mixture was then diluted with ethyl acetate and filtered. The organic layer was separated, dried over $\mathrm{Na}_{2} \mathrm{SO}_{4}$ and evaporated to dryness under reduced pressure to give 14 . Orange crystals $(90 \%) ; \mathrm{mp} 67^{\circ} \mathrm{C}$. IR (KBr) 3380 and $3300\left(\mathrm{NH}_{2}\right) .{ }^{1} \mathrm{H}$ NMR $\left(\mathrm{CDCl}_{3}\right) \delta: 7.01(\mathrm{~d}, 1 \mathrm{H}, J=8.10 \mathrm{~Hz}, \mathrm{H}-6)$, $6.97(\mathrm{~d}, 1 \mathrm{H}, J=1.80 \mathrm{~Hz}, \mathrm{H}-3), 6.92(\mathrm{dd}, 1 \mathrm{H}, J=8.10$ and $1.80 \mathrm{~Hz}, \mathrm{H}-5)$, $6.81(\mathrm{dd}, 2 \mathrm{H}, J=1.80$ and $1.80 \mathrm{~Hz}, 2 \mathrm{H}-\alpha), 6.36(\mathrm{dd}, 2 \mathrm{H}, J=1.80$ and $1.80 \mathrm{~Hz}, 2 \mathrm{H}-\beta$ ), 3.81 (bs, $2 \mathrm{H}, \mathrm{NH}_{2}$ ). Anal. Calcd. for $\mathrm{C}_{10} \mathrm{H}_{9} \mathrm{BrN}_{2}$ : C, 50.66; H, 3.83; N, 11.82. Found: C, 50.85; H, 4.02; N, 11.97 .

\subsubsection{Ethyl 2-[(5-bromo-2-pyrrolo-1-ylphenyl)amino]-2-oxo- acetate (15)}

To a solution containing 1-(2-amino-4-bromophenyl)pyrrole (14) $(17 \mathrm{mmol})$ in $140 \mathrm{~mL}$ of $\mathrm{THF}$ at $0{ }^{\circ} \mathrm{C}$ was added $\mathrm{Et}_{3} \mathrm{~N}(17 \mathrm{mmol})$ followed by ethyl oxalylchloride $(17 \mathrm{mmol}$ ) dropwise over $15 \mathrm{~min}$. The reaction mixture was warmed to room temperature and stirred for $14 \mathrm{~h}$. The reaction mixture was filtered and the filter cake was washed with THF then with ethyl acetate. The organic phase was washed twice with $25 \mathrm{~mL}$ of a $1 \mathrm{M} \mathrm{HCl}$ aqueous solution, dried over sodium sulfate, filtered, and concentrated. The crude residue was cooled, triturated with diethyl ether and filtered to give 15. Beige crystals (43\%); mp $70{ }^{\circ} \mathrm{C}$. IR ( KBr) $3280(\mathrm{NH}), 1690$ and $1680(\mathrm{CO}) .{ }^{1} \mathrm{H}$ $\operatorname{NMR}\left(\mathrm{CDCl}_{3}\right) \delta: 8.90(\mathrm{~s}, 1 \mathrm{H}, \mathrm{NH}), 8.75(\mathrm{~d}, 1 \mathrm{H}, J=1.80 \mathrm{~Hz}, \mathrm{H}-6), 7.40$ (dd, $1 \mathrm{H}, J=8.40$ and $1.80 \mathrm{~Hz}, \mathrm{H}-5), 7.23(\mathrm{~d}, 1 \mathrm{H}, J=8.40 \mathrm{~Hz}, \mathrm{H}-3), 6.80$ $(\mathrm{dd}, 2 \mathrm{H}, J=1.80$ and $1.80 \mathrm{~Hz}, 2 \mathrm{H}-\alpha), 6.48(\mathrm{dd}, 2 \mathrm{H}, J=1.80$ and $1.80 \mathrm{~Hz}, 2 \mathrm{H}-\beta), 4.36\left(\mathrm{q}, 2 \mathrm{H}, J=7.20 \mathrm{~Hz}, \mathrm{OCH}_{2}\right), 1.39(\mathrm{t}, 3 \mathrm{H}$, $J=7.20 \mathrm{~Hz}, \mathrm{CH}_{3}$ ). Anal. Calcd. for $\mathrm{C}_{14} \mathrm{H}_{13} \mathrm{BrN}_{2} \mathrm{O}_{3}: \mathrm{C}, 49.87 ; \mathrm{H}, 3.89 ; \mathrm{N}$, 8.31. Found: C, 50.04; H, 3.73; N, 8.35.

\subsubsection{Ethyl 4-bromopyrrolo[1,2-a]quinoxaline-4-carboxylate (16)}

A solution of ethyl 2-[(5-bromo-2-pyrrolo-1-ylphenyl)amino]2-oxo-acetate $(15)(7 \mathrm{mmol})$ in $\mathrm{POCl}_{3}(10 \mathrm{~mL})$ was refluxed for $20 \mathrm{~min}$. After removing excess of reactive under vacuum, the residue was carefully dissolved in water at $0{ }^{\circ} \mathrm{C}$ and the resulting solution was made basic with ammonium hydroxide. The precipitate 
was filtered, washed with diethyl ether, and dried to give 16. Yellow crystals (70\%); mp $159{ }^{\circ} \mathrm{C}$. IR ( $\left.\mathrm{KBr}\right) 1735$ (COO). ${ }^{1} \mathrm{H}$ NMR $\left(\mathrm{CDCl}_{3}\right) \delta$ : $8.33(\mathrm{~d}, 1 \mathrm{H}, J=2.10 \mathrm{~Hz}, \mathrm{H}-6), 8.03(\mathrm{dd}, 1 \mathrm{H}, J=2.80$ and $1.20 \mathrm{~Hz}, \mathrm{H}-1)$, $7.79(\mathrm{~d}, 1 \mathrm{H}, J=8.90 \mathrm{~Hz}, \mathrm{H}-9), 7.72(\mathrm{dd}, 1 \mathrm{H}, J=8.90$ and $2.10 \mathrm{~Hz}, \mathrm{H}-8)$, 7.57 (dd, $1 \mathrm{H}, J=3.90$ and $1.20 \mathrm{~Hz}, \mathrm{H}-3$ ), 7.03 (dd, $1 \mathrm{H}, J=3.90$ and $2.80 \mathrm{~Hz}, \mathrm{H}-2), 4.60$ (q, $\left.2 \mathrm{H}, J=7.20 \mathrm{~Hz}, \mathrm{OCH}_{2}\right), 1.54(\mathrm{t}, 3 \mathrm{H}, J=7.20 \mathrm{~Hz}$, $\mathrm{CH}_{3}$ ). Anal. Calcd. for $\mathrm{C}_{14} \mathrm{H}_{11} \mathrm{BrN}_{2} \mathrm{O}_{2}$ : C, 52.69; $\mathrm{H}, 3.47 ; \mathrm{N}, 8.78$. Found: C, 52.78; H, 3.33; N, 8.89.

\subsubsection{Ethyl 7-[(3-ethynylphenyl)amino]pyrrolo[1,2-a]quinoxaline-}

4-carboxylate (17)

To a solution of ethyl 7-\{[3-(2-trimethylsilylethynyl)phenyl] amino\}pyrrolo[1,2-a]quinoxaline-4-carboxylate $(\mathbf{1 2 1})(0.5 \mathrm{mmol})$ in THF $(5 \mathrm{~mL})$, cooled to $-20^{\circ} \mathrm{C}, 0.6 \mathrm{~mL}$ of a $1 \mathrm{M}$ tetrabutylammonium fluoride solution in THF was added and the mixture was stirred for $1 \mathrm{~h}$. The mixture was diluted with water and extracted twice with ethyl acetate. The extract was washed with water, brine, dried with sodium sulfate and evaporated to leave an orange solid which was purified by column chromatography (silica gel, cyclohexane/ethyl acetate, $7 / 3, \mathrm{v} / \mathrm{v})$. Orange crystals $(69 \%) ; \mathrm{mp} 68{ }^{\circ} \mathrm{C}$. IR (KBr) 3420 $(\mathrm{NH}), 2105(\mathrm{C} \equiv \mathrm{C}), 1720$ (COO). ${ }^{1} \mathrm{H}$ NMR $\left(\mathrm{CDCl}_{3}\right) \delta: 7.95(\mathrm{dd}, 1 \mathrm{H}$, $J=2.55$ and $1.20 \mathrm{~Hz}, \mathrm{H}-1), 7.80(\mathrm{~d}, 1 \mathrm{H}, J=2.10 \mathrm{~Hz}, \mathrm{H}-6), 7.78(\mathrm{~d}, 1 \mathrm{H}$, $J=8.40 \mathrm{~Hz}, \mathrm{H}-9), 7.51(\mathrm{dd}, 1 \mathrm{H}, J=4.05$ and $1.20 \mathrm{~Hz}, \mathrm{H}-3), 7.33$ (dd, $1 \mathrm{H}, J=8.40$ and $2.10 \mathrm{~Hz}, \mathrm{H}-8), 7.25\left(\mathrm{t}, 1 \mathrm{H}, J=1.70 \mathrm{~Hz}, \mathrm{H}-2^{\prime}\right), 7.24(\mathrm{t}$, $\left.1 \mathrm{H}, J=8.10 \mathrm{~Hz}, \mathrm{H}-5^{\prime}\right), 7.15-7.09\left(\mathrm{~m}, 2 \mathrm{H}, \mathrm{H}-4^{\prime}\right.$ and $\left.\mathrm{H}-6^{\prime}\right), 6.96(\mathrm{dd}, 1 \mathrm{H}$, $J=4.05$ and $2.55 \mathrm{~Hz}, \mathrm{H}-2), 6.28(\mathrm{~s}, 1 \mathrm{H}, \mathrm{NH}), 4.54(\mathrm{q}, 2 \mathrm{H}, J=6.90 \mathrm{~Hz}$, $\left.\mathrm{OCH}_{2}\right), 1.46\left(\mathrm{t}, 3 \mathrm{H}, J=6.90 \mathrm{~Hz}, \mathrm{CH}_{3}\right)$. Anal. Calcd. for $\mathrm{C}_{22} \mathrm{H}_{17} \mathrm{~N}_{3} \mathrm{O}_{2}: \mathrm{C}$, 74.35; H, 4.82; N, 11.82. Found: C, 74.52; H, 5.06; N, 11.94.

\subsubsection{Ethyl 7-[2-(3-aminophenyl)ethynyl]pyrrolo[1,2-a] quinoxaline-4-carboxylate (18)}

A mixture of 7-bromopyrrolo[1,2-a]quinoxaline (16) (3 mmol), 3-ethynylaniline $(3.6 \mathrm{mmol}), \mathrm{Cs}_{2} \mathrm{CO}_{3}(4.2 \mathrm{mmol}), \mathrm{Pd}(\mathrm{OAc})_{2}$ $(0.15 \mathrm{mmol})$ and BINAP $(0.225 \mathrm{mmol})$ in $15 \mathrm{~mL}$ of toluene was heated at $100{ }^{\circ} \mathrm{C}$ for $20 \mathrm{~h}$. The reaction mixture was allowed to cool to room temperature, diluted with dichloromethane and filtered through a pad of Celite and the filter cake was washed with dichloromethane $(\times 3)$. Concentration and flash chromatography on silica gel using AcOEt/cyclohexane (3/7, v/v) as eluent afforded 18. Orange crystals (22\%); mp $145^{\circ} \mathrm{C}$. IR (KBr) 3410 and $3330\left(\mathrm{NH}_{2}\right)$, $2210(\mathrm{C} \equiv \mathrm{C}), 1725$ (COO). ${ }^{1} \mathrm{H}$ NMR $\left(\mathrm{CDCl}_{3}\right) \delta: 8.32(\mathrm{~d}, 1 \mathrm{H}, J=1.80 \mathrm{~Hz}$, $\mathrm{H}-6), 8.03(\mathrm{dd}, 1 \mathrm{H}, J=2.70$ and $1.20 \mathrm{~Hz}, \mathrm{H}-1), 7.88(\mathrm{~d}, 1 \mathrm{H}, J=8.40 \mathrm{~Hz}$, $\mathrm{H}-9), 7.76(\mathrm{dd}, 1 \mathrm{H}, J=8.10$ and $1.80 \mathrm{~Hz}, \mathrm{H}-8), 7.57(\mathrm{dd}, 1 \mathrm{H}, J=4.05$ and $1.20 \mathrm{~Hz}, \mathrm{H}-3$ ), $7.18\left(\mathrm{t}, 1 \mathrm{H}, J=8.10 \mathrm{~Hz}, \mathrm{H}-5^{\prime}\right), 7.03(\mathrm{dd}, 1 \mathrm{H}, J=4.05$ and $2.70 \mathrm{~Hz}, \mathrm{H}-2), 7.01-6.98\left(\mathrm{~m}, 1 \mathrm{H}, \mathrm{H}-6^{\prime}\right), 6.91(\mathrm{t}, 1 \mathrm{H}, J=1.80 \mathrm{~Hz}, \mathrm{H}-$ $\left.2^{\prime}\right), 6.73-6.69\left(\mathrm{~m}, 1 \mathrm{H}, \mathrm{H}-4^{\prime}\right), 4.62\left(\mathrm{q}, 2 \mathrm{H}, J=7.20 \mathrm{~Hz}, \mathrm{OCH}_{2}\right), 3.75(\mathrm{~s}$, $\left.2 \mathrm{H}, \mathrm{NH}_{2}\right), 1.55\left(\mathrm{t}, 3 \mathrm{H}, J=7.20 \mathrm{~Hz}, \mathrm{CH}_{3}\right)$. Anal. Calcd. for $\mathrm{C}_{22} \mathrm{H}_{17} \mathrm{~N}_{3} \mathrm{O}_{2}$ : C, 74.35; H, 4.82; N, 11.82. Found: C, 74.28; H, 5.01; N, 11.89.

\subsubsection{7-[2-(3-Aminophenyl)ethynyl]pyrrolo[1,2-a]quinoxaline-4-} carboxylic acid (19)

A mixture of ethyl 7-[2-(3-aminophenyl)ethynyl]pyrrolo[1,2-a] quinoxaline-4-carboxylate (18) $(0.6 \mathrm{mmol})$ in methanol $(12 \mathrm{~mL})$ and a $\mathrm{NaOH}$ aqueous solution $(4.8 \mathrm{mmol}$ in $8 \mathrm{~mL}$ ) was refluxed for $4 \mathrm{~h}$. On cooling, after removal of the solvent under reduced pressure, the residue was diluted with water and adjusted to $\mathrm{pH}=6$ with $1 \mathrm{M} \mathrm{HCl}$ aqueous solution. The solid precipitate was filtered off and washed with water then with diethyl ether, and purified by column chromatography using $\mathrm{CH}_{2} \mathrm{Cl}_{2} /$ methanol $(9 / 1, \mathrm{v} / \mathrm{v})$ as eluent to give 19. Beige crystals (45\%); $\mathrm{mp}>300^{\circ} \mathrm{C}$. IR ( KBr) 3500-2900 (COOH), 3400 and $3340\left(\mathrm{NH}_{2}\right), 2205(\mathrm{C} \equiv \mathrm{C}), 1695(\mathrm{COO}) .{ }^{1} \mathrm{H}$ NMR (DMSO-d 6$) \delta$ : $10.21(\mathrm{~s}, 1 \mathrm{H}, \mathrm{COOH}), 8.42-8.40(\mathrm{~m}, 1 \mathrm{H}, \mathrm{H}-1), 8.26(\mathrm{~d}, 1 \mathrm{H}, J=7.80 \mathrm{~Hz}$, $\mathrm{H}-9), 8.10(\mathrm{~s}, 1 \mathrm{H}, \mathrm{H}-6), 7.67$ (d, $1 \mathrm{H}, J=7.80 \mathrm{~Hz}, \mathrm{H}-8), 7.30-7.29(\mathrm{~m}, 1 \mathrm{H}$, $\mathrm{H}-3), 7.07\left(\mathrm{t}, 1 \mathrm{H}, J=7.60 \mathrm{~Hz}, \mathrm{H}-5^{\prime}\right), 6.91-6.90(\mathrm{~m}, 1 \mathrm{H}, \mathrm{H}-2), 6.77(\mathrm{~s}, 1 \mathrm{H}$, $\left.\mathrm{H}-2^{\prime}\right), 6.72\left(\mathrm{~d}, 1 \mathrm{H}, J=7.60 \mathrm{~Hz}, \mathrm{H}-6^{\prime}\right), 6.61\left(\mathrm{~d}, 1 \mathrm{H}, J=7.60 \mathrm{~Hz}, \mathrm{H}-4^{\prime}\right), 5.28$ $\left(\mathrm{s}, 2 \mathrm{H}, \mathrm{NH}_{2}\right.$ ). ${ }^{13} \mathrm{C}$ NMR (DMSO- $\left.d_{6}\right) \delta: 165.8,148.4,134.7,131.8,129.8$, $128.8,126.9,124.2,121.9,118.5,118.3,115.7,115.3,114.6,114.2,113.8$, 109.8, 104.1, 89.9, 87.0. Anal. Calcd. for $\mathrm{C}_{20} \mathrm{H}_{13} \mathrm{~N}_{3} \mathrm{O}_{2}$ : C, 73.38; $\mathrm{H}, 4.00$; $\mathrm{N}, 12.84$. Found: C, 73.21; H, 4.18; N, 12.94 .

\subsubsection{Methyl 4-(3-pyridyl)-1H-pyrrole-2-carboxylate (22)}

To suspension of 4-bromopyrrole-1,2-dicarboxylic acid 1-tertbutyl ester 2-methyl ester (21) $(10 \mathrm{mmol})$, and $\mathrm{Pd}\left(\mathrm{PPh}_{3}\right)_{4}$ $(0.5 \mathrm{mmol})$ in a mixture of toluene/EtOH $(120 / 6 \mathrm{~mL})$ under nitrogen were added $\mathrm{K}_{2} \mathrm{CO}_{3}(11 \mathrm{mmol})$ and 3-pyridylboronic acid (11 mmol). The reaction mixture was refluxed for $24 \mathrm{~h}$, and the cooled suspension was extracted with $\mathrm{CH}_{2} \mathrm{Cl}_{2}(3 \times 100 \mathrm{~mL})$. The organic layer was washed with a saturated solution of $\mathrm{NaCl}(150 \mathrm{~mL})$, and the combined organic extracts were dried over sodium sulfate, filtered, and evaporated under reduced pressure. The crude residue was solubilized in $40 \mathrm{~mL}$ of dichloromethane. To this reaction mixture was added $100 \mathrm{~mL}$ of a $10 \%$ trifluoroacetic acid solution in dichloromethane. The mixture was stirred at room temperature for $4 \mathrm{~h}$, then neutralized with $300 \mathrm{~mL}$ of a saturated aqueous solution of potassium carbonate and extracted with $120 \mathrm{~mL}$ of dichloromethane. The organic layer was washed with water, then brine and dried with anhydrous sodium sulfate. The solvent was removed under reduced pressure. The residue was triturated in methanol, then the resulting precipitate was filtered, washed with $\mathrm{MeOH}$ and dried to give 22. White crystals (34\%); mp $177{ }^{\circ} \mathrm{C}$. IR (KBr) 3390 $(\mathrm{NH}), 1700$ (COO). ${ }^{1} \mathrm{H}$ NMR $\left(\mathrm{CDCl}_{3}\right) \delta: 10.30(\mathrm{~s}, 1 \mathrm{H}, \mathrm{NH}), 8.83(\mathrm{~s}, 1 \mathrm{H}$, $\mathrm{H}-3), 8.48\left(\mathrm{~d}, 1 \mathrm{H}, J=4.50 \mathrm{~Hz}, \mathrm{H}-4^{\prime}\right), 7.80\left(\mathrm{~d}, 1 \mathrm{H}, J=7.80 \mathrm{~Hz}, \mathrm{H}-6^{\prime}\right)$, 7.33-7.28 (m, 2H, H-2' and $\left.\mathrm{H}-6^{\prime}\right), 7.23$ (s, $\left.1 \mathrm{H}, \mathrm{H}-5\right), 3.90(\mathrm{~s}, 3 \mathrm{H}$, $\mathrm{OCH}_{3}$ ). Anal. Calcd. for $\mathrm{C}_{11} \mathrm{H}_{10} \mathrm{~N}_{2} \mathrm{O}_{2}$ : C, 65.34; $\mathrm{H}, 4.98 ; \mathrm{N}, 13.85$. Found: C, 65.52; H, 5.06; N, 13.98 .

\subsubsection{Methyl 1-(4-ethoxycarbonyl-2-nitrophenyl)-4-(3-pyridyl)-} 1H-pyrrole-2-carboxylate (23)

To the solution of methyl 4-(3-pyridyl)- $1 \mathrm{H}$-pyrrole-2carboxylate (22) $(3.3 \mathrm{mmol})$ in $12 \mathrm{~mL}$ of DMF was added cesium carbonate $(4 \mathrm{mmol})$. The mixture was stirred at room temperature for $10 \mathrm{~min}$, then ethyl 4-fluoro-3-nitrobenzoate $(4 \mathrm{mmol})$ was added. The reaction mixture was refluxed for $1 \mathrm{~h} 30 \mathrm{~min}$ was then diluted in AcOEt $(50 \mathrm{~mL})$, was washed with water $(2 \times 50 \mathrm{~mL})$, then brine $(50 \mathrm{~mL})$ and dried over sodium sulfate. The organic layer was concentrated under vacuo to give a brown oil. After triturating in $\mathrm{Et}_{2} \mathrm{O}$ a solid was obtained and filtered off, washed with $\mathrm{Et}_{2} \mathrm{O}$ and dried to give the desired product 23 . Orange crystals (69\%); mp $163^{\circ} \mathrm{C}$. IR ( $\left.\mathrm{KBr}\right) 1710$ (COO). ${ }^{1} \mathrm{H}$ NMR $\left(\mathrm{CDCl}_{3}\right) \delta: 8.85$ (s, $\left.1 \mathrm{H}, \mathrm{H}-3\right), 8.80$ $\left(\mathrm{d}, 1 \mathrm{H}, J=1.80 \mathrm{~Hz}, \mathrm{H}-3^{\prime}\right), 8.54-8.52\left(\mathrm{~m}, 1 \mathrm{H}, \mathrm{H}-4^{\prime \prime}\right), 8.41(\mathrm{dd}, 1 \mathrm{H}$, $J=8.20$ and $\left.1.80 \mathrm{~Hz}, \mathrm{H}-5^{\prime}\right), 7.84\left(\mathrm{~d}, 1 \mathrm{H}, J=7.80 \mathrm{~Hz}, \mathrm{H}-6^{\prime \prime}\right), 7.59(\mathrm{~d}, 1 \mathrm{H}$, $\left.J=8.20 \mathrm{~Hz}, \mathrm{H}-6^{\prime}\right), 7.45$ (d, $\left.1 \mathrm{H}, J=1.80 \mathrm{~Hz}, \mathrm{H}-2^{\prime \prime}\right), 7.35$ (dd, $1 \mathrm{H}$, $J=7.80$ and $\left.4.90 \mathrm{~Hz}, \mathrm{H}-5^{\prime \prime}\right), 7.29(\mathrm{~s}, 1 \mathrm{H}, \mathrm{H}-5), 4.49(\mathrm{q}, 2 \mathrm{H}, J=6.90 \mathrm{~Hz}$, $\left.\mathrm{OCH}_{2}\right), 3.75\left(\mathrm{~s}, 3 \mathrm{H}, \mathrm{OCH}_{3}\right), 1.47\left(\mathrm{t}, 3 \mathrm{H}, J=6.90 \mathrm{~Hz}, \mathrm{CH}_{3}\right)$. Anal. Calcd. for $\mathrm{C}_{20} \mathrm{H}_{17} \mathrm{~N}_{3} \mathrm{O}_{6}$ : C, 60.76; $\mathrm{H}, 4.33 ; \mathrm{N}, 10.63$. Found: $\mathrm{C}, 60.83 ; \mathrm{H}, 4.38$; $\mathrm{N}, 10.52$.

\subsection{X-ray data}

The structure of compounds $\mathbf{1 f}, \mathbf{1 6}$ and $\mathbf{2 2}$ has been established by X-ray crystallography (Figs. 3-5). Colorless single crystal $\left(0.10 \times 0.06 \times 0.05 \mathrm{~mm}^{3}\right)$ of $\mathbf{1 f}$ was obtained by slow evaporation from methanol/chloroform (30/70) solution: monoclinic, space group $P 21 / n, a=4.8092(4) \AA, b=33.851(3) \AA, c=9.6672(8) \AA$, $\alpha=90^{\circ}, \beta=101.440(6)^{\circ}, \gamma=90^{\circ}, V=1542.5(2) \AA^{3}, Z=4$, $\delta$ (calcd) $=1.410 \mathrm{Mg} \mathrm{m}{ }^{-3}, F W=327.33$ for $\mathrm{C}_{20} \mathrm{H}_{13} \mathrm{~N}_{3} \mathrm{O}_{2}$, $F(000)=680$. Yellow single crystal $\left(0.12 \times 0.07 \times 0.07 \mathrm{~mm}^{3}\right)$ of $\mathbf{1 6}$ was obtained by slow evaporation from methanol/dichloromethane (30/70) solution: monoclinic, space group $P 21 / c$, $a=4.047(3) \AA, b=21.371(3) \AA, c=14.738(4) \AA, \alpha=90^{\circ}$, 
$\beta=96.03(3)^{\circ}, \quad \gamma=90^{\circ}, \quad V=1267.6(10) \AA^{3}, Z=4$, $\delta($ calcd $)=1.672 \mathrm{Mg} \mathrm{m}^{-3}, \mathrm{FW}=319.16$ for $\mathrm{C}_{14} \mathrm{H}_{11} \mathrm{BrN}_{2} \mathrm{O}_{2}$, $F(000)=640$. Yellow single crystal $\left(0.15 \times 0.10 \times 0.10 \mathrm{~mm}^{3}\right)$ of 22 was obtained by slow evaporation from methanol/chloroform (30/ 70) solution: monoclinic, space group $P 21 / n, a=5.4906(5) \AA$, $b=14.0619(7) \AA, c=12.9743(7) \AA, \alpha=90^{\circ}, \beta=94.431(3)^{\circ}, \gamma=90^{\circ}$, $V=998.73(12) \AA^{3}, Z=4, \delta($ calcd $)=1.345 \mathrm{Mg} \mathrm{m}^{-3}, F W=202.21$ for $\mathrm{C}_{11} \mathrm{H}_{10} \mathrm{~N}_{2} \mathrm{O}_{2}, F(000)=424$. Full crystallographic results have been deposited at the Cambridge Crystallographic Data Centre (CCDC888291, CCDC-912632 and CCDC-884533), UK, as Supplementary material [33]. The data were corrected for Lorentz and polarization effects and for empirical absorption correction [50]. The structure was solved by direct methods Shelx 86 [51] and refined using Shelx 93 [52] suite of programs.

\subsection{Biological assays}

\subsubsection{Preparation of recombinant human CK2 holoenzyme}

The preparation of the human recombinant CK2 holoenzyme was performed according to a protocol described previously [42]. For the expression of the $\alpha$-subunit (CSNK2A1) and $\beta$-subunit (CSNK2B) of the human protein kinase CK2 a pT7-7 expression system in Escherichia coli BL21 (DE3) was used. Newly transformed starter cultures were grown overnight at $37^{\circ} \mathrm{C}$ in LB-medium to the stationary phase. New medium was inoculated with the separate starter cultures for both subunits and cultivated until an $\mathrm{OD}_{500}$ of 0.6 was reached. Expression was induced by addition of IPTG $(1 \mathrm{mM}$ final concentration) and carried out at $30^{\circ} \mathrm{C}$ for $5-6 \mathrm{~h}$ for CSNK2A1 and at $37{ }^{\circ} \mathrm{C}$ for $3 \mathrm{~h}$ for CSNK2B. Cells were harvested by centrifugation $\left(6000 \times \mathrm{g}\right.$ for $10 \mathrm{~min}$ at $\left.4{ }^{\circ} \mathrm{C}\right)$ and disrupted by sonification (three times $30 \mathrm{~s}$ on ice). Preparations were then centrifuged to remove the cells debris and the bacterial extracts for both subunits were combined and purified by a three-column procedure. Fractions exhibiting CK2 activity were combined and analyzed by SDS-PAGE and Western Blot.

\subsubsection{Capillary electrophoresis based assay for the testing of} inhibitors of the human CK2

The recently established capillary electrophoresis CK2 activity assay was used for testing the inhibitors [42]. Therefore, $2 \mu \mathrm{L}$ of the dissolved inhibitors (stock solution in DMSO) were mixed with $78 \mu \mathrm{L}$ of CK2 supplemented kinase buffer which was composed of $1 \mu \mathrm{g}$ CK2 holoenzyme, $50 \mathrm{mM}$ Tris/ $\mathrm{HCl}$ (pH 7.5), $100 \mathrm{mM} \mathrm{NaCl}$, $10 \mathrm{mM} \mathrm{MgCl} 2$ and $1 \mathrm{mM}$ DTT. The reaction was initiated by the addition of $120 \mu \mathrm{L}$ assay buffer, which was composed of $25 \mathrm{mM}$ Tris/ $\mathrm{HCl}$ (pH 8.5), $150 \mathrm{mM} \mathrm{NaCl}, 5$ mM MgCl 2,1 mM DTT, $100 \mu \mathrm{M}$ ATP and $0.19 \mathrm{mM}$ of the substrate peptide RRRDDDSDDD. The reaction was carried out for $15 \mathrm{~min}$ at $37^{\circ} \mathrm{C}$ and stopped by the addition of $4 \mu \mathrm{L}$ EDTA $(0.5 \mathrm{M})$. Subsequently the reaction mixture was analyzed by a PA800 capillary electrophoresis from Beckman Coulter (Krefeld, Germany). Acetic acid ( $2 \mathrm{M}$, adjusted with conc. $\mathrm{HCl}$ to a $\mathrm{pH}$ of 2.0) was used as the electrolyte for electrophoretic separation. The separated substrate and product peptide were detected at $214 \mathrm{~nm}$ using a DAD-detector. Pure solvent was used as negative control $(0 \%$ inhibition), assays devoid of CK2 were used as positive control (100\% inhibition). For primary testing an inhibitor concentration of $10 \mu \mathrm{M}$ was used. Compounds that revealed at least $50 \%$ inhibition at $10 \mu \mathrm{M}$ were used for $\mathrm{IC}_{50}$ determinations. For the determination of $\mathrm{IC}_{50}$ inhibition was determined using nine inhibitor concentrations ranging from $0.001 \mu \mathrm{M}$ to $100 \mu \mathrm{M}$. $\mathrm{IC}_{50}$ values were calculated from the resulting dose-response curves.

\subsubsection{Cell culture}

The human leukemic cell lines U937, K562, MV-4-11 and Jurkat were grown in RPMI 1640 medium (Life Technology, France) supplemented with $10 \%$ fetal calf serum (FCS), antibiotics (100 U/ $\mathrm{mL}$ penicillin, $100 \mu \mathrm{g} / \mathrm{mL}$ streptomycin) and L-glutamine, (Eurobio, France) at $37{ }^{\circ} \mathrm{C}, 5 \% \mathrm{CO}_{2}$ in air. The toxicity of various molecules was also evaluated on non-activated, freshly isolated normal human peripheral blood mononuclear cells (PBMNC), as well as phytohemagglutinin ( $T$ lymphoproliferative agent) (PHA)-induced cells. PBMNC from blood of healthy volunteers were obtained following centrifugation on Ficoll gradient. Cells were then incubated in medium alone or induced to enter cell cycle by the addition of PHA (5 $\mu \mathrm{g} / \mathrm{mL}$, Murex Biotech Limited, Dartford, UK).

\subsubsection{Cytotoxicity test}

The MTS cell proliferation assay (Promega, France) is a colorimetric assay system, which measures the reduction of a tetrazolium component (MTS) into formazan produced by the mitochondria of viable cells. Cells were washed twice in PBS (Phosphate Buffer Saline) and plated in quadruplicate into microtiter-plate wells in $100 \mu \mathrm{L}$ culture media with or without our various compounds at increasing concentrations $(0,1,5,10,20$ and $50 \mu \mathrm{M}$ ) during 1,2 and 3 days. After $3 \mathrm{~h}$ of incubation at $37^{\circ} \mathrm{C}$ with $20 \mu \mathrm{L}$ MTS/well, the plates were read by using an ELISA microplate reader (Thermo, Electrocorporation) at $490 \mathrm{~nm}$ wavelength. The amount of color produced was directly proportional to the number of viable cells. The results are expressed as the concentrations inhibiting cell growth by $50 \%$ after a 3 days incubation period. The $50 \%$ cytotoxic concentrations $\left(\mathrm{CC}_{50}\right)$ were determined by linear regression analysis, expressed in $\mu \mathrm{M} \pm \mathrm{SD}$ (Microsoft Excel).

\subsection{Computational methods}

The geometries of the $\mathbf{1 f}$ and 1c compounds were optimized using the $a b$ initio quantum chemistry program Gaussian 03 and the HF/6-31G** basis set [53]. RESP (restraint electrostatic potential) atomic charges of both inhibitors were calculated to generate the corresponding force field parameters.

Molecular dynamics (MD) were performed by using the AMBER12 software package [54]. The crystal structure of the CK2/ CX-4945 complex (pdb: 3pe1) [48] was used as starting structure for the MD simulations; having removed the sulfate ions and water molecules, except those water molecules located within $5 \AA$ of the ligand. The CK2/1f complex was built in silico by superposing the central ring atoms of the ligand with the corresponding atoms of the CX-4945 compound in the CK2/CX-4945 complex. To build the $\mathrm{CK} 2 / \mathbf{1 c}$ complex two initial orientations of the ligand were chosen: one with the heterocyclic system orientated as in the 1f system and the other with the 1c A-ring sited at the position of the 1f C-ring, and vice versa. The complexes were immersed in an octahedral box of TIP3P water molecules using the Leap module, giving final systems of around 45,000 atoms. The systems were initially optimized and then gradually heated to $300 \mathrm{~K}$. Starting from these equilibrated structures $40 \mathrm{~ns}$ MD production runs were performed. All simulations were carried out at $1 \mathrm{~atm}$ and $300 \mathrm{~K}$, maintained with the Berendsen barostat and thermostat [55], using periodic boundary conditions and Ewald sums (grid spacing of $1 \AA$ ) for treating long range electrostatic interactions. The SHAKE algorithm was used to keep bonds involving $\mathrm{H}$ atoms at their equilibrium length, allowing the use of a 2 fs time step for the integration of Newton's equations. The ligand parameters were assigned with the general AMBER force field (GAFF) and the corresponding RESP charges with the Antechamber module of AMBER. The Amber99 force field parameters were used for all residues [56] excepted for the ligands. Computed energetic contributions of $\mathbf{1 f}$ and $\mathbf{1 c}$ corresponded to the electrostatic energy and Van der Waals contributions arising from bond, angle and dihedral terms in the force field. 
Calculations were performed using the MMPBSA.py method on 500 snapshots of the last 20 ns of the trajectories.

\section{Acknowledgments}

This publication was supported by a grant from Ligue Nationale contre le Cancer (Comité d'Aquitaine-Charentes, Bordeaux, France). Its content is solely the responsibility of the authors and does not necessarily represent the official views of the Ligue Nationale contre le Cancer.

\section{Appendix A. Supplementary data}

Supplementary data related to this article can be found at http:// dx.doi.org/10.1016/j.ejmech.2013.04.051.

\section{References}

[1] J.M. Chen, C. Gao, Q. Shi, B. Shan, Y.J. Lei, C.F. Dong, R. An, G.R. Wang, B.Y. Zhang, J. Han, X.P. Dong, Arch. Virol. 153 (2008) 1013-1020.

[2] G. Burnett, E.P. Kennedy, J. Biol. Chem. 211 (1954) 969-980.

[3] K. Ahmed, O.G. Issinger, K. Niefind, Mol. Cell. Biochem. 356 (2011) 1-3.

[4] F. Piazza, S. Manni, M. Ruzzene, L.A. Pinna, C. Gurrieri, G. Semenzato, Leukemia 26 (2012) 1174-1179.

[5] G. Lolli, L.A. Pinna, R. Battistutta, Chem. Biol. 7 (2012) 1158-1163.

[6] J. Bliesath, N. Huser, M. Omori, D. Bunag, C. Proffitt, N. Streiner, C. Ho, A. Siddiqui-Jain, S.E. O’Brien, J.K. Lim, D.M. Ryckman, K. Anderes, W.G. Rice, D. Drygin, Cancer Lett. 322 (2012) 113-118.

[7] Y. Zheng, H. Qin, S.J. Frank, L. Deng, D.W. Litchfield, A. Tefferi, A. Pardanani, F.T. Lin, J. Li, B. Sha, E.N. Benveniste, Blood 118 (2011) 156-166.

[8] E. Papinutto, A. Ranchio, G. Lolli, L.A. Pinna, R. Battistutta, J. Struct. Biol. 177 (2012) 382-391.

[9] J.H. Trembley, Z. Chen, G. Unger, J. Slaton, B.T. Kren, W.C. Van, K. Ahmed, Biofactors 36 (2010) 187-195.

[10] R. Prudent, C. Cochet, Chem. Biol. 16 (2009) 112-120.

[11] S. Sarno, E. Papinutto, C. Franchin, J. Bain, M. Elliott, F. Meggio, Z. Kazimierczuk, A. Orzeszko, G. Zanotti, R. Battistutta, L.A. Pinna, Curr. Top. Med. Chem. 11 (2011) 1340-1351.

[12] J. Kim, S.H. Kim, Arch. Pharm. Res. 35 (2012) 1293-1296.

[13] G. Campiani, S. Butini, C. Fattorusso, F. Trotta, S. Franceschina, M. De Angelis, K.S. Nielsen, PCT 2006, WO2006072608.

[14] G. Campiani, F. Aiello, M. Fabbrini, E. Morelli, A. Ramunno, S. Armaroli, V. Nacci, A. Garofalo, G. Greco, E. Novellino, G. Maga, S. Spadari, A. Bergamini, L. Ventura, B. Bongiovanni, M. Capozzi, F. Bolacchi, S. Marini, M. Coletta, G. Guiso, S. Caccia, J. Med. Chem. 44 (2001) 305-315.

[15] S. Schann, S. Mayer, S. Gardan, Eur. Patent 2007, EP1798233.

[16] J. Guillon, P. Grellier, M. Labaied, P. Sonnet, J.-M. Léger, R. Déprez-Poulain, I. Forfar-Bares, P. Dallemagne, N. Lemaître, F. Péhourcq, J. Rochette, C. Sergheraert, C. Jarry, J. Med. Chem. 47 (2004) 1997-2009.

[17] J. Guillon, I. Forfar, M. Mamani-Matsuda, V. Desplat, M. Saliège, D. Thiolat, S. Massip, A. Tabourier, J.-M. Léger, B. Dufaure, G. Haumont, C. Jarry, D. Mossalayi, Bioorg. Med. Chem. 15 (2007) 194-210.

[18] J. Guillon, I. Forfar, V. Desplat, S. Belisle-Fabre, D. Thiolat, S. Massip, H. Carrie, D. Mossalayi, C. Jarry, J. Enzyme Inhib. Med. Chem. 22 (2007) 541-549.

[19] J. Guillon, S. Moreau, E. Mouray, V. Sinou, I. Forfar, S. Belisle-Fabre, V. Desplat, P. Millet, D. Parzy, C. Jarry, P. Grellier, Bioorg. Med. Chem. 16 (2008) 9133-9144.

[20] J. Guillon, E. Mouray, S. Moreau, C. Mullié, I. Forfar, V. Desplat, S. Belisle-Fabre, F. Ravanello, A. Le-Naour, N. Pinaud, J.-M. Léger, G. Gosmann, C. Jarry, G. Déléris, P. Sonnet, P. Grellier, Eur. J. Med. Chem. 46 (2011) 2310-2326.

[21] J. Milne, K.D. Normington, M. Milburn, PCT 2006, WO2006094210.

[22] F. Grande, F. Aiello, O. De Grazia, A. Brizzi, A. Garofalo, N. Meamati, Bioorg. Med. Chem. 15 (2007) 288-294.

[23] V. Desplat, A. Geneste, M.-A. Begorre, S. Belisle Fabre, S. Brajot, S. Massip, D. Thiolat D. Mossalayi, C. Jarry, J. Guillon, J. Enzyme Inhib. Med. Chem. 23 (2008) 648-658.

[24] V. Desplat, S. Moreau, A. Gay, S. Belisle-Fabre, D. Thiolat, S. Massip, D. Mossalayi, C. Jarry, J. Guillon, J. Enzyme Inhib. Med. Chem. 25 (2010) 204-215.
[25] V. Desplat, S. Moreau, S. Belisle-Fabre, D. Thiolat, J. Uranga, R. Lucas, S. Massip L. de Moor, C. Jarry, D. Mossalayi, P. Sonnet, G. Déléris, J. Guillon, J. Enzyme Inhib. Med. Chem. 26 (2011) 657-667.

[26] E. Röder, H. Wiedenfeld, T. Bourauel, Liebigs Ann. Chem. 12 (1987) 1117-1119

[27] Z.-L. Zhou, S.M. Kher, S.X. Cai, E.R. Whittemore, S.A. Espitia, J.E. Hawkinson, M. Tran, R.M. Woodward, E. Weber, J.F.W. Keana, Bioorg. Med. Chem. 11 (2003) 1769-1780.

[28] L. Guandalini, E. Martini, M.N. Romanelli, F. Dallatomasina, PCT 2008, WO2008012852A1.

[29] J. Guillon, A. Alsaidi, P. Dallemagne, S. Rault, Pharm. Pharmacol. Commun. 4 (1998) 231-235.

[30] S. Yoo, S. Lee, Synlett 7 (1990) 419-420.

[31] S. Alleca, P. Corona, M. Loriga, G. Paglietti, R. Loddo, V. Mascia, B. Busonera, P. La Colla, Farmaco 58 (2003) 639-650.

[32] J. Ahman, S.L. Buchwald, Tetrahedron Lett. 38 (1997) 6363-6366.

33] Supplementary X-ray crystallographic data: Cambridge Crystallographic Data Centre, University Chemical Lab, Lensfield Road, Cambridge, CB2 1EW, UK; Email: deposit@chemcrys.cam.ac.uk.

[34] C. McFarland, D.A. Vicic, A.K. Debnath, Synthesis 5 (2006) 807-812.

[35] J.M. Lalonde, M.A. Elban, J.R. Courter, A. Sugawara, T. Soeta, N. Madani, A.M. Princiotto, Y.D. Kwon, P.D. Kwong, A. Schön, E. Freire, J. Sodroski, A.B. Smith III, Bioorg. Med. Chem. 19 (2011) 91-101.

[36] J. Guillon, R. Reynolds, J.-M. Léger, M.-A. Guié, S. Massip, P. Dallemagne, C. Jarry, J. Enzyme Inhib. Med. Chem. 19 (2004) 489-495.

[37] O. Lavastre, S. Cabioch, P.H. Dixneuf, J. Vohlidal, Tetrahedron 53 (1997) 7595-7604.

[38] M. Erdélyi, A. Gogoll, J. Org. Chem. 66 (2001) 4165-4169.

[39] G. Galambos, P. Csokasi, C. Szantay Jr., C. Szantay, Liebigs Ann./Recueil (1997) 1969-1978.

[40] L.T. Liu, T.-T. Yuan, H.-H. Liu, S.-F. Chen, Y.-T. Wu, Bioorg. Med. Chem. Lett. 17 (2007) 6373-6377.

[41] I. Ermakova, B. Boldyreff, O.G. Issinger, K. Niefind, J. Mol. Biol. 330 (2003) 925-934.

[42] A. Gratz, C. Götz, J. Jose, Electrophoresis 31 (2010) 634-640.

[43] C. Hundsdörfer, H.-J. Hemmerling, C. Götz, F. Totzke, P. Bednarski, M. Le Borgne, J. Jose, Bioorg. Med. Chem. 20 (2012) 2282-2289.

[44] http://www.molinspiration.com/cgi-bin/properties, (accessed 20.03.13).

[45] C.A. Lipinski, F. Lombardo, B.W. Dominy, P.J. Feeney, Adv. Drug Del. Rev. 46 (2001) 3-26.

[46] D.E. Clark, J. Pharm. Sci. 88 (1999) 807-814

[47] P. Ertl, B. Rohde, P. Selzer, J. Med. Chem. 43 (2000) 3714-3717.

[48] R. Battistutta, G. Cozza, F. Pierre, E. Papinutto, G. Lolli, S. Sarno, S.E. O’Brien, A. Siddiqui-Jain, M. Haddach, K. Anderes, D.M. Ryckman, F. Meggio, L.A. Pinna, Biochemistry 50 (2011) 8478-8488.

[49] H. Liu, X. Wang, J. Wang, J. Wang, Y. Li, L. Yang, G. Li, Int. J. Mol. Sci. 12 (2011) 7004-7021.

[50] A.C.T. North, D.C. Phillips, F.S. Mathews, Acta Crystallogr. A24 (1968) 351.

[51] G.M. Sheldrick, C. Kröger, R. Goddard, SHELX 86 in Crystallographic Computing 3, Oxford University Press, New-York, 1985, p. 175.

[52] G.M. Sheldrick, SHELX 93, Program for the Refinement of the Crystal Structures, University of Göttingen, Germany, 1993.

[53] M.J. Frisch, G.W. Trucks, H.B. Schlegel, G.E. Scuseria, M.A. Robb, J.R. Cheeseman, J.A. Montgomery Jr., T. Vreven, K.N. Kudin, J.C. Burant, J.M. Millam, S.S. Iyengar, J. Tomasi, V. Barone, B. Mennucci, M. Cossi, G. Scalmani, N. Rega, G.A. Petersson, H. Nakatsuji, M. Hada, M. Ehara, K. Toyota, R. Fukuda, J. Hasegawa, M. Ishida, T. Nakajima, Y. Honda, O. Kitao, H. Nakai, M. Klene, X. Li, J.E. Knox, H.P. Hratchian, J.B. Cross, V. Bakken, C. Adamo, J. Jaramillo, R. Gomperts, R.E. Stratmann, O. Yazyev, A.J. Austin, R. Cammi, C. Pomelli, J.W. Ochterski, P.Y. Ayala, K. Morokuma, G.A. Voth, P. Salvador, J.J. Dannenberg, V.G. Zakrzewski, S. Dapprich, A.D. Daniels, M.C. Strain, O. Farkas, D.K. Malick, A.D. Rabuck, K. Raghavachari, J.B. Foresman, J.V. Ortiz, Q. Cui, A.G. Baboul, S. Clifford, J. Cioslowski, B.B. Stefanov, G. Liu, A. Liashenko, P. Piskorz, I. Komaromi, R.L. Martin, D.J. Fox, T. Keith, M.A. AlLaham, C.Y. Peng, A. Nanayakkara, M. Challacombe, P.M.W. Gill, B. Johnson, W. Chen, M.W. Wong, C. Gonzalez, J.A. Pople, Gaussian 03, Revision C.02, Gaussian, Inc., Wallingford CT, 2004.

[54] D.A. Pearlman, D. Case, J.W. Caldwell, W.S. Ross, T.E. Cheatham III, S. DeBolt D. Ferguson, G. Seibel, P. Kollman, Comput. Phys. Commun. 91 (1995) 1-41.

[55] H.J.C. Berendsen, J.P.M. Postma, W.F. Van Gunsteren, A. DiNola, J.R. Haak, J. Chem. Phys. 81 (1984) 3684-3690.

[56] T.E. Cheatham III, P. Cieplak, P.A. Kollman, J. Biomol. Struct. Dynam. 16 (1999) $845-862$ 